\title{
MECANISMOS DE AÇÃO DO PALMITATO \\ COMO MODULADOR DA NADPH OXIDASE EM \\ ILHOTAS PANCREÁTICAS E LINHAGEM INS-1E
}

Tese apresentada ao Programa de PósGraduação em Fisiologia e Biofísica do Instituto de Ciências Biomédicas da Universidade de São Paulo, para obtenção do Título de Doutor em Ciências. 


\section{MECANISMOS DE AÇÃO DO PALMITATO COMO MODULADOR DA NADPH OXIDASE EM ILHOTAS PANCREÁTICAS E LINHAGEM INS-1E}

Tese apresentada ao Programa de PósGraduação em Fisiologia e Biofísica do Instituto de Ciências Biomédicas da Universidade de São Paulo, para obtenção do Título de Doutor em Ciências.

Área de concentração: Fisiologia Humana

Orientador: Prof. Dr. Angelo Rafael Carpinelli

São Paulo

2010 
DADOS DE CATALOGAÇÃO NA PUBLICAÇÃO (CIP)

Serviço de Biblioteca e Informação Biomédica do

Instituto de Ciências Biomédicas da Universidade de São Paulo

reprodução não autorizada pelo autor

Graciano, Maria Fernanda Rodrigues.

Mecanismos de ação do palmitato como modulador da NADPH oxidase em ilhotas pancreáticas e linhagem INS-1E / Maria Fernanda Rodrigues Graciano. -- São Paulo, 2010.

Orientador: Angelo Rafael Carpinelli.

Tese (Doutorado) - Universidade de São Paulo. Instituto de Ciências Biomédicas. Departamento de Fisiologia e Biofísica. Área de concentração: Fisiologia Humana. Linha de pesquisa: Secreção de insulina.

Versão do título para o inglês: Mechanisms of palmitate action as a modulator of NADPH oxidase in pancreatic islets and INS-1E cells.

Descritores: 1. Ilhotas de Langerhans 2. Ácidos graxos 3. Insulina 4. Ratos I. Carpinelli, Angelo Rafael II. Universidade de São Paulo. Instituto de Ciências Biomédicas. Programa de Pós-Graduação em Fisiologia Humana III. Título. 


\section{UNIVERSIDADE DE SÃO PAULO \\ INSTITUTO DE CIÊNCIAS BIOMÉDICAS}

Candidato(a): $\quad$ Maria Fernanda Rodrigues Graciano.

Título da Tese: $\quad$ Mecanismos de ação do palmitato como modulador da NADPH oxidase em ilhotas pancreáticas e linhagem INS-1E.

Orientador(a): $\quad$ Angelo Rafael Carpinelli.

A Comissão Julgadora dos trabalhos de Defesa da Tese de Doutorado, em sessão pública realizada a ..................., considerou

\section{( ) Aprovado(a)}

( ) Reprovado(a)

Examinador(a): Assinatura: .

Nome:

Instituição:

Examinador(a): Assinatura:

Nome:

Instituição:

Examinador(a): Assinatura:

Nome:

Instituição:

Examinador(a): Assinatura:

Nome:

Instituição:

Presidente: Assinatura:

Nome:

Instituição: 


\section{UNIVERSIDADE DE SÃO PAULO INSTITUTO DE CIÊNCIAS BIOMÉDICAS}

\section{Certificado}

Certificamos que o protocolo registrado sob $\mathrm{n}^{\circ} \mathbf{0 3 1}$ nas fls. $\mathbf{3 0}$ do livro $\mathbf{2}$ para uso de animais em experimentação, sob a responsabilidade de Angelo Rafael Carpinelli, Coordenador(a) da Linha de Pesquisa "Mecanismos de ação do palmitato como modulador da NAD(P)H oxidase em ithotas pancreáticas" do qual participou(aram) o(s) alunos Maria Fernanda Rodrigues Graciano e os pesquisadores Aparecida Emiko Hirata, Daniela Morgan, Eduardo Rebelato Lopes de Oliveira, Tatiane Cristina de Araújo Nogueira, está de acordo com os Principios Éticos de Experimentação Animal adotado pelo Colégio Brasileiro de Experimentação Animal (COBEA) e foi aprovado pela COMISSÃO DE ÉTICA EM EXPERIMENTAÇÃO ANIMAL (CEEA) em 23.03.2006.

São Paulo, 23 de março de 2006.

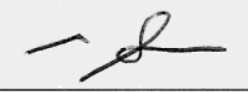

Profa. Dra. Marília C.L.Seelaender Coordenadora -CEEA - ICB/USP
Profa. Dra. Patrícia Castelucci Secretária Suplente CEEA - ICB/USP 


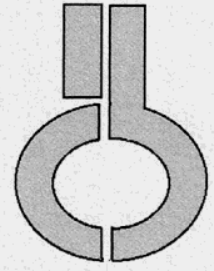

UNIVERSIDADE DE SÃo PAULO

\section{INSIITUTO DE CIÊNCIAS BIOMÉDICAS}

Cidade Universitária "Armando de Salles Oliveira"

Av. Prof. Lineu Prestes, 2415 - cep. 05508-000 São Paulo, SP - Brasil

Telefone :(55) (011) 3091.7733 - telefax : (55) (011) 30917438

e-mail: cep@icb.usp.br

\section{Of.CEUA.40.10}

NOSC/mcgn

São Paulo, 23 de julho de 2010.

\section{REF.: Protocolo $\mathbf{n}^{0} 031 / 06$.}

"Mecanismos de ação do palmitato como modulador da $N A D(P) H$ oxidase em ilhotas pancreáticas"

Prezado Professor,

Informo que a sua licença para uso de animais em experimentação, constante no protocolo em epígrafe, foi prorrogada até 23.03.2012.

Reitero que havendo alteração de metodologia e inserção de novos alunos ao projeto de pesquisa vinculado à referida licença a CEUAIICB deverá ser informada.

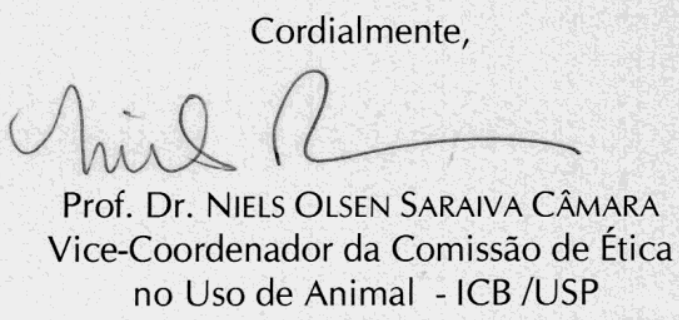

Ilmo.Sr.

Prof Dr. ANGELO RAFAel CARPINELLI

Departamento de Fisiologia e Biofiscica

Instituto de Ciências Biomédicas - USP 
Ao amor, confiança e incentivo incondicionais de meus pais, Vânia e José Roberto.

Ao amor, companheirismo e perseverança incondicionais em nosso perene caminhar, Mauro.

Razões do meu viver... 


\section{AGRADECIMENTOS}

Primeiramente, a quem me acolheu em seu laboratório e me deu amplas oportunidades em minha formação profissional e muito mais do que isso, em meu "currículo oculto", já que me estimulou para que eu acreditasse em meu potencial e persistisse em cada etapa. Obrigada prof. Angelo pelo carinho, amparo, paciência e incessante incentivo desde a iniciação científica!

Aos meus pais, pelo imenso amparo, confiança, amor e estímulo que me dão em cada etapa de minha vida e que fazem ampliar a fé na vida e a coragem no futuro. Vocês são os sustentáculos de minha existência. Logo, aos meus sustentáculos emocionais: minha irmã Vanessa, avó Anna, tia Liliane, tia Márcia, tio Carlos, tia Sandra, tio Ordival, primos Breno e Karina, minhas tias-avós Nanci, Elza, Irene, e também aos que estão do lado de lá: vó Penha, vô Hugo, vô Ricardo, tio Gilberto e tia Elisa. À família que me acolheu com enorme carinho e cumplicidade: aos pais do Mauro, Ídolo e Maria Inês, e aos meus indescritíveis cunhados, Maurício, Maria, Marcelo e Cristiane. Vocês todos estão eternamente em meu coração.

Aos antigos entes do laboratório de "Fisiologia da Secreção de Insulina", mas sempre presentes em boas Cembranças e ensinamentos: Tatiane, Henriette, Daniela, Cecília, Eliane, Helena, Esther, André, Mariane, Fernanda, Aline. Vocês fizeram parte dos meus primeiros passos nessa vida científica e também de muitas 6oas conversas e imenso incentivo.

Aos atuais entes do Laboratório, Maíra, Daniel, Eloísa, Camila, Gabriela, Laila, Eduardo. Aprendo muito com cada um de vocês, principalmente a importância e valor da verdadeira amizade e a fortalecer os laços de afeto através do incessante trabalho por compreender e aceitar um ao outro, através de inúmeros desafios. De tudo, pretendo levar comigo a amizade que ampara, suplanta qualquer tipo de dificuldade e que permite com que não tenhamos medo de expor o que realmente somos, amamos e aspiramos.

Aos professores que são os sustentáculos da minha formação e que sempre me auxiliaram, abrindo seus laboratórios para meus experimentos, sanar dúvidas, 6uscar construtivas sugestões, ou mesmo para amparar-me frente às dificuldades científicas, bem como: profa. Carla, profa. Silvana, profa. Andréa, prof. 
Rui, prof. Fernando e prof. Britto do Instituto de Ciências Biomédicas I; à profa Mari do Instituto de Química e à profa. Emiko da Escola Paulista de Medicina.

À Marlene, pela organização, amor e paciência com toda a criançada, grupo no qual com certeza me incluo, organizando todas as bagunças que cotidianamente fazemos...

Ao Zé Carlos, com suas passagens rápidas pelo laboratório, mas não menos carinhoso conosco.

Ao Adílson, pela alegria contagiante, conversas sempre agradáveis e ótima energia.

À Zizi Medonça do Instituto de Química, pela convivência rápida, mas infinita atenção e afeto ao me ensinar o cultivo de células.

À Tatiana do prof. Rui, pelos enormes auxílios e agradáveis conversas durante o almoço.

Ao Bo6, Vilson, Maria Alice, Jaqueline, Teca, Elisa, Claudio e Miguel, pois sem o trabalho e a alegria de vocês tudo seria muito mais difícil! Ao Zé Maria e Itamar, pelos constantes e importantíssimos auxílios frente às dificuldades na pós-graduação ou no indesvendável mundo da informática.

Aos amigos vizinhos de laboratório antigos e atuais, com os quais dividi ótimas conversas e muito me fazem ampliar meus horizontes: Jarlei e Thaís do prof. Rui; Camilo da profa. Silvana; Anderson e Mário da profa. Carla; Thaísa da profa. Andréa; Erika, Cecília e Caroline do prof. Britto.

Aos professores do Departamento de Fisiologia e Biofísica do ICB/USP e da Veterinária/USP que participaram ativamente da minha formação e são exemplos de amor ao ensino e pesquisa.

Aos meus amigos da Veterinária/USP, com os quais mantenho laços estreitos de cumplicidade e carinho, estando perto ou distante: Arine ("Afrodite"), Paula ("Muzzarela"), Alexandre ("Traveko"), Fábio (“Ponstan"), Marcelo (“Fe6ém”), Rodrigo ("He6e"), Luiz (“Artefato"), Bruno ("Signal”), Marcelo ("Flan”), Daniel("Sujo"). Dividimos alegrias e tristezas desde o início da faculdade e isso muito nos fortalece.

Aे FAPESP, CAPES e CNPq, pelo apoio financeiro. 
“O caminho da vida pode ser o da liberdade e da beleza, porém nos extraviamos.

Criamos a época da velocidade, mas nos sentimos enclausurados dentro dela. A máquina, que produz abundância, tem-nos deixado em penúria.

Nossos conhecimentos fizeram-nos céticos; nossa inteligência, empedernidos e cruéis. Pensamos em demasia e sentimos bem pouco.

Mais do que de máquinas, precisamos de humanidade. Mais do que de inteligência, precisamos de afeição e doçura. Sem essas virtudes, a vida será de violência e tudo será perdido."

(Trecho do último discurso do filme "O Grande Ditador")

\section{Charles Chaplin}




\section{RESUMO}

GRACIANO, M. F. R. Mecanismos de ação do palmitato como modulador da NADPH oxidase em ilhotas pancreáticas e linhagem INS-1E. 2010. 118 f. Tese (Doutorado em Fisiologia) - Instituto de Ciências Biomédicas, Universidade de São Paulo, São Paulo, 2010.

O complexo NADPH oxidase participa da secreção de insulina estimulada pela glicose e da produção de superóxido nas ilhotas pancreáticas. Nesse estudo, avaliamos o efeito do ácido palmítico na produção de superóxido e secreção de insulina por ilhotas pancreáticas de ratas e linhagem INS-1E, bem como os mecanismos envolvidos. Ambas foram incubadas durante $1 \mathrm{~h}$ na presença de $1 \mathrm{mM}$ palmitato, $1 \%$ albumina livre de ácidos graxos, em concentrações de alta $(10$ ou $16,7 \mathrm{mM})$ e baixa glicose $(2,8$ ou $5,6 \mathrm{mM})$ na presença dos inibidores da NADPH oxidase (DPI, difenileno-iodônio), PKC (calphostin C) e da carnitina palmitoil transferase-I (CPT-I) (etomoxir). O conteúdo de superóxido foi determinado pelo método da hidroetidina. O palmitato aumentou a produção de superóxido de maneira mais proeminente em baixa do que em alta glicose. Tal efeito estimulador do palmitato mostrou-se dependente da ativação da PKC e da NADPH oxidase. A oxidação do palmitato contribuiu para a indução de superóxido na presença do ácido graxo em 5,6 mM glicose. O ácido graxo causou a translocação da $\mathrm{p} 47^{\mathrm{PHOX}}$ para a membrana plasmática, como demonstrado por imunoistoquímica, um processo indicativo da ativação do complexo enzimático. A exposição de ilhotas ao palmitato causou o aumento do conteúdo proteico da $447^{\text {PHOX }}$ e do RNAm da $222^{\text {PHOX }}$, gp91 ${ }^{\text {PHOX }}, \mathrm{p} 47^{\text {PHOX }}$, próinsulina e do GPR40. A estimulação da secreção de insulina pelo ácido graxo na presença de alta glicose foi reduzida através do inibidor da NADPH oxidase e também pela inibição da expressão do GPR40 por RNA de interferência. Também, a inibida expressão do GPR40 reduziu a produção de superóxido induzida pelo palmitato nas células INS-1E. Concluímos que a NADPH oxidase é uma importante fonte de superóxido em ilhotas pancreáticas e na linhagem INS-1E. A atividade da NADPH oxidase e a sinalização via GPR40 são mecanismos envolvidos no controle da secreção de insulina estimulada pelo palmitato.

Palavras-chave: Ilhota pancreática. Palmitato. Ânion superóxido. Secreção de insulina. NADPH oxidase. GPR40. 


\begin{abstract}
GRACIANO, M. F. R. Mechanisms of palmitate action as a modulator of NADPH oxidase in pancreatic islets and INS-1E cells. 2010. $118 \mathrm{p}$. Ph. D. thesis (Physiology) Instituto de Ciências Biomédicas, Universidade de São Paulo, São Paulo, 2010.
\end{abstract}

The NADPH oxidase complex is involved in the glucose-stimulated insulin secretion (GSIS) and the superoxide production in pancreatic islets. In this study, we examined the effect of palmitic acid on superoxide production and insulin secretion by rat pancreatic islets and INS$1 \mathrm{E}$ cells and the mechanisms involved in those processes. Rat pancreatic islets and cells were incubated during $1 \mathrm{~h}$ with $1 \mathrm{mM}$ palmitate, $1 \%$ fatty acid free-albumin, high (10 or $16.7 \mathrm{mM})$ or low glucose ( 2.8 or $5.6 \mathrm{mM}$ ) concentrations and in the presence of inhibitors of NADPH oxidase (DPI diphenyleneiodonium), PKC (calphostin C) and carnitine palmitoyl transferase-I (CPT-I) (etomoxir). Superoxide content was determined by hydroethidine assays. Palmitate increased superoxide production more efficiently in low than in high glucose concentration. That stimulatory effect of palmitate was dependent on the activation of PKC and NADPH oxidase. Palmitic acid oxidation was demonstrated to contribute to the fatty acid induction of superoxide production in the presence of $5.6 \mathrm{mM}$ glucose. In fact, as shown by immunohistochemistry, palmitate caused $\mathrm{p} 47^{\mathrm{PHOX}}$ translocation to the plasma membrane, a process associated with the activation of the enzymatic complex. Exposure to palmitate for 1 $\mathrm{h}$ up-regulated the protein content of $\mathrm{p} 47^{\mathrm{PHOX}}$ and the mRNA levels of $\mathrm{p} 22^{\mathrm{PHOX}}$, gp91 ${ }^{\text {PHOX }}$, $\mathrm{p} 47^{\mathrm{PHOX}}$, proinsulin and the GPR40. Fatty acid stimulation of insulin secretion in the presence of a high glucose concentration was reduced by the inhibition of NADPH oxidase activity and by the inhibition of GPR40 expression by a small interference RNA. In addition, the downregulation of GPR40 reduced the superoxide production induced by palmitate in INS-1E cells. In conclusion, NADPH oxidase is an important source of palmitate-induced superoxide production in pancreatic islets and the activity of NADPH oxidase and GPR40 signaling are involved in the control of insulin secretion by palmitate.

Key Words: Pancreatic islets. Palmitate. Superoxide anion. Insulin secretion. NADPH oxidase. GPR40. 


\section{LISTA DE ABREVIATURAS E SIGLAS}

$\mathrm{AC}$ :

adenilato ciclase

Acil-CoA:

acil-coenzima A

AGLs:

ácidos graxos livres

AIR:

região auto inibitória

AMPc:

adenosina monofosfato cíclico

AS:

antisense

ATP:

adenosina trifosfato

BSA:

albumina sérica bovina

$\mathrm{C}$ :

controle

Calp:

calphostin C (inibidor de PKC)

CCDV:

canais de cálcio dependentes de voltagem

cDNA:

ácido desoxirribocleico complementar

CPT-I:

carnitina-palmitoil transferase I

DAG:

diacilgicerol

DHE:

dihidroetidina

DNA:

ácido desoxirribonucleico

DPI:

difenileno-iodônio

DTT:

ditiotreitol

EROs:

espécies reativas de oxigênio

$\mathrm{EH}$ :

hidroetidina

EPM:

erro padrão da média

Eto:

etomoxir (inibidor da CPT-I)

FACS:

"fluorescente activated cell sorter"

FAD: flavina-adenina dinucleotídeo

GDP: guanosina difosfato

GTP:

guanosina trifosfato

GIP:

glucose-dependent insulinotropic polypeptide

GLP-1:

glucagon-like-peptide

GPR40:

$G$ protein coupled receptor

GSH:

glutationa reduzida

GSSG:

glutationa oxidada 
GTP:

IP:

$\mathrm{IP}_{3}$ :

$\mathrm{K}_{\mathrm{ATP}}$ :

KDa:

$\mathrm{KO}$ :

LC-CoA:

NADPH:

NF- $\kappa B$ :

NOX:

NOXA:

NOXO:

PB:

PBS:

Palm:

PEG:

$\mathrm{PIP}_{2}$ :

PKA:

PKC:

PLC:

PMSF

PRR:

RE:

RNA:

RNAi:

SDS-PAGE:

SFB:

SOD: guanosina trifosfato

iodeto de propídeo

inositol-trifosfato

canais de potássio sensíveis ao ATP

Kilodaltons

knock out

cadeia longa de acil-coenzima A

nicotinamida adenina dinucleotídeo fosfato

fator nuclear kappa B

NADPH oxidases

ativador de NOX

organizador de NOX

tampão fosfato $0,1 \mathrm{M}$

tampão salina fosfato

palmitato

polietilenoglicol

fosfatidilinositol 4,5-bifosfato

proteína quinase $\mathrm{A}$

proteína quinase $\mathrm{C}$

fosfolipase $\mathrm{C}$

fenilmetilsulfonil fluoreto

região rica em prolina

retículo endoplasmático

ácido ribonucleico

RNA de interferência

eletroforese em gel de poliacrilamida-dodecil sulfato de sódio soro fetal bovino

superóxido dismutase 


\section{SUMÁRIO}

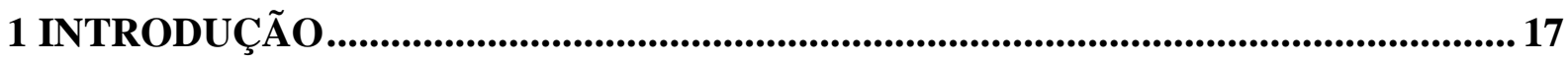

1.1 Mecanismos de secreção de insulina mediados pela glicose ...................................... 17

1.2 Ações dos ácidos graxos na ilhota pancreática............................................................ 18

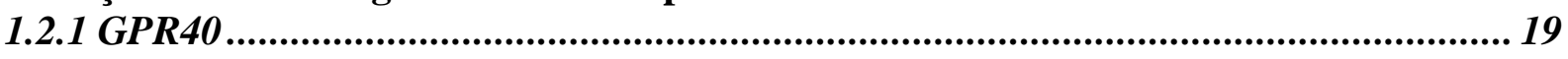

1.3 Espécies reativas de oxigênio no pâncreas endócrino ............................................... 26

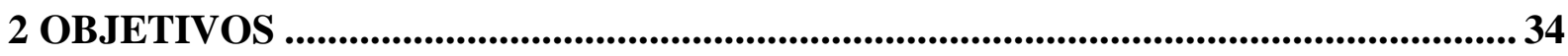

3 MATERIAIS E MÉTODOS ............................................................................... 35

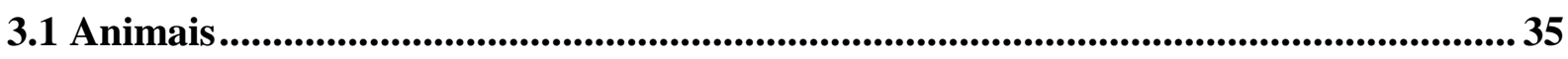

3.2 Isolamento das ilhotas de Langerhans.......................................................................... 35

3.3 Isolamento de neutrófilos peritoneais ................................................................ 36

3.4 Cultivo celular ......................................................................................................... 36

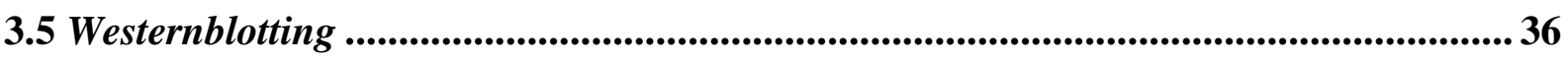

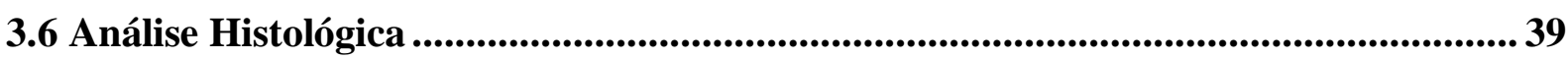

3.6.1 Fixação e crioproteção do tecido pancreático ........................................................... 39

3.6.2 Fixação e crioproteção das ilhotas pancreáticas .......................................................... 39

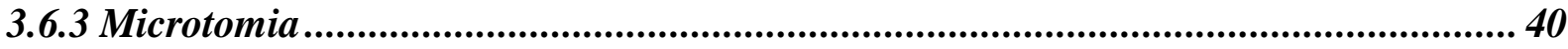

3.6.4 Imunofluorescência...................................................................................................... 40

3.7 Análise do conteúdo de ânion superóxido ..............................................................40

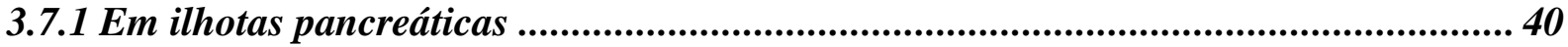

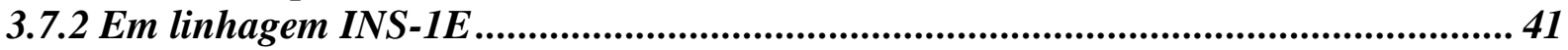

3.8 Análise da expressão gênica ...................................................................................42

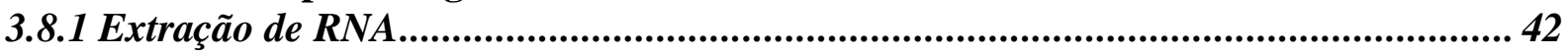

3.8.2 RT-PCR (Reação em Cadeia da Polimerase-Transcrição Reversa) em tempo real .. 42

3.8.3 Cálculo da eficiência dos primers na RT-PCR em tempo real.................................. 44

3.9 Secreção estática de insulina ...............................................................................4 47

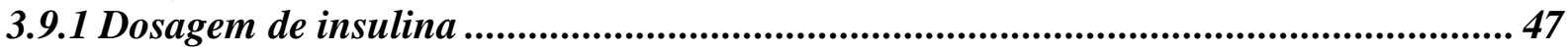

3.10 RNA de interferência para o GPR40 ...................................................................... 48

3.10.1 Transfecção da linhagem INS-1E com RNAi..................................................... 49

3.11 Análise da integridade de membrana da linhagem INS-1E.................................49

3.12 Análise da fragmentação de DNA da linhagem INS-1E ...................................50

3.13 Análise estatística ..................................................................................................................... 50

4 RESULTADOS E DISCUSSÃO ............................................................................. 51

4.1 Avaliação da distribuição histológica do GPR40 e da p47 ${ }^{\mathrm{PHOX}}$ no pâncreas endócrino 52

4.2 Avaliação do conteúdo de ânion superóxido nas ilhotas pancreáticas isoladas .......... 55

4.2.1 Conteúdo de superóxido na presença de palmitato e DPI .......................................... 55

4.2.2 Conteúdo de superóxido na presença de palmitato e calphostin C..............................61

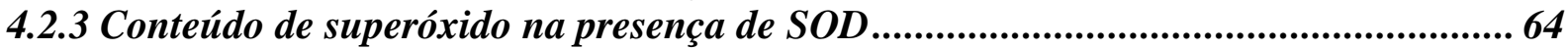


4.3 Avaliação da secreção estática de insulina

4.4 Avaliação da translocação da 47 $^{\mathrm{PHOx}}$ para a membrana plasmática em ilhotas pancreáticas.

4.5 Avaliação da expressão proteica e gênica do GPR40 ................................................. 71

4.6 Avaliação da expressão, fosforilação e translocação da PKC..................................... 72

4.7 Avaliação da expressão gênica da pró-insulina e da glicoquinase................................ 78

4.8 Avaliação da expressão proteica e gênica dos componentes da NADPH oxidase ...... 78

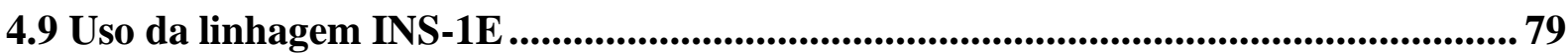

4.9.1 Avaliação dos componentes da NADPH oxidase em linhagem INS-1E .................... 79

4.9.2 Avaliação do conteúdo de superóxido em linhagem INS-1E na presença de palmitato,

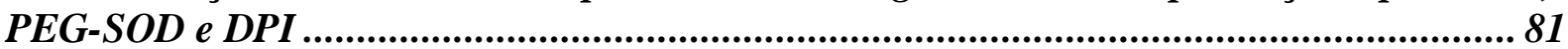

4.9.3 Avaliação do bloqueio da expressão do GPR40 por RNAi......................................... 84

4.9.4 Avaliação do conteúdo de superóxido em linhagem INS-1E após inibição da expressão do GPR40 ....................................................................................................... 87

4.9.5 Avaliação da secreção de insulina em linhagem INS-1E após inibição da expressão

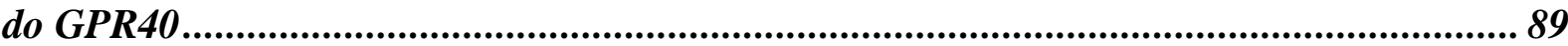

4.9.6 Avaliação da secreção de insulina em linhagem INS-1E com o agonista do GPR40. 92

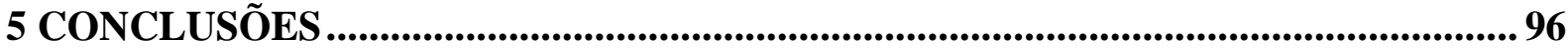

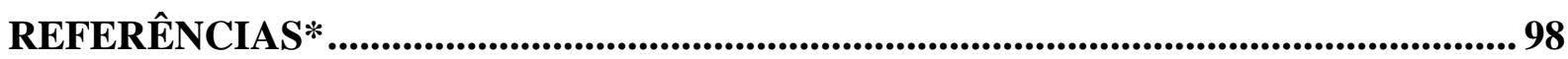

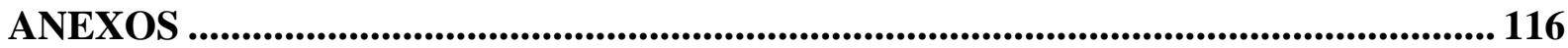

ANEXO A - Trabalho referente ao estudo desenvolvido durante o doutorado............. 116

ANEXO B - Trabalho referente ao estudo desenvolvido durante a Iniciação Científica e início do doutorado ............................................................................................... 117

ANEXO C - Trabalhos publicados em colaboração .................................................. 118 


\section{INTRODUÇÃO}

\subsection{Mecanismos de secreção de insulina mediados pela glicose}

A insulina é o hormônio anabólico produzido pelas células beta pancreáticas e tem como principal secretagogo a glicose plasmática. Regula a homeostase da glicose, reduzindo sua produção hepática, aumentando a sua captação periférica e diminuindo a utilização de substratos alternativos, principalmente no tecido muscular e adiposo.

O metabolismo da glicose nas células beta da ilhota aumenta a relação ATP/ADP, que causa o fechamento dos canais de potássio sensíveis ao ATP $\left(\mathrm{K}_{\mathrm{ATP}}\right)$, despolarizando a membrana plasmática pela inibição do efluxo de potássio e ativando os canais de cálcio dependentes de voltagem (CCDV). Os mecanismos que contribuem para a regulação da secreção de insulina estimulada pela glicose podem ser independentes da ativação dos $\mathrm{K}_{\mathrm{ATP}} \mathrm{e}$ dependentes do cálcio (GEMBAL; GILON; HENQUIN, 1992), ou independentes de ambos (KOMATSU et al., 1995).

Como mecanismo participante do processo secretório da insulina, é observado que a estimulação das células beta pela glicose leva à ativação de diferentes isoformas de fosfolipase C (PLC), que por sua vez, promovem a hidrólise de fosfolípides de membrana gerando inositol-trifosfato $\left(\mathrm{IP}_{3}\right)$ e diacilglicerol (DAG). O $\mathrm{IP}_{3}$ liberado provoca a abertura dos canais de cálcio localizados na membrana do retículo endoplasmático, mobilizando cálcio do interior da organela para o citoplasma e aumentando a concentração deste íon no citossol. O DAG permanece na membrana e, juntamente com o íon cálcio, ativa diversas isoformas de proteína quinase C (PKC) (JONES; PERSAUD; HOWELL, 1992). Além disso, o DAG aumenta a concentração de cálcio intracelular, ativando canais de cálcio sensíveis à voltagem presentes na membrana plasmática, aumentando, portanto, a passagem deste cátion do meio extracelular para o intracelular (BEST; DUNLOP; MALAISSE, 1984; SCHREY e MONTAGUE, 1983).

A PKC fosforila e ativa os sistemas de microtúbulos e microfilamentos responsáveis pela translocação dos grânulos de insulina para as proximidades da membrana plasmática, favorecendo a exocitose (DEENEY et al., 1996). A PKC é também capaz de ativar a adenilato ciclase (AC) com consequente aumento do conteúdo intracelular de monofosfato de adenosina cíclico (AMPc) (HUGHES et al., 1992). A metabolização da glicose nas células beta ativa também a AC, a qual catalisa a formação AMPc que, por sua vez, propicia a ativação da 
proteína quinase A (PKA). Esta, da mesma forma que a PKC, fosforila proteínas envolvidas no processo de exocitose dos grânulos de insulina.

Inúmeros outros mecanismos intracelulares são ativados pela glicose nas células beta e culminam com a formação de compostos ativos como prostaglandinas, ácido araquidônico e seus derivados, como o 12-HETE (derivado do ácido araquidônico produzido pela 12lipoxigenase), participando do processo de secreção de insulina (TURK; WOLF; MCDANIEL, 1987).

\subsection{Ações dos ácidos graxos na ilhota pancreática}

A exposição de ilhotas isoladas aos AGLs (ácidos graxos livres) agudamente potencializa a secreção de insulina induzida pela glicose, o que está relacionado ao comprimento da cadeia e ao grau de insaturação desses ácidos graxos (OPARA et al., 1994). Particularmente, os ácidos graxos de cadeia longa, como o palmitato, potencializam de maneira mais efetiva a secreção de insulina induzida pela glicose. Porém, em tratamentos mais longos, ilhotas de ratos submetidos a dietas ricas em ácidos graxos saturados (banha de porco) apresentam reduzida responsividade à glicose, enquanto que ratos alimentados com dietas ricas em ácidos graxos monoinsaturados (óleo de oliva) e poli-insaturados (óleo de soja) demonstram aumento desta resposta (PICINATO et al., 1998). Assim, a exposição aguda aos AGLs de cadeia longa em situações de alta glicose promove a secreção de insulina; no entanto, a exposição crônica às altas concentrações de AGLs ou de glicose pode levar à inibição da secreção de insulina.

Neste contexto, há estudos (CNOP et al., 2001; EITEL et al., 2002; MAEDLER et al., 2001) que afirmam que os ácidos graxos saturados, como o palmitato, são capazes de induzir a apoptose de células beta, enquanto alguns ácidos graxos insaturados teriam efeito antiapoptótico. O mecanismo apoptótico mediado pelos ácidos graxos saturados poderia ocorrer por intermédio da MAP (mitogen-activated protein) quinase, de fosfatases ou pela mobilização de fatores de transcrição, como o STAT 1 (Signal transducer and activator of transcription 1) (EIZIRIK e MANDRUP-POULSEN, 2001).

Os ácidos graxos não iniciam, mas amplificam a secreção de insulina induzida pela glicose. Nas células beta pancreáticas, os AGLs são convertidos a acil-coenzima A (acil-CoA) pela acil-CoA sintase e, em condições basais de glicose $(5,6 \mathrm{mM})$, a cadeia longa de acil-CoA 
(LC-CoA) é transportada para a mitocôndria via carnitina-palmitoil transferase I (CPT-I), onde é beta oxidada. Na presença de concentrações elevadas de glicose (10 mM), este processo é inibido e ocorre aumento na concentração de LC-CoA no citoplasma (UNGER, 1995). Isto se deve à grande formação de malonil-CoA, produzida como resultado do aumento do metabolismo da glicose. A malonil-CoA inibe a CPT-I, permitindo o referido acúmulo de LC-CoA no citoplasma (CHEN et al., 1994) e o desvio do metabolismo de oxidação de ácidos graxos para a oxidação de glicose. As LC-CoAs são efetores essenciais dos mecanismos de transdução de sinal nas células beta, estimulando a $\mathrm{PKC}$, promovendo a acilação de proteínas e modulando o transporte de proteínas (CORKEY et al., 2000), ou alterando a atividade de canais $K_{\text {ATP }}$ (LARSSON et al., 1996) e estimulando $\mathrm{Ca}^{2+}$-ATPases (DEENEY et al., 1992).

Dessa maneira, a participação dos AGLs na secreção de insulina induzida pela glicose se dá não somente através da inibição da oxidação dos AGLs, mas também pelo aumento na esterificação desses ácidos graxos, pela ativação direta da PKC, ou pela síntese lipídica pela própria célula beta (PRENTKI e CORKEY, 1996). Nesse processo, a metabolização da glicose fornece glicerol-3-fosfato necessário à esterificação dos ácidos graxos em outros complexos lipídicos, como o DAG, fosfolipídios e triacilgliceróis, os quais também apresentam importantes funções sinalizadoras e amplificadoras para a secreção de insulina (NOLAN et al., 2006). A glicose é também responsável pela ativação de lipases na célula beta, promovendo a liberação de ácidos graxos com funções sinalizadoras da secreção de insulina (HU et al., 2005). Tais ácidos graxos podem ser exportados pela célula beta, como descrito por Martins et al. (2004), e agir estimulando receptores de membrana autócrina ou paracrinamente. Nesse estudo, foi verificado que a incubação de ilhotas pancreáticas em glicose é capaz de aumentar o conteúdo de ácidos graxos exportados ao meio de incubação, sendo que os ácidos graxos mais potencialmente exportados são o palmítico e o esteárico (MARTINS et al., 2004).

\subsubsection{GPR40}

Estudos atuais (BRISCOE et al., 2003; ITOH et al., 2003; KOTARSKY et al., 2003) demonstram que os ácidos graxos ativam um receptor de membrana plasmática acoplado à proteína G, denominado GPR40 ( $G$ protein coupled receptor). Ele pertence a uma classe de receptores com grande conservação estrutural, sendo altamente expresso em células beta pancreáticas e linhagens celulares secretoras de insulina. O GPR40 é potencialmente ativado 
pelos ácidos graxos mais prevalentes no plasma (BRISCOE et al., 2003; ITOH et al., 2003; KOTARSKY et al., 2003), como o ácido oleico e o ácido palmítico (ver Tabela 1).

Várias regiões do encéfalo humano e monócitos humanos também expressam o GPR40 (BRISCOE et al., 2003). Comprovou-se que a memória espacial e a potenciação de longa duração hipocampal em roedores, e a função cognitiva em humanos são melhoradas através da suplementação com ácido araquidônico e/ou docosaexaenoico, os quais são possíveis ligantes do GPR40 (KOTANI et al., 2006; MCGAHON et al., 1999). Já foi demonstrado que neurônios e astrócitos de macacos apresentam imunorreatividade para o GPR40 em várias regiões encefálicas (MA et al., 2007), porém o papel desse receptor no sistema nervoso central permanece desconhecido. Recentemente, foi demonstrado que as papilas gustativas (CARTONI et al., 2010) e as células K e L intestinais também expressam tal receptor (EDFALK; STENEBERG; EDLUND, 2008; PARKER et al., 2009), onde desempenharia um importante papel sinalizador da ingestão de gordura, contribuindo para a secreção das incretinas GLP-1 (glucagon-like-peptide) e GIP (glucose-dependent insulinotropic polypeptide) na circulação. Dessa maneira, os ácidos graxos exerceriam efeito direto na estimulação da secreção de insulina através da ativação de receptores para ácidos graxos na célula beta pancreática e, indiretamente, ao potencializar a liberação de incretinas.

O papel fisiológico do GPR40 foi estudado através do tratamento de células MIN6 com RNAi (RNA de interferência) específico para GPR40, o que preveniu a estimulação aguda da secreção de insulina induzida pelos ácidos graxos (ITOH et al., 2003), o que é fortemente sugestivo de que esse receptor seja alvo para a ação dos ácidos graxos no pâncreas endócrino.

A ligação do ácido graxo ao GPR40 ativa uma proteína G heterotrimérica, contendo a subunidade $\alpha$ da família $\mathrm{Gq}\left(\mathrm{G} \alpha_{\mathrm{q}}\right)$, a qual é conhecida por estimular a atividade da PLC. Isso culmina na hidrólise do fosfatidilinositol 4,5-bifosfato $\left(\mathrm{PIP}_{2}\right)$ em DAG e $\mathrm{IP}_{3}$, o que, respectivamente, ativa a PKC e mobiliza cálcio do retículo endoplasmático (ver Figura 1), similar ao mecanismo ocorrido na estimulação colinérgica da secreção de insulina (GILON e HENQUIN, 2001). A marcante potencialização da secreção de insulina induzida pelo palmitato fora inibida pela administração de YM-254890, um inibidor da proteína $\mathrm{G} \alpha_{\mathrm{q} / 11}$, indicando que o efeito dos ácidos graxos é mediado, pelo menos em parte, via $\mathrm{G} \alpha_{\mathrm{q} / 11} \mathrm{em}$ ilhotas de camundongos (LATOUR et al., 2007). 
Tabela 1 - Potencial dos ácidos graxos em induzir aumento intracelular de cálcio em células CHO expressando GPR40. Potencial de ativação do GPR40 por diferentes ácidos graxos em diferentes espécies, avaliado em células CHO (Chinese hamster ovary) expressando o GPR40 de cada espécie. $\mathrm{EC}_{50}$ indica a concentração de uma amostra que produz $50 \%$ da resposta máxima e foi calculado a partir de curvas dose-resposta. EPA: ácido eicosapentaenoico, DHA: ácido docosaexaenoico.

\begin{tabular}{|c|c|c|c|}
\hline \multirow[t]{2}{*}{ ÁCIDO GRAXO } & \multicolumn{3}{|c|}{$\mathrm{EC}_{50}(\mu \mathrm{M})$} \\
\hline & Humano & Camundongo & Rato \\
\hline Ácido butírico (C4) & Inativo & Inativo & Inativo \\
\hline Ácido capróico (C6) & Inativo & Inativo & $>300$ \\
\hline Ácido caprílico (C8) & $>\mathbf{3 0 0}$ & Inativo & $>\mathbf{3 0 0}$ \\
\hline Ácido cáprico (C10) & 43 & $>100$ & $>\mathbf{1 0 0}$ \\
\hline Ácido láurico (C12) & 5,7 & 5,6 & 13 \\
\hline Ácido mirístico (C14) & 7,7 & 6,0 & 7,3 \\
\hline Ácido palmítico (C16) & 6,8 & 4,6 & 6,6 \\
\hline Ácido esteárico (C18) & $>300$ & $>\mathbf{3 0 0}$ & $>300$ \\
\hline Ácido oleico (C18:1) & 2,0 & 2,7 & 3,4 \\
\hline Ácido linoleico (C18:2) & 1,8 & 2,9 & 4,1 \\
\hline Ácido $\alpha$-linolênico (C18:3) & 2,0 & 3,6 & 4,0 \\
\hline Ácido araquidônico (C20:4) & 2,4 & 5,4 & 8,0 \\
\hline EPA $(C 20: 5)$ & 2,3 & 4,9 & 9,8 \\
\hline DHA (C22:6) & 1,1 & 16 & 13 \\
\hline
\end{tabular}

FONTE: Modificado de Itoh et al. (2003). 


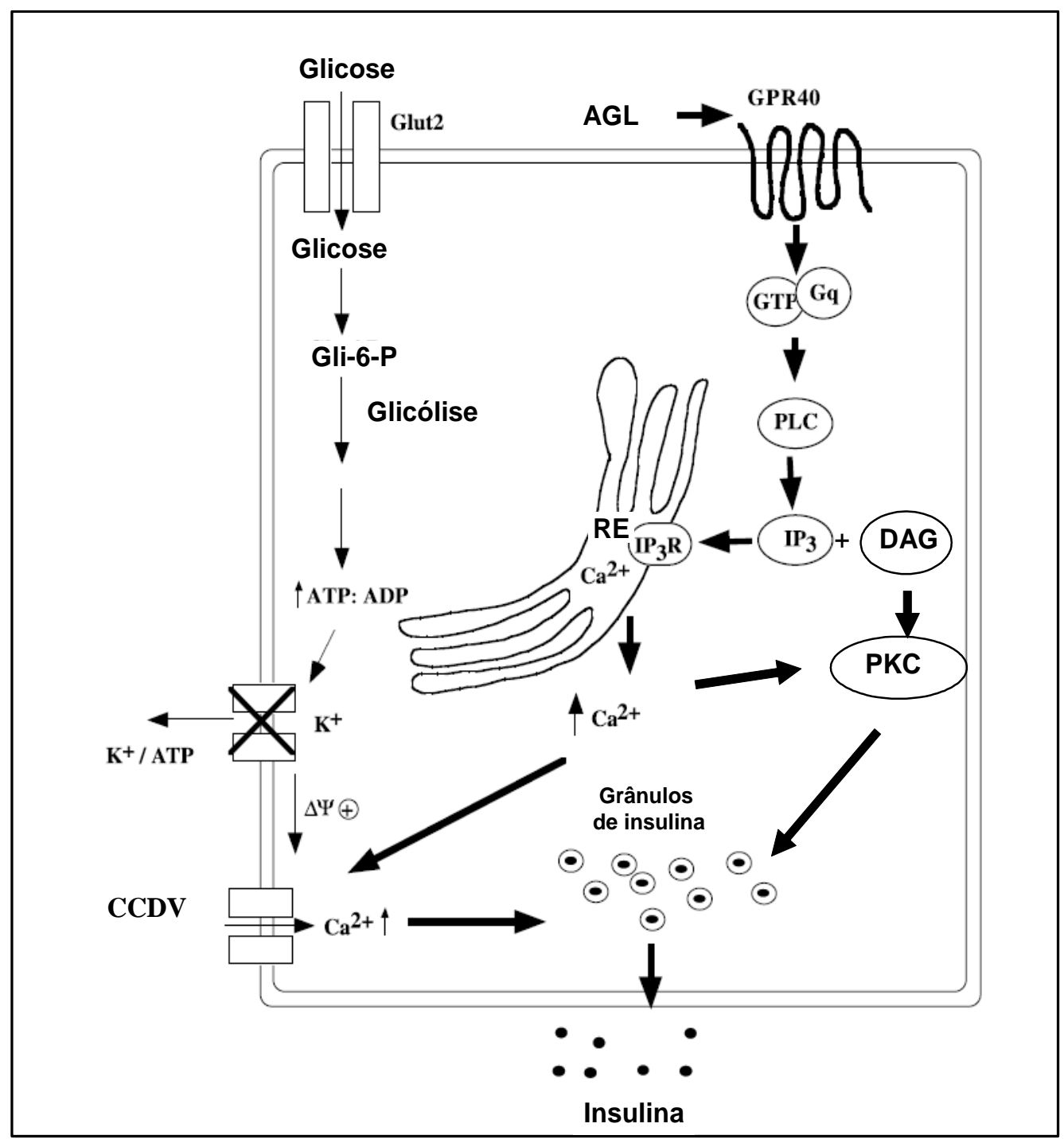

Figura 1 - Mecanismo proposto para a via de sinalização intracelular induzida pelo GPR40 nas células beta. A ativação do receptor pelos ácidos graxos estimula a proteína Gaq e a PLC, levando à liberação de cálcio dos estoques intracelulares. Na presença de cálcio extracelular e elevada glicose, são ativados os CCDV, resultando no influxo de cálcio e secreção de insulina, induzidos pelo ácido graxo. $\mathrm{IP}_{3} \mathrm{R}$ : receptor de $\mathrm{IP}_{3}$, RE: retículo endoplasmático, Gli-6-P: glicose-6-fosfato, CCDV: canal de cálcio dependente de voltagem.

FONTE: Modificado de Shapiro et al. (2005). 
Já foi demonstrado que os ácidos graxos aumentam o conteúdo intracelular de cálcio em células que expressam o GPR40. O bloqueio desse receptor com RNAi específico inibiu o aumento de cálcio intracelular normalmente induzido pela incubação de células beta com o ácido oleico, porém foram mantidas as variações em resposta às altas concentrações de glicose (FUJIWARA; MAEKAWA; YADA, 2005; SCHNELL; SCHAEFER; SCHOFL, 2007). Isso traduz a provável hipótese da ação do ácido graxo ativando o GPR40, o que induziria, secundariamente, o aumento intracelular desse cátion.

Estudos demonstram que a ação dos AGLs aumentando as concentrações intracelulares de cálcio é dependente da ativação da PLC (FUJIWARA; MAEKAWA;

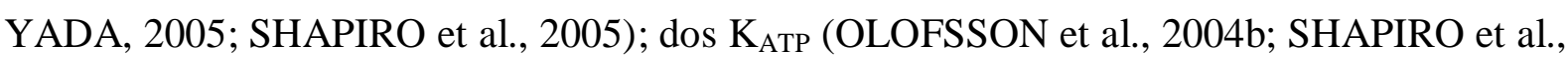
2005); e da ativação de CCDV (FUJIWARA et al., 2005; OLOFSSON et al., 2004b; SHAPIRO et al., 2005). Foi verificado que a ativação do GPR40 pelo ácido palmítico seria também dependente da presença de elevadas concentrações de glicose (SHAPIRO et al., 2005). Tal substrato atuaria como o pré-ativador dos CCDV, ao estabelecer o fechamento dos $\mathrm{K}_{\mathrm{ATP}} \mathrm{e}$, assim, causando a despolarização da membrana plasmática. $\mathrm{O}$ ácido graxo estimularia a atividade do canal de cálcio pré-ativado pela glicose, aumentando a permeabilidade ao cátion e, consequentemente, amplificando a secreção de insulina (ver Figura 1).

A acetilcolina, em um mecanismo análogo, estimula a secreção de insulina através do receptor muscarínico $\mathrm{M} 3$ acoplado a $\mathrm{G} \alpha_{\mathrm{q}}$, provocando a despolarização da membrana através do aumento à permeabilidade ao sódio. Tal despolarização facilita a ativação dos CCDV, que são inicialmente ativados pela glicose e outros secretagogos capazes de despolarizar a membrana da célula beta (GAGERMAN; SEHLIN; TALJEDAL, 1980; GILON; NENQUIN; HENQUIN, 1995; YADA; HAMAKAWA; YAEKURA, 1995). Porém, não são bem conhecidos os mecanismos de transdução que possibilitam a ativação dos CCDV pelos AGLs e, consequentemente, o aumento citossólico de cálcio e a secreção de insulina.

Foi demonstrado também que os canais retificadores de potássio dependentes de voltagem, cuja importância é conhecida no processo de repolarização da membrana durante o estímulo de glicose, têm sua atividade reduzida pela estimulação do GPR40 com o ácido linoleico. Isso produz uma redução da condutância ao potássio, o que atua prolongando a abertura dos CCDV, mantendo elevado o influxo de cálcio (FENG et al., 2006) e assim, amplificando a secreção de insulina. 
A obesidade é associada às elevadas concentrações séricas de ácidos graxos, acúmulo de lipídios nos tecidos, resistência à insulina, hiperinsulinemia e hiperglicemia (MOLLER e KAUFMAN, 2005). No diabetes tipo 2 ocorre falha das células beta em produzir a resposta compensatória ao aumento da demanda de insulina, provocado pela resistência periférica a esse hormônio. Buscando analisar a participação do GPR40 no desenvolvimento da hiperinsulinemia induzida pela obesidade, Steneberg et al. (2005) utilizaram camundongos knock out (KO) para tal receptor. Observou-se que as células beta secretavam menos insulina em resposta aos ácidos graxos e, quando esses camundongos foram submetidos à dieta hiperlipídica, a ausência de expressão do GPR40 protegeu os animais da hiperinsulinemia, da esteatose hepática, da hipertrigliceridemia, da hiperglicemia, do aumento do efluxo hepático de glicose e da intolerância à glicose induzidos pela obesidade (STENEBERG et al., 2005). Todavia, o trabalho de Lan e colaboradores mostrou que tanto camundongos $\mathrm{KO}$ como selvagem para o receptor apresentaram massa corpórea, adiposidade e hiperinsulinemia similares quando submetidos à dieta hiperlipídica, além do que os animais KO não apresentaram melhora no teste de tolerância à glicose e à insulina (LAN et al., 2008). A partir daí, passou a ser profundamente investigada a participação do GPR40 no processo de resistência à insulina e de lipotoxicidade na célula beta.

Também, outros estudos demonstraram que o GPR40 não é responsável pelos efeitos crônicos tóxicos dos ácidos graxos nas ilhotas, visto que o uso do seu agonista após 72 horas de exposição não casou redução da secreção de insulina estimulada pela glicose em ilhotas isoladas (TAN et al., 2008). Além disso, o agonista específico do GPR40 melhorou a tolerância à glicose bem como aumentou a insulina plasmática no teste de tolerância à glicose oral e intravenoso (DOSHI et al., 2009). O estudo de Nagasumi e colaboradores mostrou que camundongos que superexpressam o receptor demonstraram melhora no teste de tolerância oral à glicose e suas ilhotas apresentaram aumento da secreção de insulina em resposta à glicose e ao ácido palmítico. Tais camundongos também se mostraram resistentes à intolerância a glicose induzida por dieta hiperlipídica, entretanto sem ocorrer melhora na sensibilidade à insulina (NAGASUMI et al., 2009).

Latour et al. (2007) demonstraram que camundongos KO para o GPR40 apresentam tolerância à glicose e secreção de insulina em resposta à glicose normais; entretanto a resposta insulínica à administração intravenosa de lipídeos foi reduzida em 50\% (LATOUR et al., 2007). Outros estudos utilizando camundongos KO para o GPR40 mostraram que a secreção de insulina em resposta às elevadas concentrações séricas de ácidos graxos apresentou-se 50\% 
reduzida em relação aos animais controle (LAN et al., 2008). Também, foi verificado que tal redução na secreção de insulina não é oriunda de alterações no metabolismo celular de glicose e de palmitato na ilhota pancreática, nem interfere na sensibilidade à insulina desses animais (ALQUIER et al., 2009). Tais evidências demonstram que, sob condições fisiológicas de estimulação in vivo, a função do GPR40 é relevante, indicando que os eventos mediados através do receptor, bem como os efeitos via metabolização intracelular dos ácidos graxos são somatórios nos mecanismos de ação dos ácidos graxos nas células beta.

Já foram reportados dois polimorfismos relacionados à mutação de um único nucleotídeo na região codificadora do GPR40 humano associados a alterações funcionais. Um deles compreende a substituição do aminoácido arginina por histidina na posição 211 do terceiro loop intracelular, o qual produz aumento da secreção de insulina em homens japoneses (OGAWA et al., 2005). Em outro estudo populacional sobre a mutação pontual associada à perda de função do GPR40 em humanos, responsável pela troca do aminoácido apolar glicina pelo aminoácido polar serina no resíduo 180 do gene do GPR40 (Gli180Ser), foi demonstrada associação importante entre a ocorrência da mutação e a obesidade. Além disso, a secreção de insulina no teste de tolerância oral à glicose é significativamente mais baixa em relação aos indivíduos normais, bem como a insulinemia em resposta a uma sobrecarga lipídica é significativamente inferior nos indivíduos portadores da mutação. Experimentos em células HeLa expressando esse GPR40 mutado revelaram que o aumento intracelular fisiológico de cálcio induzido pela incubação das células na presença do ácido oleico foi significativamente reduzido, demonstrando o comprometimento da função desse receptor mutado (VETTOR et al., 2008).

Em humanos, foi verificada a redução da expressão gênica do GPR40 em ilhotas pancreáticas de indivíduos diabéticos tipo 2 (DEL GUERRA et al., 2010). Dado o proeminente potencial de modulação da secreção de insulina através da atividade do GPR40, inúmeros agonistas farmacológicos do receptor têm sido sintetizados e avaliados como ferramentas no tratamento do diabetes tipo 2, dentre eles, o derivado aminofenil do ácido propiônico (BRISCOE et al., 2006; GARRIDO et al., 2006) e o 4-alcoxi fenil derivado do ácido propiônico (SONG et al., 2007), dentre outros. 


\subsection{Espécies reativas de oxigênio no pâncreas endócrino}

As células podem produzir radicais livres e espécies reativas não-radicalares através de diferentes processos bioquímicos durante o metabolismo celular normal ou alterado. As ilhotas pancreáticas apresentam baixa atividade (GRANKVIST; MARKLUND; TALJEDAL, 1981) e expressão (LENZEN; DRINKGERN; TIEDGE, 1996) das enzimas antioxidantes em relação aos demais tecidos, o que levanta a hipótese da sua susceptibilidade à ação dos radicais livres e espécies reativas não-radicalares.

As espécies reativas de oxigênio (EROs) parecem desempenhar um efeito paradoxal no metabolismo celular, sendo que a exposição crônica a relativamente altas concentrações desses agentes está associada à redução da função das células beta, como também às complicações crônicas do diabetes. Neste contexto, o peróxido de hidrogênio e os radicais superóxido estariam vinculados à hiperglicemia e às complicações vasculares do diabetes, como também à própria origem da doença (CERIELLO e MOTZ, 2004). Porém, existem dados consistentes de que as EROs funcionariam como segundos mensageiros na cascata da via de sinalização ou secreção da insulina (GOLDSTEIN et al., 2005; PI et al., 2007), amplificando a transdução de sinal promovida pela ligação da insulina a seu receptor. Nesse contexto, pequenos aumentos transitórios das concentrações de EROs seriam ocasionados fisiologicamente em resposta a vários fatores de crescimento, citocinas e hormônios, incluindo a insulina.

Um exemplo de produção celular de radicais livres, particularmente, EROs, é aquela catalisada pela nicotinamida adenina dinucleotídeo fosfato oxidase (NADPH oxidase). Apesar de esta ser uma enzima classicamente descrita em células fagocitárias (neutrófilos e macrófagos), vários trabalhos têm demonstrado sua expressão e envolvimento na geração de EROs em outros tipos celulares, tais como células endoteliais e células musculares lisas (GRIENDLING et al., 1994; GRIENDLING; SORESCU; USHIO-FUKAI, 2000), como também nas células beta pancreáticas (OLIVEIRA et al., 2003). A partir da demonstração em ilhotas pancreáticas isoladas (OLIVEIRA et al., 2003) da atividade e da expressão da enzima NADPH oxidase, foi possível verificar que ocorre ativação desta enzima durante o processo de secreção de insulina induzido pela glicose, e que essa ativação é dependente de PKC.

A NADPH oxidase é formada pelos componentes ligados à membrana de vesículas secretórias e grânulos citoplasmáticos, p22 $2^{\mathrm{PHOX}}$ e a glicoproteína gp91 ${ }^{\mathrm{PHOX}}$ (a terminação 
PHOX refere-se à Phagocyte Oxidase), formando uma flavohemeproteína heterodimérica conhecida como citocromo b558 (ROTROSEN et al., 1992). Os outros constituintes da enzima são as subunidades $\mathrm{p} 40^{\mathrm{PHOX}}, \mathrm{p} 47^{\mathrm{PHOX}}$ e p67 ${ }^{\mathrm{PHOX}}$, as quais encontram-se no citoplasma das células fagocitárias não ativadas, formando um complexo; bem como há o complexo citossólico formado pela subunidade Rac mais RhoGDI (NAUSEEF, 2008). A separação desses dois grupos de componentes, citossólicos e de membrana, garante que a oxidase fique inativa.

A NADPH oxidase leucocitária atua como uma cadeia de transporte de elétrons, tendo como aceptor final desses elétrons o oxigênio molecular $\left(\mathrm{O}_{2}\right)$. A oxidase catalisa a produção de ânions superóxido $\left(\mathrm{O}_{2}{ }^{\bullet}\right)$ através da redução da molécula de oxigênio (doação de 1 elétron) e utiliza como doador de elétrons, predominantemente, uma molécula de NADPH (equação 1). Os radicais $\mathrm{O}_{2}{ }^{\bullet-}$ gerados são liberados no interior de fagócitos durante a fagocitose e, devido à sua toxicidade em altas concentrações, promovem a destruição de microrganismos patogênicos. Quando a função da enzima torna-se defeituosa, como visto em pacientes com doença granulomatosa crônica, a habilidade dos fagócitos em eliminar microrganismos é comprometida, ocorrendo infecções persistentes (DINAUER e ORKIN, 1992). Entretanto, a produção de superóxido mediada pela NADPH oxidase em células não-fagocíticas tem função essencial em eventos associados à sinalização celular, tais como o crescimento celular e a mobilidade, a angiogênese, a função imune, a resposta à hipóxia, e a modificação oxidativa de proteínas da matriz extracelular (LAMBETH, 2004).

Os radicais $\mathrm{O}_{2}{ }^{\bullet-}$ são convertidos em peróxido de hidrogênio $\left(\mathrm{H}_{2} \mathrm{O}_{2}\right)$ espontaneamente ou em reação de dismutação catalisada pela superóxido dismutase (SOD) (equação 2). Ao contrário do $\mathrm{O}_{2}{ }^{\bullet-}, \mathrm{o}_{2} \mathrm{O}_{2}$ é uma molécula estável, não carregada e facilmente difusível, que pode ser rapidamente sintetizada e destruída em resposta a estímulos externos (RHEE et al., 2005). Portanto, o $\mathrm{H}_{2} \mathrm{O}_{2}$ apresenta as principais características de um importante e generalizado mensageiro intracelular (GOLDSTEIN; MAHADEV; WU, 2005; RHEE, 2006).

$$
\begin{aligned}
2 \mathrm{O}_{2}+\mathrm{NADPH} & \longrightarrow 2 \mathrm{O}_{2}^{--}+\mathrm{NADP}^{+}+\mathrm{H}^{+} \\
2 \mathrm{O}_{2}{ }^{-}+2 \mathrm{H}^{+} & \longrightarrow \mathrm{H}_{2} \mathrm{O}_{2}+\mathrm{O}_{2}
\end{aligned}
$$


A ativação do complexo NADPH oxidase requer o envolvimento de proteínas $\mathrm{G}$ denominadas Rac. No estado inativo, essas proteínas encontram-se ligadas a guanosina difosfato (GDP); entretanto, quando a célula é estimulada, ocorre a substituição de GDP por guanosina trifosfato (GTP). Tais proteínas G denominam-se Rac1 e Rac 2, que no estado inativo encontram-se no citoplasma formando um complexo dimérico com a Rho-GDI. Durante a ativação, a Rac liga-se ao GTP e migra para a membrana celular, juntamente com os demais componentes citoplasmáticos. Simultaneamente, o citocromo b558 é conduzido à superfície celular através da migração e fusão de vesículas secretórias e grânulos específicos com a membrana plasmática. A Rac 2 é expressa em neutrófilos, já a Rac1 é expressa em monócitos e macrófagos, apresentando expressão ubíqua. A Rac1 provavelmente está associada à ativação do complexo NADPH oxidase em ilhotas pancreáticas e sua função envolveria a ativação do complexo enzimático, através da interação com a p67 ${ }^{\mathrm{PHOX}}$ ou com a subunidade homóloga, a NOXA1 (MOLDOVAN et al., 2006).

A fosforilação é uma etapa essencial na ativação da NADPH oxidase. Foram identificados sítios de fosforilação nos componentes $\mathrm{p} 47^{\text {PHOX }}, \mathrm{p} 67^{\text {PHOX }}, \mathrm{p} 40^{\text {PHOX }}$ e nos componentes de membrana - citocromo b558 (FUCHS et al., 1997). A ativação da enzima é iniciada pela fosforilação em serina e em treonina da subunidade $\mathrm{p} 47^{\mathrm{PHOX}}$, principalmente pela PKC, promovendo a subsequente translocação das subunidades citossólicas para a membrana plasmática (BABIOR, 2002; BEY et al., 2004; FONTAYNE et al., 2002; INOGUCHI et al., 2000).

As principais isoformas de PKC expressas em neutrófilos são a PKC $\alpha$ (alfa), $\beta$ (beta) II, $\delta$ (delta) e $\zeta$ (zeta) (MAJUMDAR et al., 1993). Todas essas isoformas são capazes de fosforilar a $47^{\text {PHOX }}$ quando estimuladas por PMA (NIXON e MCPHAIL, 1999). Ilhotas pancreáticas de rato expressam ao menos seis isoformas de $\mathrm{PKC}[\alpha, \beta, \delta, \varepsilon$ (épsilon), $\zeta$ e $1 / \lambda$ (iota/lambda)] (GANESAN et al., 1992; KNUTSON e HOENIG, 1994), as quais poderiam estar associadas à ativação do complexo NADPH oxidase.

A gp91 ${ }^{\text {PHOX }}$, também chamada NOX2, contem quatro domínios transmembrânicos que são glicosilados em sua região extracelular, além dos grupamentos heme e flavina adenina dinucleotídeo (FAD), que estão envolvidos na atividade de transporte de elétrons da enzima (BABIOR, 2002). Os domínios transmembrânicos contêm os dois grupamentos heme e a região $\mathrm{COOH}$ terminal contem os domínios de ligação ao FAD e ao NADPH. Pelo que é conhecido, os elétrons são transportados do NADPH citoplasmático ao FAD e, após, do 
primeiro heme ao segundo heme e, finalmente, ao oxigênio, gerando o superóxido (BEDARD e KRAUSE, 2007).

A NOX2 constitutivamente associa-se ao p22 ${ }^{\text {PHOX }}$ (o citocromo b558), porém a sua ativação requer a translocação dos fatores citossólicos ao complexo NOX2/ p22 $2^{\mathrm{PHOX}}$. A fosforilação da $\mathrm{p} 47^{\mathrm{PHOX}}$ produz uma alteração conformacional permitindo sua interação com a p22 ${ }^{\text {PHOX }}$ (GROEMPING et al., 2003; SUMIMOTO et al., 1996). A p47 ${ }^{\text {PHOX }}$ organiza a translocação dos demais fatores citossólicos, sendo designada "subunidade organizadora". A localização da $\mathrm{p} 47^{\mathrm{PHOX}}$ na membrana traz a "subunidade ativadora" p67 ${ }^{\mathrm{PHOX}}$ em contato com NOX2 e também a subunidade $\mathrm{p} 40^{\mathrm{PHOX}}$ ao complexo. Finalmente, a GTPase Rac interage com NOX2, seguida de uma subsequente interação com a p67 ${ }^{\text {PHOX }}$ (KOGA et al., 1999; SHEPPARD et al., 2005). Uma vez formado, o complexo é ativo e gera superóxido pela transferência do elétron do NADPH ao oxigênio (ver Figura 2).

Existem proteínas homólogas à gp91 ${ }^{\mathrm{PHOX}}$ ou NOX2, denominadas NOX1, 3, 4 e 5 e DUOX1 e 2. A NOX1 é encontrada principalmente no cólon, a NOX2 em células fagocíticas do sistema imune, a NOX3 no ouvido interno, a NOX4 nos rins e células sanguíneas, a NOX5 em tecidos linfoides e nos testículos, e as subunidades DUOX na tireóide. Entretanto, todas são também expressas em outros tecidos. Ocorrem também proteínas homólogas a outras subunidades da enzima, como NOXO1 ou Proteína Organizadora de NOX, homóloga à p47 $7^{\text {PHOX }}$; e a NOXA1 ou Proteína Ativadora de NOX, homóloga à p67 ${ }^{\text {PHOX }}$. Nem todas as NOX dependem dessas subunidades organizadoras e ativadoras para a ativação do complexo enzimático (BEDARD e KRAUSE, 2007). Foi demonstrado por RT-PCR e posterior sequenciamento dos fragmentos amplificados que, além da NOX2, as ilhotas pancreáticas expressam NOX1, NOX4, p22 ${ }^{\mathrm{PHOX}}, \mathrm{p} 40^{\mathrm{PHOX}}, \mathrm{p} 47^{\mathrm{PHOX}}$, NOXA1 e NOXO1 (UCHIZONO et al., 2006). 


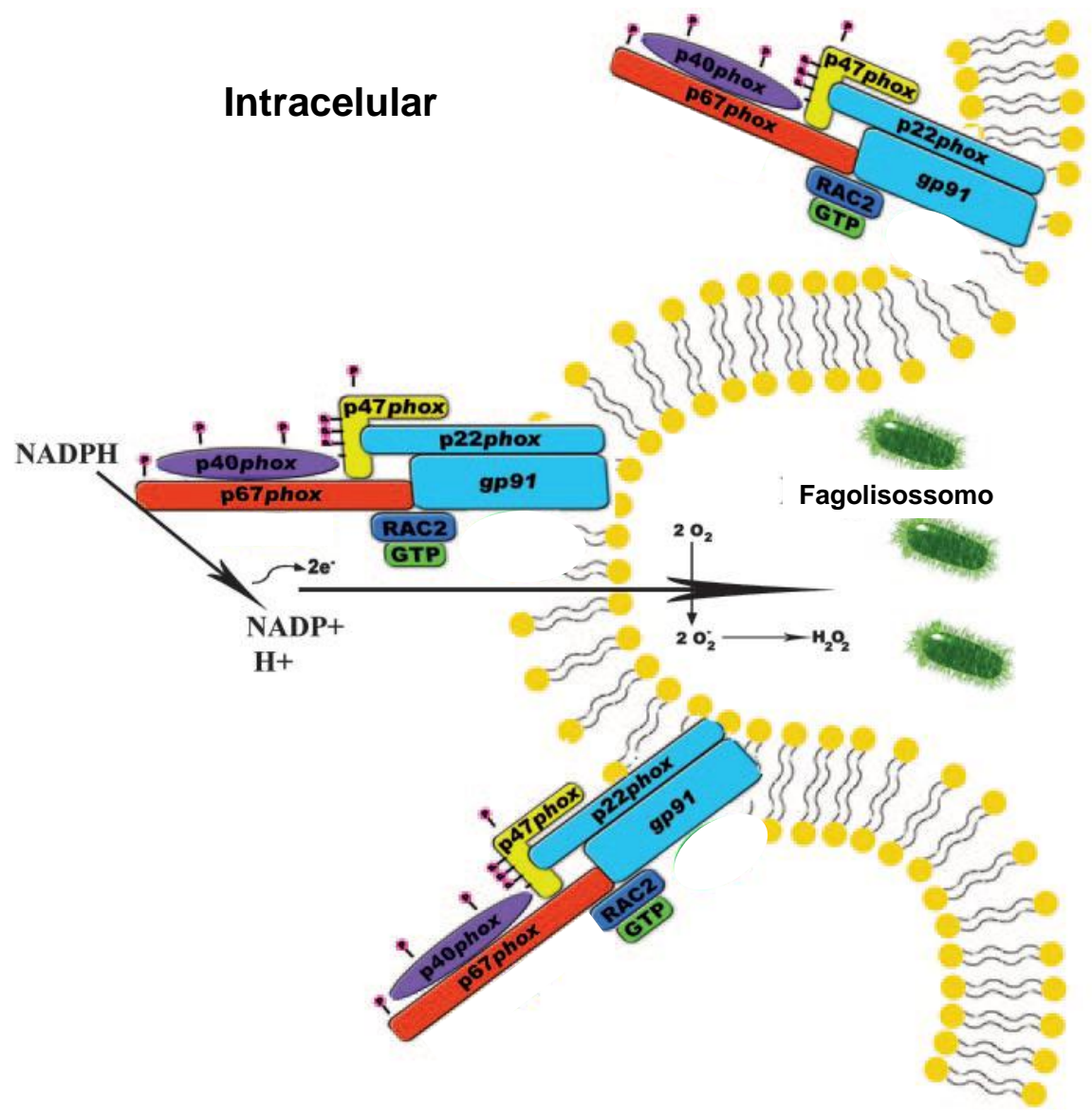

Extracelular

Figura 2 - Esquema representativo do complexo NADPH oxidase ativado em células polimorfonucleares. Translocação dos componentes da NADPH oxidase para a membrana plasmática ou membrana de grânulos intracelulares e a transferência de elétrons através da membrana. Todos os componentes são complexados à membrana, o que inicia a redução do NADPH para NADP e a geração de dois elétrons, que circulam através da membrana via FAD e geram o superóxido.

FONTE: Modificado de Sheppard et al. (2005). 
Quando o complexo NADPH oxidase não está ativo, as subunidades p67 ${ }^{\mathrm{PHOX}}, \mathrm{p} 47^{\mathrm{PHOX}}$ e $\mathrm{p} 40^{\mathrm{PHOX}}$ apresentam-se unidas no citoplasma. Elas possuem diversos domínios para interação com outras proteínas e fosfolipídios de membrana. As subunidades $\mathrm{p} 47^{\mathrm{PHOX}} \mathrm{e}$ $\mathrm{p} 40^{\mathrm{PHOX}}$ possuem na região $\mathrm{NH}_{2}$ terminal um domínio de homologia a phox, ou PX, o qual é um domínio de ligação aos fosfolipídios de membrana e, no caso da $\mathrm{p} 47^{\mathrm{PHOX}}$, especificamente para o fosfatidil-inositol-(3,4) bifosfato (COZIER et al., 2002). A p47 ${ }^{\mathrm{PHOX}}$ também possui o domínio de homologia à $\mathrm{Src} 3$ ou domínio $\mathrm{SH} 3$, o qual interage com a região rica em prolina (PRR) de outras proteínas, havendo a interação de SH3 da p47 ${ }^{\text {PHOX }}$ com a PRR de p22 ${ }^{\text {PHOX }}$. Porém, no estado basal, o SH3 assim como o domínio PX, estão cobertos pela região auto inibitória (AIR), que possui vários sítios de fosforilação responsáveis pela ativação da enzima. A p47 $7^{\text {PHOX }}$ também possui um domínio PRR que interage com o domínio SH3 de p67 ${ }^{\text {PHOX }}$ (BEDARD; LARDY; KRAUSE, 2007). A subunidade homóloga à p47 PHOX, NOXO1, também apresenta o domínio PX, porém com especificidade a outros fosfolípides de membrana. NOXO1 interage com a p22 ${ }^{\text {PHOX }}$ por meio de seu SH3, e apresenta o PRR que permite interação com NOXA1, porém não expressa a AIR (BEDARD e KRAUSE, 2007).

Os dois ativadores homólogos, p67 ${ }^{\mathrm{PHOX}}$ e NOXA1, apresentam domínios similares. Ambos expressam repetições tetricopeptídeos na região $\mathrm{NH}_{2}$ terminal para interação com a Rac e apresentam domínios de ativação, os quais são descritos por permitir a interação entre a p67 $7^{\text {PHOX }}$ e NOX2. As subunidades p67 $7^{\text {PHOX }}$ e NOXA1 têm domínios SH3, que interagem com a $47^{\text {PHOX }}$ e NOXO1, respectivamente (BEDARD e KRAUSE, 2007). A subunidade $440^{\text {PHOX }}$ possui um domínio SH3 de interação com a p47 $7^{\text {PHOX }}$ e um domínio PX de interação com fosfatidil-inositol-trifosfato. Os domínios phox e Bem1 (PB1) da p67 ${ }^{\mathrm{PHOX}}$ interagem com a p40 ${ }^{\text {PHOX }}$ (BEDARD e KRAUSE, 2007).

Quanto ao destino da produção do superóxido produzido pela NADPH oxidase, é sabido que nos fagócitos em estado basal, a maior parte do flavocitocromo b558 é encontrada na membrana de vesículas citoplasmáticas e, ao ocorrer sua ativação, as vesículas são fundidas à membrana e a produção de superóxido ocorre para o exterior da célula (BEDARD; LARDY; KRAUSE, 2007). Porém, tal espécie reativa poderia exercer importante fator sinalizador intracelular ao adentrar a célula através do canal 3 para cloreto, e o peróxido de hidrogênio, oriundo de sua dismutação, poderia também adentrar a célula por meio de aquaporinas (FISHER, 2009).

Já foi demonstrado que altas concentrações de glicose e ácidos graxos, particularmente o ácido palmítico, são capazes de ativar a NADPH oxidase em células endoteliais e 
musculares lisas em cultura, sendo esta ativação dependente de PKC (INOGUCHI et al., 2000). A incubação de uma hora com o ácido palmítico induz aumento da produção de superóxido em células musculares esqueléticas de rato, cuja fonte é oriunda da cadeia de transporte de elétrons mitocondrial, bem como da ativação do complexo NADPH oxidase, visto que existe aumento da fosforilação da subunidade $\mathrm{p} 47^{\mathrm{PHOX}}$ e parcial reversão do conteúdo de superóxido com a administração de DPI, o inibidor farmacológico do complexo enzimático (LAMBERTUCCI et al., 2008).

Foi primeiramente demonstrado em 1963, em músculo cardíaco e esquelético isolados, que os ácidos graxos são oxidados, o que inibe a utilização de glicose por tais tecidos (RANDLE et al., 1963). O aumento da oxidação dos ácidos graxos resulta em um aumento na razão mitocondrial de $\mathrm{NADH} / \mathrm{NAD}^{+}$, o que reduz a atividade da piruvato desidrogenase e, portanto, a oxidação de glicose. Tal aumento na metabolização de ácidos graxos pode também produzir um acréscimo na produção de EROs. É relatado que os ácidos graxos e a glicose provocam a formação de EROs no músculo, em adipócitos, nas células beta e em outros tipos celulares (BROWNLEE, 2005; HABER et al., 2006; TALIOR et al., 2003).

Os principais sítios de produção de superóxido na cadeia de transporte de elétrons são os complexos I e III mitocondriais (ADAM-VIZI e CHINOPOULOS, 2006). O superóxido formado na mitocôndria é rapidamente convertido a peróxido de hidrogênio no compartimento da matriz mitocondrial pela Mn-superóxido dismutase, ou no espaço intermembrana e no citossol pela $\mathrm{Cu} / \mathrm{Zn}$-superóxido dismutase. Já o peróxido de hidrogênio é decomposto pela catalase em água e oxigênio ou reduzido à água e glutationa e, em menor ocorrência, em tiorredoxina, pela glutationa ou tiorredoxina peroxidases, respectivamente (ANDREYEV; KUSHNAREVA; STARKOV, 2005).

Os ácidos graxos modulam a produção mitocondrial de EROs por vários mecanismos, dentre eles, interferindo em vários processos enzimáticos, como por exemplo, inativando a regeneração da glutationa reduzida (GSH) a partir da sua forma oxidada (GSSG), impedindo dessa maneira, a remoção do peróxido de hidrogênio pela glutationa peroxidase. A betaoxidação dos ácidos graxos (acil-CoAs) pode induzir o transporte reverso de elétrons na cadeia mitocondrial aumentando, assim, a produção de superóxido associada ao complexo I. Isso, pois, os elétrons transferidos dos ácidos graxos para a flavoproteína do complexo I adentram a cadeia respiratória por meio da coenzima Q, uma reação mediada pela flavoproteína ubiquinona oxidorredutase. Os ácidos graxos são também conhecidos por interagir com os componentes da cadeia respiratória, inibindo o transporte de elétrons. Além 
disso, ao se incorporarem na membrana interna mitocondrial, eles alteram a sua fluidez, aumentando a probabilidade de vazamento de elétrons e da redução do oxigênio molecular, gerando o superóxido (SCHONFELD e WOJTCZAK, 2008).

Indivíduos com diabetes mellitus tipo 2 apresentam aumento de ácidos graxos circulantes, principalmente dos ácidos graxos saturados, sendo evidente a participação dos mesmos na patogênese da doença. Neste contexto, existem alguns indícios de que os efeitos tóxicos da glicose e dos ácidos graxos sejam, pelo menos em parte, mediados pela ação das EROs. Nesse contexto, foi verificado em modelos de animais diabéticos tipo 2, o aumento da expressão nas ilhotas pancreáticas dos componentes gp91 ${ }^{\text {PHOX }}$ e p22 ${ }^{\text {PHOX }}$ associado ao aumento nos marcadores de estresse oxidativo (8-hidroxi-deoxiguanosina e 4-hidroxi-2nonenal), o que destaca a importância da enzima também no desenvolvimento da doença (NAKAYAMA et al., 2005). O aumento da atividade da NADPH oxidase, induzido pela hipertensão e por altas concentrações de glicose e ácidos graxos, pode estar associado às complicações vasculares e ao rápido desenvolvimento de aterosclerose em pacientes diabéticos.

Sendo assim, novos estudos são necessários para definir os componentes regulatórios e as formas de ativação da NADPH oxidase, bem como seus efeitos fisiopatológicos no pâncreas endócrino e demais tecidos. 


\section{OBJETIVOS}

- Objetivo geral:

Buscamos avaliar as vias de produção de superóxido pelo palmitato em ilhotas pancreáticas e células beta pancreáticas e sua implicação no processo de secreção de insulina.

- Objetivos específicos:

São nossos objetivos, a partir de estímulos de uma hora de incubação em ilhotas pancreáticas de ratas ou linhagem de insulinoma de ratos (INS-1E):

- Avaliar a possível ativação da NADPH oxidase pelo ácido palmítico, bem como a produção de radicais superóxido;

- Avaliar os possíveis mecanismos pelos quais tal ácido graxo module a produção dessa espécie reativa;

- Avaliar a participação da NADPH oxidase no processo de secreção de insulina estimulado pelo ácido palmítico;

- Avaliar a participação do GPR40 na produção de superóxido e secreção de insulina estimulada pelo ácido palmítico. 


\section{MATERIAIS E MÉTODOS}

\subsection{Animais}

Utilizamos ratas Wistar adultas, com 2 a 3 meses e $200 \mathrm{~g} \pm 5 \%$ de peso corporal. Os animais foram mantidos em gaiolas coletivas (cinco por gaiola) em ambiente com temperatura constante de $23 \pm 2{ }^{0} \mathrm{C}$ e sob ciclo de iluminação (claro/escuro) de 12/12 horas (acendimento das luzes artificiais às $7 \mathrm{~h}$ ), tendo livre acesso à água e dieta padrão composta por ração comercial. As ratas foram cedidas pelo Biotério do Instituto de Ciências Biomédicas (ICB) da Universidade de São Paulo. Os procedimentos experimentais empregados no presente trabalho estão de acordo com os Princípios Éticos de Experimentação Animal adotado pelo Colégio Brasileiro de Experimentação Animal (COBEA) e foram aprovados pela Comissão de Ética em Experimentação Animal (CEEA).

\subsection{Isolamento das ilhotas de Langerhans}

A obtenção das ilhotas foi realizada pelo método da digestão do pâncreas exócrino pela colagenase, de acordo com técnicas já estabelecidas (LACY e KOSTIANOVSKY, 1967). Os animais foram decapitados e submetidos à antissepsia da região abdominal com álcool $70 \%$. Foi realizada a laparotomia mediana e a exposição do ducto biliar comum, que foi clampeado na sua extremidade distal e dissecado próximo ao pedículo hepático, por onde foi introduzida uma agulha acoplada à cânula de polietileno e injetados, por via retrógrada, cerca de $20 \mathrm{~mL}$ de solução de colagenase tipo V a 0,7 mg/mL da Sigma (Sigma Chemical Co., St. Louis, MO, EUA) em Hanks. A solução de Hanks contém NaCl 8,00 g/L, $\mathrm{KCl}$ 0,40 g/L, $\mathrm{CaCl}_{2}$ 0,14 g/L, $\mathrm{MgSO}_{4} .7 \mathrm{H}_{2} \mathrm{O}$ 0,20 g/L, $\mathrm{NaH}_{2} \mathrm{PO}_{4}$ 0,48 g/L, $\mathrm{KH}_{2} \mathrm{PO}_{4}$ 0,06 g/L, $\mathrm{NaHCO}_{3}$ 0,35 g/L, $\mathrm{H}_{2} \mathrm{O}$ (qsp): $1,00 \mathrm{~L}$.

A solução flui através dos ductos pancreáticos, provocando o preenchimento do tecido acinar. O pâncreas foi retirado e colocado em placa de Petri para dissecção de gânglios linfáticos, tecido adiposo e vasos sanguíneos, foi fragmentado em pedaços de aproximadamente $1,5 \mathrm{~cm}^{3}$ e depositado em tubo de ensaio de $9,5 \times 5 \mathrm{~cm}$. O tubo foi colocado em banho a $37{ }^{\circ} \mathrm{C}$ durante 25 minutos. A seguir, foi agitado manualmente a $37{ }^{\circ} \mathrm{C}$ por 1 minuto para a digestão da porção exócrina do pâncreas. O conteúdo foi transferido para um 
béquer com solução de Hanks gelado e lavado quatro vezes. Em placa de Petri foi feita a coleta das ilhotas pancreáticas com o emprego de micropipeta e lupa.

\subsection{Isolamento de neutrófilos peritoneais}

As ratas foram decapitadas sem anestesia. Os neutrófilos foram obtidos por lavagem intraperitoneal (ip), usando $40 \mathrm{~mL}$ de PBS (tampão fosfato em solução salina) estéril, 4 horas após injeção ip de $10 \mathrm{~mL}$ de solução de glicogênio de ostra (Sigma) a 1\% em PBS. Esse tratamento induz substancial migração de neutrófilos para a cavidade intraperitoneal com pequena contaminação por monócitos. As células foram centrifugadas (1000 g por 10 minutos) e lavadas duas vezes em PBS.

\subsection{Cultivo celular}

A linhagem clonal de células INS-1E, derivada da linhagem parental INS-1, foi selecionada devido ao seu conteúdo de insulina, responsividade à glicose em concentrações de 5 a 20 mM e adequada proliferação (ASFARI et al., 1992; JANJIC et al., 1999), para a realização da transfecção com o RNAi para GPR40.

As células INS-1E foram cultivadas em atmosfera umidificada contendo $5 \% \mathrm{CO}_{2} \mathrm{em}$ meio RPMI 1640 completo suplementado com 10\% soro fetal bovino (SFB), $1 \mathrm{mM}$ piruvato de sódio, $50 \mu \mathrm{M}$ 2-mercaptoetanol, $4 \mathrm{mM}$ glutamina, $15 \mathrm{mM}$ HEPES, $100 \mathrm{U} / \mathrm{ml}$ penicilina e $100 \mu \mathrm{g} / \mathrm{mL}$ estreptomicina. A manutenção do cultivo se deu através de uma tripsinização por semana, sendo cultivadas $2,5 \times 10^{6}$ células em cada garrafa de $75 \mathrm{~cm}^{2}$ (Techno Plastic Products AG, Trasadingen, Suíça) contendo $20 \mathrm{~mL}$ de meio completo. Para os experimentos de transfecção com RNAi foram cultivadas $9 \times 10^{5}$ ou $4 \times 10^{5}$ células em cada poço das placas para cultivo aderente de 6 poços ou 12 poços, respectivamente (SAarstedt AG \& Co., Nümbrecht, Alemanha), as quais foram utilizadas para transfecção com RNAi após 24 horas de cultivo.

\subsection{Westernblotting}

As amostras com cerca de 350 ilhotas foram pré-incubadas em Krebs-Henseleit contendo $1 \%$ de albumina em 5,6 mM glicose e incubadas em 5,6 ou $10 \mathrm{mM}$ glicose em $1 \%$ de albumina, e sob a adição de $1 \mathrm{mM}$ ácido palmítico previamente diluído em etanol, 
permanecendo em banho a $37^{\circ} \mathrm{C}$. A solução Krebs-Hanseleit contem $115 \mathrm{mM} \mathrm{NaCl}, 5 \mathrm{mM}$ $\mathrm{KCl}, 24 \mathrm{mM} \mathrm{NaHCO} 3,1 \mathrm{mM} \mathrm{CaCl} 2$ e $1 \mathrm{mM} \mathrm{MgCl}_{2}$.

Após a incubação, a solução de incubação foi retirada, as ilhotas foram homogeneizadas em sonicador com tampão de extração [1\% de Triton-X 100, 100 mM de Tris pH 7,4, $100 \mathrm{mM}$ de pirofosfato de sódio, $100 \mathrm{mM}$ de fluoreto de sódio, $10 \mathrm{mM}$ de ácido etilenodiaminotetracético (EDTA), $10 \mathrm{mM}$ de ortovanadato de sódio, $2 \mathrm{mM}$ de fenilmetilsulfonil fluoreto - PMSF e $0,01 \mathrm{mg} / \mathrm{ml}$ de aprotinina], fervidas durante 10 minutos e centrifugadas a $12.000 \mathrm{rpm}$, durante 20 minutos a $4^{\circ} \mathrm{C}$ para a remoção do material insolúvel. Parte do sobrenadante foi utilizada para determinação do conteúdo proteico por espectrofotometria, utilizando-se o reagente para ensaio de proteína "BioRad Protein AssayDye Reagent Concentrate" (Bio-Rad, Melville, NY, EUA) e curva padrão de albumina bovina como referência. O restante do sobrenadante foi diluído em tampão Laemmli (azul de bromofenol 0.1\%, $1 \mathrm{M}$ fosfato de sódio $\mathrm{pH} 7,0$, glicerol 50\% e SDS 10\%) contendo $200 \mathrm{mM}$ de ditiotreitol (DTT), em proporção de 5:1, sendo as amostras mantidas a $-20{ }^{\circ} \mathrm{C}$ até sua utilização. As amostras em tampão Laemmli foram fervidas durante 5 minutos antes de serem aplicadas em gel de poliacrilamida.

O extrato proteico das células INS-1E foi obtido através da adição do tampão de lise RIPA (Upstate, Temecula, CA, EUA) contendo os inibidores de protease, Halt Protease Inhibitor Cocktail kit, da Thermo Scientific (Rockford, IL, EUA). $150 \mu \mathrm{L}$ do tampão RIPA $1 \mathrm{X}$ foi adicionado às células, previamente lavadas em tampão PBS, e homogeneizadas em sonicador. Os lisados celulares foram transferidos para os tubos Eppendorf e então, mantidos sob agitação durante $15 \mathrm{~min}$ a $4{ }^{\circ} \mathrm{C}$. Após, as células foram centrifugadas a $14.000 \mathrm{~g}$ durante 15 min a $4{ }^{\circ} \mathrm{C}$. A fração sobrenadante foi coletada e diluída em tampão Laemmli acrescido de DTT, como acima descrito.

Cerca de 30 a $100 \mu \mathrm{g}$ de proteína total foi submetido à eletroforese em gel bifásico: gel de empilhamento e gel de resolução de 6,5 a $12 \%$ em aparelho para minigel de poliacrilamida (Mini-Protean, Bio-Rad), juntamente com marcador de peso molecular pré-corado disponível comercialmente (Bio-Rad). A transferência das proteínas foi feita eletricamente para uma membrana de nitrocelulose da Millipore (Millipore Corporation, Billerica, Massachusetts, EUA), utilizando aparato para transferência (Bio-Rad) e realizada durante 90 minutos a $120 \mathrm{~V}$ em gelo, banhada em tampão de transferência.

Após a transferência, as membranas foram incubadas em solução bloqueadora ( $5 \%$ de

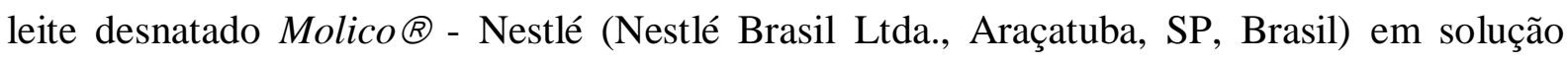


basal composta por $10 \mathrm{mM}$ Tris, $150 \mathrm{mM} \mathrm{NaCl}$ e $0,02 \%$ Tween 20) a $4{ }^{\circ} \mathrm{C}$ overnight ou à temperatura ambiente, durante 2 horas. Após, as membranas foram lavadas 3 vezes durante 10 minutos com solução basal sob agitação. Posteriormente, as membranas foram incubadas com os anticorpos nas concentrações descritas na Tabela 2, overnight, a $4{ }^{0} \mathrm{C}$.

Tabela 2 - Anticorpos utilizados e suas respectivas concentrações nas diferentes metodologias aplicadas.

\begin{tabular}{|c|c|c|c|}
\hline Anticorpo & $\begin{array}{l}\text { Animal de } \\
\text { origem }\end{array}$ & $\begin{array}{l}\text { Immunoblotting } \\
\text { (IB) }\end{array}$ & Imunofluorescência \\
\hline $\begin{array}{c}\text { Policlonal anti-p47 } \\
\text { (Upstate Cell Signalling Solutions) }\end{array}$ & Coelho & $1: 500$ & $1: 50$ \\
\hline $\begin{array}{l}\text { Policlonal anti-gp91 } \\
\text { (Upstate Cell Signalling Solutions) }\end{array}$ & Coelho & $1: 1.000$ & - \\
\hline $\begin{array}{c}\text { Policlonal anti-PKC } \\
\text { (Santa Cruz Biotechnology-Santa Cruz, CA) }\end{array}$ & Coelho & $1: 500$ & $1: 50$ \\
\hline $\begin{array}{c}\text { Policlonal anti-PKC } \alpha \beta \gamma \\
\text { (Upstate Cell Signalling Solutions) }\end{array}$ & Coelho & - & $1: 50$ \\
\hline $\begin{array}{c}\text { Policlonal anti-GPR40 } \\
\text { (Santa Cruz Biotechnology-Santa Cruz, CA) }\end{array}$ & Coelho & $1: 500$ & $1: 50$ \\
\hline $\begin{array}{l}\text { Policlonal anti-p22 } 2^{\text {PHOX }} \\
\text { (Santa Cruz Biotechnology-Santa Cruz, CA) }\end{array}$ & Coelho & $1: 500$ & - \\
\hline $\begin{array}{c}\text { Policlonal anti-SOD1 } \\
\text { (Santa Cruz Biotechnology-Santa Cruz, CA) }\end{array}$ & Coelho & $1: 1.000$ & - \\
\hline $\begin{array}{c}\text { Policlonal anti-phospho-PKC } \\
\text { alpha/beta II (Thr638/641) } \\
\text { (Cell Signaling Technology- Sigma - Saint } \\
\text { Louis, Mi) }\end{array}$ & Coelho & $1: 1.000$ & - \\
\hline $\begin{array}{l}\text { Monoclonal anti- } \alpha \text { Tubulina } \\
\text { ( Zymed - San Francisco, CA) }\end{array}$ & Camundongo & $1: 2.000$ & \\
\hline $\begin{array}{l}\text { Policlonal anti-insulina } \\
\text { (doação Malaisse, WJ - Bélgica) }\end{array}$ & Cobaia & - & $1: 100$ \\
\hline $\begin{array}{c}\text { TRITC anti-cobaia } \\
\text { (Jackson ImmunoResearch Laboratories; } \\
\text { West Grove, PA) }\end{array}$ & Cabra & - & $1: 100$ \\
\hline $\begin{array}{c}\text { FITC anti-coelho } \\
\text { (Jackson ImmunoResearch Laboratories; } \\
\text { West Grove, PA) }\end{array}$ & Cabra & - & $1: 100$ \\
\hline $\begin{array}{l}\text { anti-IgG de coelho ligado à } \\
\text { peroxidase (Amersham Biosciences, USA) }\end{array}$ & Camundongo & $1: 10.000$ & - \\
\hline $\begin{array}{c}\text { anti-IgG de camundongo ligado à } \\
\text { peroxidase (Amersham Biosciences, } \\
\text { USA) }\end{array}$ & Coelho & $1: 10.000$ & - \\
\hline
\end{tabular}


Após incubação, as membranas foram lavadas 3 vezes durante 10 minutos com solução basal sob agitação e incubadas, à temperatura ambiente, com anticorpos secundários anti-IgG ligados a peroxidase (Tabela 2), por 1 hora. Em seguida, as membranas foram lavadas com solução basal sob agitação e reveladas. Para revelação utilizamos os reagentes de quimioluminescência ECL da Millipore. As soluções 1 e 2 foram adicionadas na mesma proporção, recobrindo as membranas e, após 1 minuto de reação, as membranas foram secas em papel filtro, ensacadas e expostas, protegidas da luz, ao filme de raio-X ou analisadas no aparelho ImageQuant, GE Healthcare (GE Healthcare AS, Oslo, Noruega). A intensidade das bandas reativas formadas foi quantificada por densitometria óptica (Scion Image - Release Beta $3 b, N I H, U S A)$.

\subsection{Análise Histológica}

\subsubsection{Fixação e crioproteção do tecido pancreático}

As ratas foram anestesiadas profundamente com quetamina $(20 \mathrm{mg} / 100 \mathrm{~g}$ de peso corporal, ip) e xilazina ( $2 \mathrm{mg} / 100 \mathrm{~g}$ de peso corporal, ip). O tórax foi aberto e aplicado heparina sódica por via intracardíaca para diminuir a formação de trombos. Posteriormente, os animais foram perfundidos transcardiacamente com solução salina tamponada e solução fixadora de paraformaldeído a 1\% (PFA 1\%) em tampão fosfato 0,1 M (PB) em pH 7,4. Foi realizada a retirada do pâncreas, sendo mantido para pós-fixação na mesma solução de PFA $1 \%$ em PB por 1 hora, e então transferido para a solução crioprotetora de sacarose a $30 \%$ em PB por um período de 12 horas. O pâncreas assim obtido foi dissecado e armazenado novamente na solução crioprotetora até o processamento.

\subsubsection{Fixação e crioproteção das ilhotas pancreáticas}

As ilhotas isoladas foram pré-incubadas durante 30 minutos em solução de glicose a $5,6 \mathrm{mM}$ em albumina a $1 \%$ e estimuladas com palmitato a $1 \mathrm{mM}$ e glicose $(5,6$ ou $10 \mathrm{mM})$ em albumina a $1 \%$ e sob a adição de 20 nM PMA durante 1 hora. Posteriormente, foram fixadas em solução de paraformaldeído a 1\% (PFA 1\%) em tampão fosfato 0,1 M (PB) com pH 7,4 durante 30 minutos, sendo posteriormente lavadas 2 vezes com solução crioprotetora de sacarose a $10 \%$ em PB durante 15 minutos. 


\subsubsection{Microtomia}

Para a obtenção de cortes, os pâncreas ou as ilhotas isoladas fixadas foram incluídos em meio de congelamento (Triangle Biomedical Sciences, Durham, NC). As ilhotas isoladas foram incluídas em meio de congelamento dentro de uma forma de canudo plástico. Ambas as preparações foram cortadas (14 ou $12 \mu \mathrm{m}$ de espessura, respectivamente) em criostato, obtendo-se cortes em lâminas gelatinizadas. As lâminas permaneceram em placa aquecida a $37{ }^{\circ} \mathrm{C}$, por 30 minutos. Após este período, foram mantidas a $-20{ }^{\circ} \mathrm{C}$ para posterior reação de imunofluorescência.

\subsubsection{Imunofluorescência}

As lâminas foram, primeiramente, incubadas durante 2 horas em soro normal do animal no qual é produzido o anticorpo secundário, em concentração de 1:20 em Triton X-100 a $0,3 \%$ em PB, buscando reduzir a ocorrência de ligações inespecíficas.

Os cortes foram incubados com anticorpos primários diluídos em Triton X-100 a 0,3\% em PB, nas concentrações indicadas na Tabela 2, por, no mínimo, 12 horas. Após 3 lavagens (10 minutos cada) em PB, os cortes foram incubados por 2 horas com os anticorpos secundários (Jackson Labs, West Grove, PA) (Tabela 2) marcados com os fluoróforos isotiocianato de fluoresceína (FITC) ou tetrametil isotiocianato de rodamina (TRITC) dirigidos contra a IgG dos animais onde os anticorpos primários foram produzidos. A seguir, os cortes foram lavados 3 vezes em PB e cobertos com o meio de montagem para fluorescência Vectashield (Vector Laboratories, Burlingame, CA, USA) e lamínulas.

Os cortes foram analisados em microscópio óptico E1000 Nikon Corporation (Nikon, Tóquio, Japão), observando-se intensidade da imunorreatividade produzida pelos anticorpos. As imagens digitais foram obtidas por meio de uma câmera de vídeo acoplada ao microscópio, e as figuras correspondentes foram montadas com o programa Adobe Photoshop.

\subsection{Análise do conteúdo de ânion superóxido}

\subsubsection{Em ilhotas pancreáticas}

A produção do superóxido $\left(\mathrm{O}_{2}{ }^{\circ}\right)$ foi determinada utilizando o método de fluorescência com diidroetídeo (BINDOKAS et al., 2003). A Hidroetidina (EH) ou Diidroetídeo (DHE) é 
uma sonda redox-sensível, extensamente usada para detectar a produção intracelular de ânion superóxido. Em estudo por HPLC foi demonstrado que a reação entre o superóxido e o DHE resulta na formação de um produto oxidado e este se intercala às bases de DNA, corando o núcleo com uma fluorescência vermelha (ZHAO et al., 2003).

Grupos de 20 ilhotas foram pré-incubadas durante 30 minutos em 5,6 mM glicose e $1 \%$ albumina e incubadas durante 1 hora na presença de $1 \%$ albumina em 5,6 mM ou $10 \mathrm{mM}$ glicose e sob a adição de $1 \mathrm{mM}$ de palmitato a $37{ }^{\circ} \mathrm{C}$ em banho-maria sob agitação. Em seguida, as ilhotas foram retiradas do banho e foi adicionada a hidroetidina numa concentração final de $100 \mu \mathrm{M}$, sendo incubadas por 20 minutos, a temperatura ambiente. Após a incubação, a solução de incubação foi retirada, as ilhotas foram lavadas em KrebsHenseleit e transferidas para lâminas para cultura (chamber slide system).

A produção da fluorescência foi analisada em microscópio confocal (LSM 510 Axiovert 100M - Carl Zeiss; Jena, Alemanha). Para tanto, as ilhotas foram submetidas à excitação com laser de argônio no comprimento de onda 488 nm, sendo a emissão capturada entre os comprimentos de 560 a $615 \mathrm{~nm}$. A obtenção das imagens foi realizada com uma objetiva de 20x, sendo utilizados parâmetros idênticos entre as amostra de uma mesma sequência experimental. Para a quantificação da fluorescência foi feita a projeção das secções e utilizado o programa Image J. (Wayne Rasband, National Institutes of Health, USA). Os dados foram expressos em fluorescência pela área da ilhota pancreática analisada.

\subsubsection{Em linhagem INS-1E}

Foram cultivadas $5 \times 10^{5}$ células para posterior tratamento com RNAi, ou $2 \times 10^{6}$ células em lamínulas redondas de $40 \mathrm{~mm}$ de diâmetro previamente tratadas com L-poli-lisina para análise da produção de superóxido por microscopia confocal. Após o tratamento com RNAi ou 24 horas, as células foram pré-incubadas durante 30 minutos em 11,1 mM glicose e $1 \%$ abumina e incubadas durante 1 hora na presença de $1 \%$ albumina em 2,8 mM ou 16,7 mM glicose e sob a adição de $1 \mathrm{mM}$ de palmitato a $37{ }^{\circ} \mathrm{C}$ em banho-maria sob agitação. Em seguida, adicionou-se hidroetidina numa concentração final de $75 \mu \mathrm{M}$ e incubou-se por 20 minutos, a temperatura ambiente. Após incubação, a solução foi retirada e as células foram lavadas em Krebs-Henseleit. 
Para análise da produção de superóxido, as lamínulas com as células aderidas foram avaliadas em microscópio confocal, como acima descrito. Para a quantificação da fluorescência foi utilizado o programa Image J. e os dados foram expressos em fluorescência pela área de células analisada.

\subsection{Análise da expressão gênica}

\subsubsection{Extração de RNA}

Para a extração dos RNAs totais das ilhotas ou dos neutrófilos peritoneais foi utilizado o reagente Trizol (Invitrogen, EUA), de acordo com as recomendações do fabricante. O tecido foi inicialmente homogeneizado com o reagente Trizol até a completa solubilização. Em seguida, foi incubado durante $5 \mathrm{~min}$ a temperatura ambiente, acrescido de 0,2 $\mathrm{mL}$ de clorofórmio a cada $1 \mathrm{~mL}$ de Trizol, para desproteinização. O sobrenadante foi separado por

centrifugação $\left(12.000 \mathrm{~g}, 15 \mathrm{~min}, 4{ }^{\circ} \mathrm{C}\right)$, e o RNA contido na fase aquosa precipitado com isopropanol, lavado com etanol $75 \%$ e dissolvido em água deionizada previamente tratada com DEPC (dietilpirocarbonato). Os RNAs totais obtidos foram quantificados por espectrofotometria nos comprimentos de onda de 260 e $280 \mathrm{~nm}$. A seguir, as amostras foram submetidas à eletroforese em gel de agarose desnaturante a 1,2\%, para análise da integridade do RNA.

As amostras de RNA (cerca de $15 \mu \mathrm{L}$ ) foram preparadas com tampão de amostra (63 $\mu \mathrm{L}$ de água bidestilada previamente tratada com DEPC, $81 \mu \mathrm{L}$ de formaldeído, $48 \mu \mathrm{L}$ de glicerol com azul de bromofenol, $48 \mu \mathrm{L}$ de MOPS 10X, 0,5 $\mu \mathrm{L}$ de brometo de etídio a 10 $\mathrm{mg} / \mathrm{mL}$ ), aplicadas em gel de agarose e foi iniciada a eletroforese (100 V por 60 minutos). Após a separação por eletroforese, a visualização das bandas foi realizada por exposição do gel à luz ultravioleta.

\subsubsection{RT-PCR (Reação em Cadeia da Polimerase-Transcrição Reversa) em tempo real}

Cada amostra de $3 \mu \mathrm{g}$ de RNA foi submetida à reação de transcrição reversa com primers randômicos. A cada tubo foram adicionados $3 \mu \mathrm{g}$ do RNA total, tampão DNAse 10X e DNAse $(1 \mathrm{U} / \mu \mathrm{L})$. Após incubação de 25 minutos a $25{ }^{\circ} \mathrm{C}$, a DNAse foi inibida com EDTA (25 mM), em seguida foram adicionados primers randômicos (146 ng/ $\mu \mathrm{L})$ e os reagentes tampão RT 5X, DTT (100 mM) e dNTP mix (10 mM). A transcriptase reversa SuperScript III 
foi adicionada e as amostras foram incubadas. A reação foi realizada utilizando termociclador Multicycler PTC-0200 (Mj Researc. Inc, Walhan, MA, USA).

A expressão gênica foi avaliada pela PCR em tempo real utilizando o equipamento ROTOR GENE 6000 (Corbett Research, Mortlake, Austrália) e o SYBR GREEN (Invitrogen, Carlsbad, CA, EUA) para quantificação fluorométrica. A expressão da HPRT (hipoxantina fosforibosiltransferase) foi determinada em paralelo como controle da reação. A quantificação relativa do valor de cada gene alvo foi analisada utilizando o método do $\mathrm{Ct}$ (cycle threshold) comparativo proposto por Livak e Schmittgen (2001). O valor do Ct é o número de ciclos calculado onde o sinal de fluorescência emitido está significativamente acima dos níveis basais. As sequências utilizadas dos pares de primers estão descritas na Tabela 3:

Tabela 3 - Sequências de nucleotídeos dos pares de primers utilizados para análise da expressão gênica de GPR40, p22 ${ }^{\mathrm{PHOX}}, \mathrm{p47}^{\mathrm{PHOX}}$, gp91 ${ }^{\mathrm{PHOX}}$, glicoquinase, pró-insulina e do gene constitutivo, HPRT.

\begin{tabular}{c|l}
\hline Primer & \multicolumn{1}{c}{ Sequência } \\
\hline GPR40 & $\begin{array}{l}\text { sense: 5'-TCC TTT GCC ACC TGG GAC TG -3' } \\
\text { antisense: 5'-CAT TCA CGG GTA TGT TGA TGC C -3' } \\
\text { p22 }\end{array}$ \\
$\begin{array}{c}\text { phox } \\
\text { sense: 5'-GAG }\end{array}$ \\
antisense: 5'-GAA ACT CAA GCA GGA GCC ACT G-3' \\
gp91
\end{tabular}

A expressão do RNA para cada gene foi normalizada pela expressão do gene constitutivo. Os pares de primers para amplificação do gene do GPR40, da p22 ${ }^{\text {PHOX }}$, da 
$\mathrm{p} 47^{\mathrm{PHOX}}$, da gp91 ${ }^{\mathrm{PHOX}}$, da glicoquinase, da pró-insulina e do gene constitutivo HPRT foram desenhados a partir das sequências depositadas no Genbank.

\subsubsection{Cálculo da eficiência dos primers na RT-PCR em tempo real}

A partir do cDNA das amostras controle (incubação a 5,6 mM de glicose) e do cDNA de neutrófilos peritoneais de ratas foram realizadas as curvas de amplificação para cada par de primers, sendo realizadas diluições seriadas das amostras para estabelecer a eficiência de amplificação de cada par de primers (Tabela 3) e posterior análise dos resultados dos produtos amplificados segundo o método proposto por Livak e Schmittgen (LIVAK e SCHMITTGEN, 2001).

A integridade do RNA extraído foi analisada em gel de agarose e realizada a reação de transcrição reversa. A partir dos cDNAs amplificados obtidos, obtivemos a curva do logaritmo da diluição seriada da amostra de cDNA em relação ao Ct (Figura 3A, B, C, D, E, F, G e H). A partir dela, é feito o cálculo da eficiência de amplificação de cada par de primers, a qual deve ter um valor intermediário entre 1,7 e 2,3 (PFAFFL, 2001), necessário à avaliação final da expressão gênica segundo o método proposto por Livak e Schmittgen (2001). Utilizamos também uma amostra controle de neutrófilos peritoneais de ratas para testar o par de primers para a $447^{\mathrm{PHOX}}$ (Figura 3D).

A partir da fórmula $10{ }^{(-1 / \text { CA) }}$ descrita por Pfaffl (2001), sendo CA o coeficiente angular da reta obtida na diluição seriada do cDNA (Figura 3), estabelecemos o grau de eficiência de cada par de primers e, estando dentro do limite previsto, utilizamos o método proposto por Livak e Schmittgen (2001) para análise comparativa da expressão gênica nas diferentes condições analisadas:

- GPR40:

$\mathrm{CA}=-3,3428$

Eficiência $=1,99$

- $\mathrm{p} 47^{\mathrm{PHOX}}$ em ilhotas pancreáticas:

$\mathrm{CA}=-3.3504$

Eficiência = 1,99 
- $\mathrm{p} 47^{\mathrm{PHOX}}$ em neutrófilos isolados:

$\mathrm{CA}=-3.3385$

Eficiência = 1,99

- HPRT:

$\mathrm{CA}=-3,4835$

Eficiência = 1,93

- pró-insulina:

$\mathrm{CA}=-3,6731$

Eficiência $=1,87$

- glicoquinase:

$\mathrm{CA}=-3,3124$

Eficiência $=2,00$

- gp91 ${ }^{\text {PHOX }}$

$\mathrm{CA}=-3,749$

Eficiência $=1,85$

- $\mathrm{p} 22^{\text {PHOX. }}$

$\mathrm{CA}=-3,87$

Eficiência $=1,81$ 

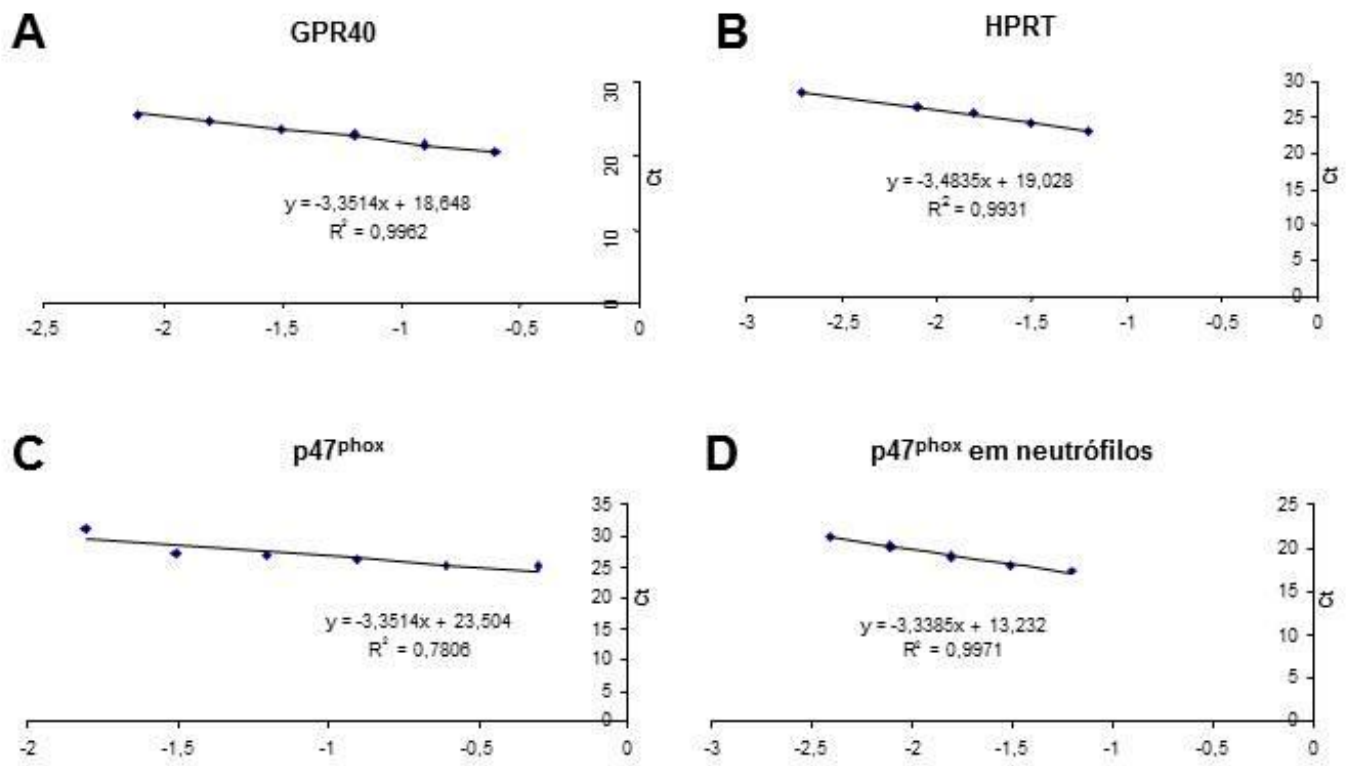

E
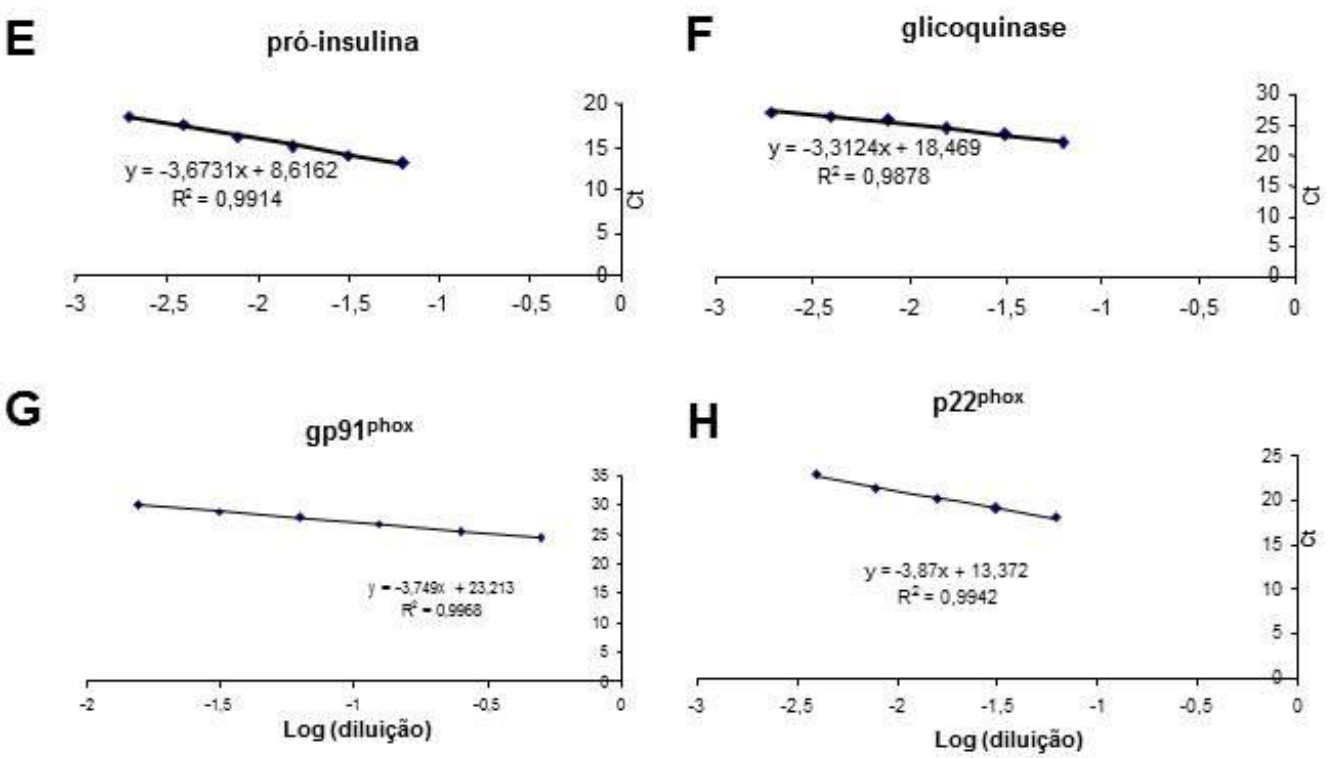

Figura 3 - Curvas obtidas do Ct (cycle threshold) em função do logaritmo da diluição seriada do cDNA da amostra submetida à reação de PCR em tempo real para a avaliação da eficiência dos pares de primers na amplificação do cDNA do GPR40 (A); do HPRT (B); da p47 ${ }^{\mathrm{PHOX}} \mathrm{em}$ ilhotas pancreáticas $(\mathrm{C})$; da $\mathrm{p47}^{\mathrm{PHOX}}$ em neutrófilos peritoneais de ratas (D); da pró-insulina (E); da glicoquinase (F); da gp91 ${ }^{\text {PHOX }}\left(\right.$ G) e da p22 ${ }^{\text {PHOX }}(H)$. 


\subsection{Secreção estática de insulina}

Para a avaliação da secreção estática de insulina, foram utilizados grupos de cinco ilhotas em triplicata para cada condição experimental. As amostras foram pré-incubadas durante 30min em Krebs-Henseleit contendo 1\% de albumina em 5,6 mM glicose e incubadas durante $1 \mathrm{~h}$ em 5,6 ou $10 \mathrm{mM}$ glicose em 1\% de albumina, e sob a adição de $1 \mathrm{mM}$ ácido palmítico previamente diluído em etanol, e/ou $10 \mu \mathrm{M}$ DPI, permanecendo em banho a $37^{\circ} \mathrm{C}$. Após o período de incubação de 1 hora, $300 \mu \mathrm{L}$ do sobrenadante foi removido e estocado a $20{ }^{\circ} \mathrm{C}$ para posterior dosagem de insulina por radioimunoensaio.

Após $24 \mathrm{~h}$ do cultivo da linhagem INS-1E em placa de cultivo aderente ou das $48 \mathrm{~h}$ de transfecção por RNAi, as células foram submetidas a uma pré-incubação em meio RPMI sem glicose durante $2 \mathrm{~h}$ a $37{ }^{\circ} \mathrm{C}$, em atmosfera umidificada contendo $5 \% \mathrm{CO}_{2}$ de acordo com protocolo já estabelecido para a linhagem (MERGLEN et al., 2004). Após, foram lavadas 2 vezes em Krebs-Henseleit sem glicose e pré-incubadas durante $30 \mathrm{~min}$ a $37^{\circ} \mathrm{C}$ em KrebsHenseleit contendo $1 \%$ de albumina sem glicose. Posteriormente, foram lavadas novamente e incubadas durante $1 \mathrm{~h}$ na presença de 2,8 ou $16,7 \mathrm{mM}$ glicose em $1 \%$ de albumina, e sob a adição de $1 \mathrm{mM}$ ácido palmítico, e/ou $20 \mu \mathrm{M}$ GW9508 (agonista do GPR40) e 0,5 $\mu \mathrm{M}$ calphostin C (inibidor de PKC), permanecendo em incubadora a $37^{\circ} \mathrm{C}$. Após a incubação, $300 \mu \mathrm{L}$ do sobrenadante foi retirado e estocado a $-20{ }^{\circ} \mathrm{C}$ para posterior dosagem de insulina por radioimunoensaio.

As ilhotas e a linhagem celular foram posteriormente ressuspensas em $400 \mu \mathrm{L}$ de uma solução de álcool ácido (52 etanol: 17 água: 1 ácido clorídrico) e rapidamente sonicadas, provocando o rompimento das células para dosagem do conteúdo intracelular de insulina. Os dados foram expressos através da normalização da secreção pelo conteúdo de insulina e são demonstrados em relação ao controle (amostra incubada em 5,6 mM glicose para as ilhotas e 2,8 $\mathrm{mM}$ glicose para a linhagem).

\subsubsection{Dosagem de insulina}

A determinação da quantidade de insulina secretada e do conteúdo intracelular de insulina foram determinados por radioimunoensaio. Para tanto, a solução reagente incluiu uma quantidade conhecida de anticorpo, uma quantidade conhecida do hormônio marcado

radioativamente (insulina marcada com iodo $-{ }^{125} \mathrm{I}$, Amershan Biosciences, Inglaterra) e uma 
quantidade desconhecida de hormônio não radioativo (amostra). Como as duas formas do hormônio, radioativos e não radioativos, competem por um mesmo número de sítios de ligação ao anticorpo, quanto mais hormônio não radioativo estiver presente, menos o hormônio radioativo irá se ligar. O complexo insulina-anticorpo marcado formado foi precipitado em polietilenoglicol (PM 6000) e dosado em contador tipo gama (PerkinElmer, Turku, Finlândia). Uma curva padrão foi preparada, na qual a relação ligado/livre para o hormônio radioativo foi plotada como função da concentração do hormônio não radioativo. A relação ligado/livre do hormônio radioativo é maior quanto menor concentração da insulina não radioativa estiver presente. A seguir, a curva padrão foi utilizada para determinar a concentração do hormônio em cada amostra.

\subsection{RNA de interferência para o GPR40}

O silenciamento por RNA é conhecido como um fenômeno natural da resposta imune contra vírus em plantas (BAULCOMBE, 2004). Nesse processo, quando RNAs dupla fita de vários comprimentos são produzidos pela célula ou introduzidos nela, eles são processados pela endoribonuclease Dicer em pequenos RNAs dupla-fita (siRNA ou small interfering $R N A$ ). Esses siRNAs, por sua vez, se associam ao RNAi-inducing silencing complex (RISC) e direcionam a destruição do RNA mensageiro (RNAm) complementar com uma das fitas do siRNA. O RISC cliva o RNAm alvo no meio da região complementar. O pareamento de uma fita do siRNA ao RNAm alvo permite que a RNA polimerase use o RNAm alvo como template e o siRNA como primer, permitindo a produção de novos RNAm dupla fita, os quais poderão ser clivados pela Dicer, contribuindo, dessa maneira, ao pool de novos siRNAs.

Em nosso estudo foi utilizado o siRNA, chamado genericamente como RNA de interferência, para inibir a expressão proteica do GPR40 em linhagem INS-1E através de três sequências de RNA dupla fita de 25 pares de bases (Invitrogen, Carlsbad, CA, EUA) a partir da sequência do GPR40 de rato (GeneID: 266607). O controle negativo (Invitrogen) compreende uma fita dupla de sequências sem qualquer homologia ao transcriptoma dos vertebrados.

As sequências antisense (AS) fornecidas apresentam 25 pares de bases e estão apresentadas na Tabela 4 : 
Tabela 4 - Sequências do RNAi para inibir a expressão do GPR40.

\begin{tabular}{c|c}
\hline $\mathbf{A S 1}$ & 5'-3': AAGAGCAGAAUCGAGAAACUGAGUC \\
& 5'-3': GACUCAGUUUCUCGAUUCUGCUCUU \\
$\mathbf{A S 2}$ & 5'-3': AUUCACGGGUAUGUUGAUGCCCAGG \\
& 5'-3': CCUGGGCAUCAACAUACCCGUGAAU \\
$\mathbf{A S 3}$ & 5'-3': UUCCCAAGUAGCCAGUGACCAGUGG \\
& 5'-3': CCACUGGUCACUGGCUACUUGGGAA \\
\hline
\end{tabular}

\subsubsection{Transfecção da linhagem INS-1E com RNAi}

Foram cultivadas $9 \times 10^{5}$ ou $4 \times 10^{5}$ células em cada poço das placas para cultivo aderente de 6 ou 24 poços (SARSTEDT AG \& Co., Nümbrecht, Alemanha), respectivamente, as quais foram utilizadas para transfecção com RNAi após 24 horas.

As células foram mantidas durante 7 horas a $37{ }^{\circ} \mathrm{C}$ em $1 \mathrm{~mL}$ de meio OPTI-MEM (Invitrogen) com 1,5 $\mu \mathrm{L} / \mathrm{mL}$ Lipofectamina 2000 (Invitrogen) e 11,1 mM de glicose na presença de 100 nM do RNAi para o GPR40 ou do RNAi para o controle negativo, sem qualquer homologia ao transcriptoma dos vertebrados. Após a transfecção, foi retirado o meio de transfecção e adicionado o meio para cultivo celular, o qual foi mantido durante 48 horas a $37{ }^{\circ} \mathrm{C}$.

Para verificar a efetividade da inibição do GPR40 pelo RNAi, após o período de $48 \mathrm{~h}$ de incubação, as células foram lavadas em PBS e homogeneizadas em tampão de lise RIPA para a extração proteica.

\subsection{Análise da integridade de membrana da linhagem INS-1E}

A análise da integridade de membrana foi avaliada por citometria de fluxo. Após as $48 \mathrm{~h}$ de tratamento com RNAi, as células foram tripsinizadas, centrifugadas e ressuspensas em $500 \mu \mathrm{L}$ Krebs-Henseleit. Logo após, foi adicionado $50 \mu \mathrm{L}$ da solução de iodeto de propídeo (IP a $50 \mu \mathrm{g} / \mathrm{mL}$ in PBS) e as células foram analisadas no citômetro de fluxo FACSCalibur (Becton Dickinson, San Juan, California). O IP é um composto fluorescente altamente hidrossolúvel e que, portanto, não ultrapassa membranas intactas, não se incorporando às 
células viáveis. Ele se liga aos ácidos nucléicos, intercalando-se entre as bases nitrogenadas. A fluorescência foi mensurada utilizando o canal FL2 (fluorescência laranja-avermelhada $585 / 42 \mathrm{~nm}$ ) e dez mil eventos foram analisados por amostra. Células fluorescentes pelo IP foram, então, analisadas pelo Cell Quest software (Becton Dickinson) (LIMA et al., 2002).

\subsection{Análise da fragmentação de DNA da linhagem INS-1E}

A análise da fragmentação de DNA foi avaliada por citometria de fluxo. Após as $48 \mathrm{~h}$ de tratamento com RNAi, as células foram tripsinizadas, centrifugadas e lavadas em $500 \mu \mathrm{L}$ Krebs-Henseleit. Foram centrifugadas novamente e ressuspensas em $300 \mu \mathrm{L}$ de solução hipotônica contendo $50 \mu \mathrm{g} / \mathrm{mL}$ IP, $0,1 \%$ citrato de sódio e $0,1 \%$ Triton X-100. Os detergentes presentes na solução permeabilizam as células, que prontamente incorporam o IP nos ácidos nucleicos. Os tubos foram mantidos protegidos da luz e incubados a temperatura ambiente por 2h. A fragmentação de DNA foi analisada por citometria de fluxo após a reação com o IP, de acordo com método já estabelecido (NICOLETTI et al., 1991). A fluorescência foi avaliada e analisada como acima descrito.

\subsection{Análise estatística}

Os resultados foram expressos como média \pm erro padrão da média (EPM) e analisados estatisticamente por análise de variância (ANOVA) de uma via em pós-teste Tukey-Kramer (INStat-Graph Pad Software, Inc., San Diego, CA, USA), adotando como limite mínimo de significância $\mathrm{P}<0,05$. Em comparações entre duas amostras (controle e tratado) em observações pareadas foi utilizado teste $\mathrm{T}$ pareado com limite mínimo de significância $\mathrm{P}<0,05$. 


\section{RESULTADOS E DISCUSSÃO}

Vários mecanismos estão envolvidos no controle da função e sinalização intracelular das células beta pelos AGLs: síntese de moléculas lipídicas sinalizadoras (NOLAN et al., 2006); a modulação da atividade da PKC e sinalização via receptor de insulina (GRACIANO et al., 2009; HABER et al., 2003b; NOGUEIRA et al., 2009); a modulação da atividade de canais de cálcio (OLOFSSON et al., 2004b; WARNOTTE et al., 1994); a acilação de proteínas (CORKEY et al., 2000); e a ativação de receptores de membrana (DOSHI et al., 2009; FUJIWARA; MAEKAWA; YADA, 2005; ITOH et al., 2003; SHAPIRO et al., 2005). O presente estudo investigou as vias de produção de superóxido e a sua participação na secreção de insulina estimulada pelo palmitato.

As fontes de ácidos graxos das células beta são os próprios estoques intracelulares de triglicerídeos e fosfolipídios, além dos AGLs plasmáticos e as lipoproteínas (NOLAN et al., 2006). Os ácidos graxos oriundos dos triglicerídeos plasmáticos acessam as células beta por meio da ação das lipases lipoprotéicas (PAPPAN et al., 2005). Logo, as células beta são provavelmente expostas a maiores concentrações de AGLs em relação ao plasma, entretanto, a concentração de AGLs nas células beta não é conhecida. No plasma, as concentrações de AGLs variam de 0,2 a 1,7 mM, porém, 99\% dos ácidos graxos ou mais estão firmemente ligados à albumina sérica, estando a concentração de ácidos graxos em sua forma livre em torno de 0,01 - $10 \mu \mathrm{M}$ (HIRABARA et al., 2007; SPECTOR; FLETCHER; ASHBROOK, 1971; SPECTOR e HOAK, 1975). No presente trabalho, para alcançar a concentração livre de ácido graxo de 10 - $100 \mu \mathrm{M}$ nas imediações da célula beta, $1 \mathrm{mM}$ palmitato foi adicionado na presença de $1 \%$ albumina livre de ácidos graxos. 


\subsection{Avaliação da distribuição histológica do GPR40 e da p47 ${ }^{\mathrm{PHOX}}$ no pâncreas endócrino}

Através da reação de imunofluorescência em marcação dupla, comprovamos a colocalização do GPR40 nas células produtoras de insulina do pâncreas de ratas (Figura 4), como já descrito em estudos anteriores (BARTOOV-SHIFMAN et al., 2007; BRISCOE et al., 2003; ITOH et al., 2003). Observamos que o padrão de expressão do receptor é muito semelhante ao da insulina, logo, provavelmente o GPR40 não seja expresso nas células alfa, secretoras de glucagon; delta, secretoras de somatostatina; ou PP, secretoras de polipeptídeo pancreático, em ilhotas de ratos.

Porém, em recente trabalho (FLODGREN et al., 2007) foi demonstrado que ilhotas pancreáticas de camundongo expressam o GPR40 nas células alfa, além das células beta. Foi verificado que a linhagem celular de glucagonoma de hamster (In-R1-G9) responde de maneira dose dependente à estimulação com o ácido linoleico, através de elevação dos índices de hidrólise do fosfatidil-inositol, um mecanismo potencialmente ativado via GPR40, e da secreção de glucagon (FLODGREN et al., 2007). Também foi observado que as ilhotas de camundongo secretam glucagon em resposta ao ácido linoleico, um potente ativador do GPR40, o que foi inibido através de oligonucleotídeo antisense contra o GPR40 (FLODGREN et al., 2007).

Observamos também que as ilhotas pancreáticas expressam a subunidade citossólica p $47^{\mathrm{PHOX}}$ da NADPH oxidase nas células beta pancreáticas (Figura 5), como já previamente demonstrado em estudos anteriores (OLIVEIRA et al., 2003; UCHIZONO et al., 2006). Porém, através da reação de imunofluorescência dupla observamos que existem algumas células marcadas negativamente para insulina que apresentam imunorreatividade para a $\mathrm{p} 47^{\mathrm{PHOX}}$ na periferia da ilhota pancreática. Isso é indicativo de que também células endócrinas não beta poderiam expressar a enzima NADPH oxidase, cuja função nesse(s) tipo(s) celular(es) é desconhecida. 

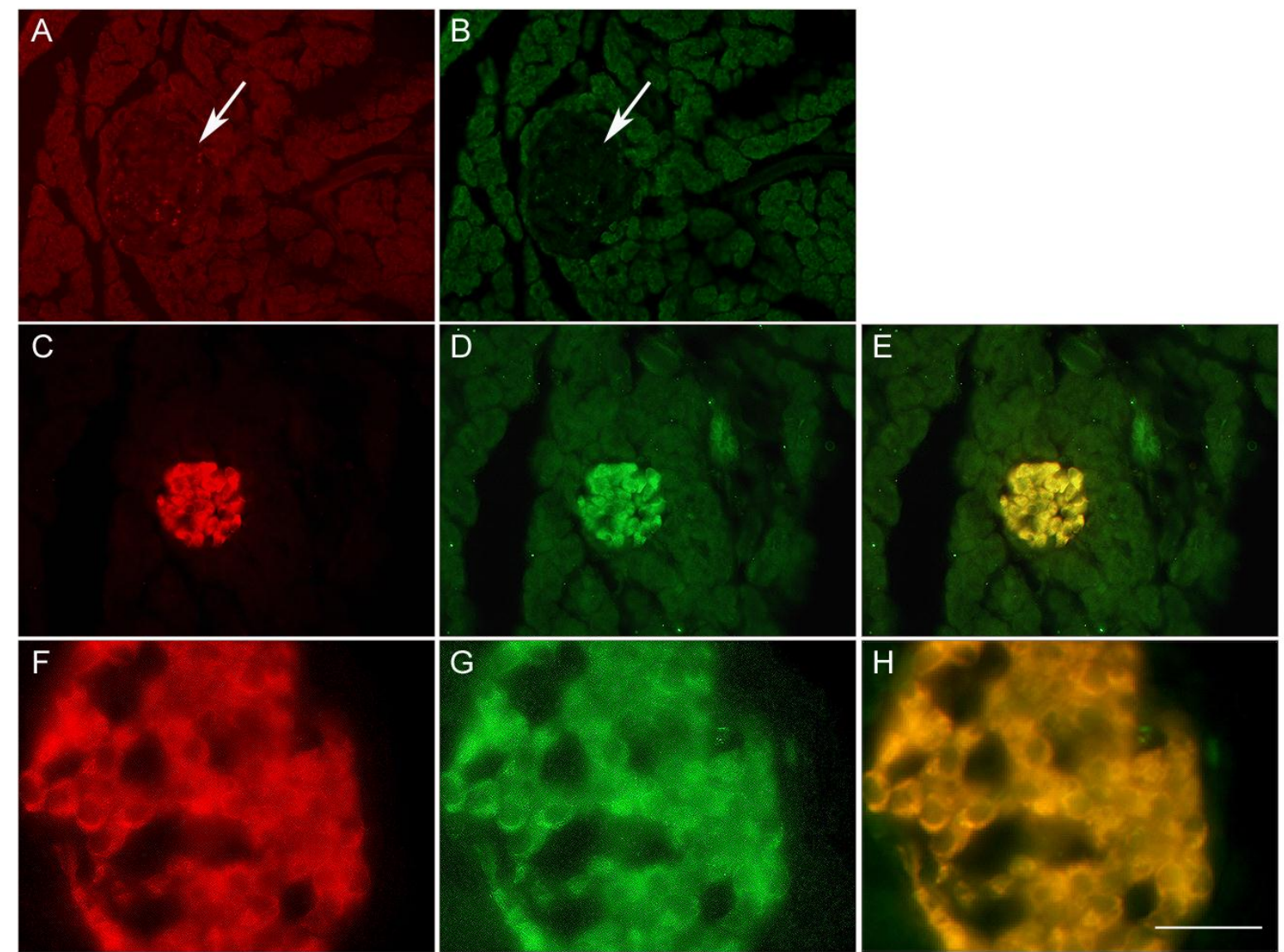

Figura 4 - Imunofluorescência para o GPR40. Cortes histológicos de pâncreas de ratas, de $14 \mu \mathrm{M}$ de espessura, mostrando em A e B. Controle negativo para insulina e GPR40, respectivamente, não havendo a reação com os anticorpos primários (GPR40 e insulina), onde as setas indicam uma ilhota pancreática. C. Ilhota com marcação para insulina. D. Mesma ilhota mostrada em C, com imunorreatividade para o GPR40. E. Sobreposição das imagens C e D. F. Ilhota marcada para insulina. G. Mesma ilhota de F, imunorreativa para o GPR40. H. Sobreposição das imagens F e G. Para A, B, C, D e E, a barra à direita embaixo representa $80 \mu \mathrm{M}$ e para F, G e H, a barra representa $30 \mu \mathrm{M}$. As imagens foram obtidas em microscópio óptico acoplado à câmera Nikon $(n=3$ experimentos independentes). 

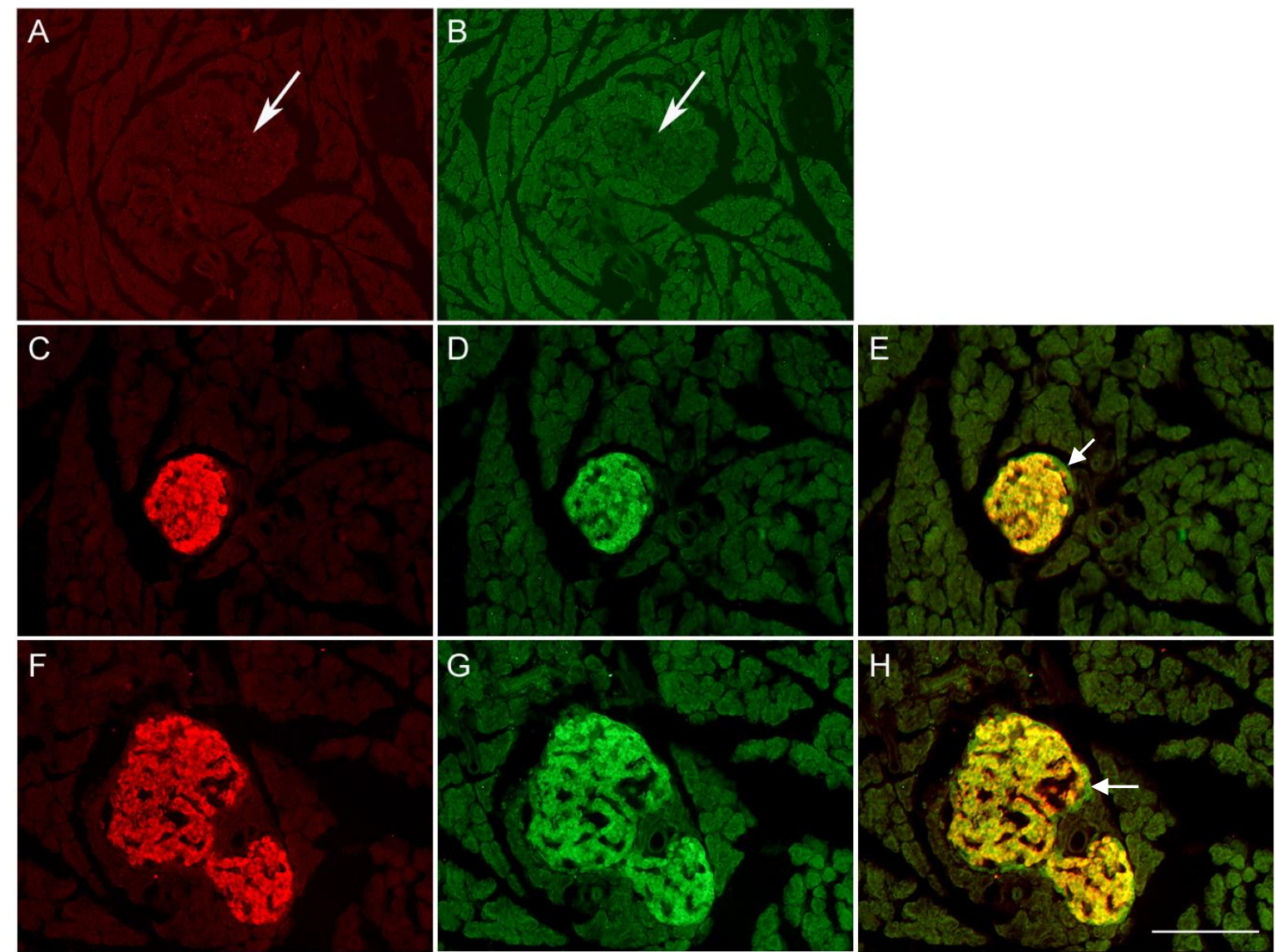

Figura 5 - Imunofluorescência para a p47 ${ }^{\text {PHOx }}$. Cortes histológicos de pâncreas de ratas, de $14 \mu \mathrm{M}$ de espessura, mostrando A e B. Controle negativo para insulina e p47 $7^{\mathrm{PHOX}}$, respectivamente, não havendo a reação com os anticorpos primários (insulina e p47 $7^{\mathrm{PHOX}}$ ), onde as setas indicam uma ilhota pancreática. C. Ilhota com marcação para insulina, D. Mesma ilhota mostrada em C, marcada para $47^{\mathrm{PHOX}}$. E. Sobreposição das imagens C e D, F. Ilhota marcada para insulina, G. Mesma ilhota de F, marcada para a p47 $7^{\mathrm{PHOX}}$ e H. Sobreposição das imagens F e G. As setas em E e H evidenciam a presença de células não-beta imunorreativas para a $\mathrm{p} 47^{\mathrm{PHOX}}$ na ilhota pancreática. A barra à direita embaixo representa $80 \mu \mathrm{M}$. As imagens foram obtidas em microscópio óptico acoplado à câmera Nikon ( $n=3$ experimentos independentes). 


\subsection{Avaliação do conteúdo de ânion superóxido nas ilhotas pancreáticas isoladas}

\subsubsection{Conteúdo de superóxido na presença de palmitato e DPI}

Observamos que a adição de $1 \mathrm{mM}$ palmitato em $1 \%$ de albumina ao meio de incubação em 5,6 mM glicose induziu aumento de 54\% no conteúdo de superóxido em ilhotas incubadas durante 1 hora. Esse aumento é potencialmente inibido pelo DPI (difenilenoiodônio, inibidor da NADP(P)H oxidase), sendo capaz de reduzir o conteúdo de superóxido em 69\% em 5,6 mM glicose na presença do ácido graxo (Figura 6A e ANEXO A). O mesmo foi observado em $10 \mathrm{mM}$ de glicose (Figura 6B e ANEXO A), cuja adição do palmitato induziu aumento de 33\% no conteúdo de superóxido, o qual fora inibido em $61 \%$ pelo DPI. Já havia sido descrito que o aumento da concentração de glicose bem como a adição do ácido palmítico produz, agudamente, elevação no conteúdo de superóxido em ilhotas pancreáticas, como também que tal aumento é oriundo da ativação da NADPH oxidase, visto que fora inibido pelo DPI e por oligonucleotídeo antisense contra a subunidade $\mathrm{p} 47^{\mathrm{PHOX}}$ da enzima (MORGAN et al., 2007; MORGAN et al., 2009).

A produção de superóxido tem sido correlacionada à secreção de insulina estimulada pela glicose, embora haja grande especulação quanto à origem dessa espécie reativa. Foi demonstrado que a glicose e as sulfoniluréias estimulam a produção de EROs em linhagem de células beta (MIN6), através da ativação do complexo NADPH oxidase (TSUBOUCHI et al., 2005), visto que tal efeito fora bloqueado pelo inibidor DPI e pelo inibidor da PKC (calphostin C). Tal dado reforça a importância da NADPH oxidase como fonte catalisadora de EROs na ilhota pancreática estimulada por glicose. Já o trabalho de Leloup e colaboradores destaca o aumento da produção de EROs em ilhotas pancreáticas estimuladas por altas concentrações de glicose, o que estaria diretamente relacionado à secreção de insulina, visto que o uso de antioxidantes inibiu o estímulo secretório (LELOUP et al., 2009).

Observamos que na presença do ácido graxo há um acréscimo no conteúdo de ânions superóxido (Figura 6), demostrando que este pode ser um elemento sinalizador contribuinte à secreção de insulina, mas não determinante. 
A

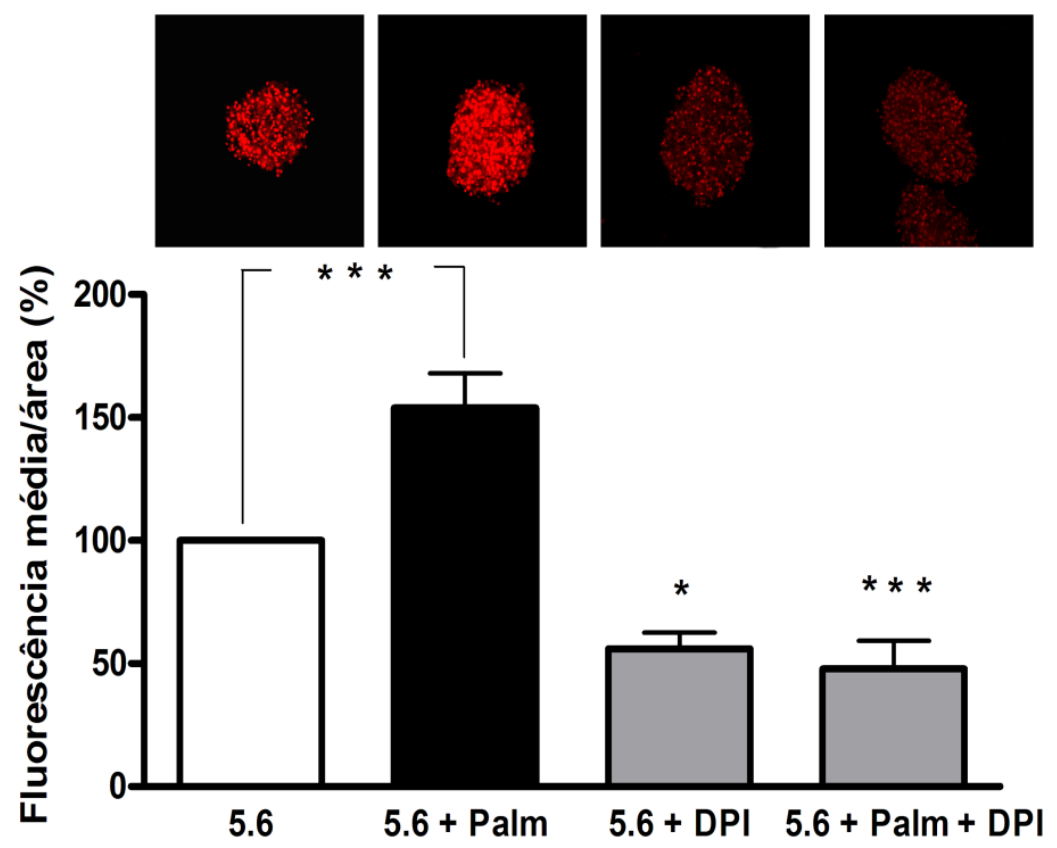

B

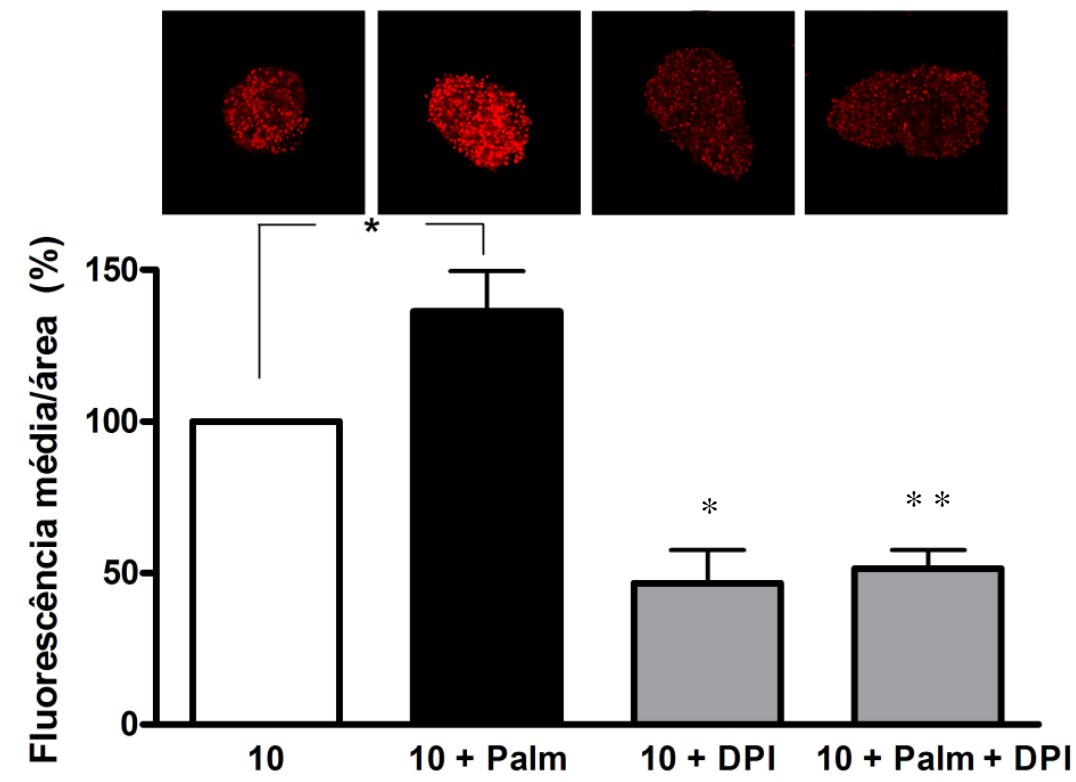

Figura 6 - Efeito do palmitato em 5,6 (A) e 10 (B) mM glicose no conteúdo de superóxido em ilhotas pancreáticas isoladas de ratas. $\mathrm{O}$ conteúdo de superóxido das ilhotas incubadas em 5,6 e $10 \mathrm{mM}$ glicose e sob a adição de $1 \mathrm{mM}$ palmitato (Palm) na presença ou ausência de $10 \mu \mathrm{M}$ DPI durante 1 hora foi determinado pelo método da oxidação da diidroetidina $(n=6)$. A intensidade de fluorescência das ilhotas foi analisada por microscopia confocal. Os resultados são expressos em média \pm EP da fluorescência média por área das ilhotas. As condições na presença de DPI são comparadas, respectivamente, àquelas na ausência do inibidor. $* \mathrm{P}<0,05, * * \mathrm{P}<0,01 \mathrm{e} * * * \mathrm{P}<0,001$. 
Nesse sentido, o palmitato agudamente aumenta a secreção de insulina na presença de altas concentrações de glicose (CARPINELLI et al., 2002; WARNOTTE et al., 1994). Porém, quando as ilhotas pancreáticas são incubadas na presença de concentração basal de glicose, o efeito do palmitato é controverso, tendo sido demonstrado aumento (WREDE et al., 2007), decréscimo (CARPINELLI et al., 2002) ou nenhuma alteração (REMIZOV et al., 2003; WARNOTTE et al., 1994) (Figura 11) na secreção de insulina induzida pela glicose.

Já foi demonstrado que a insulina, por si, estimula a produção de superóxido mediada pela NADPH oxidase em fibroblastos, células musculares lisas, adipócitos e monócitos (CEOLOTTO et al., 2004; FURUKAWA et al., 2004; SAN JOSE et al., 2009; ZHUANG et al., 2004). Porém, observamos que em 5,6 mM glicose sob a adição do ácido graxo existe tal aumento na produção de superóxido, sem estar relacionado ao aumento da função secretória da ilhota pancreática. É importante ressaltar que em 5,6 mM glicose existe uma redução da oxidação de glicose na presença do ácido palmítico, provavelmente devido a uma redução do fluxo de substratos através do ciclo de Krebs. Todavia, ocorre um aumento da oxidação do palmitato e também da sua incorporação em frações lipídicas, principalmente fosfolipídios e triacilgliceróis em ilhotas pancreáticas (CARPINELLI et al., 2002).

Tal aumento de oxidação do ácido graxo é um elemento desencadeador da produção de superóxido, visto que a beta-oxidação é uma importante fonte produtora de EROs. A betaoxidação dos ácidos graxos (acil-CoAs) induz o transporte reverso de elétrons na cadeia mitocondrial, aumentando assim, a produção de superóxido associada ao complexo I mitocondrial. Nesse processo, ocorre a transferência de elétrons oriundos da oxidação dos ácidos graxos, através da acil-CoA desidrogenase para coenzima Q e dela, para a flavoproteína do complexo I da cadeia respiratória (SCHONFELD e WOJTCZAK, 2008). Além disso, ao se incorporarem na membrana interna mitocondrial, os AGLs alteram a sua fluidez, aumentando a probabilidade de vazamento de elétrons e sua reação com o oxigênio molecular (SCHONFELD e WOJTCZAK, 2008).

O palmitato já foi descrito como indutor da produção de EROS em células endoteliais, em células musculares aórticas, (INOGUCHI et al., 2000), em células musculares esqueléticas (LAMBERTUCCI et al., 2008) e em adipócitos (MULLER et al., 2008) em um processo também dependente da NADPH oxidase. Em trabalho desenvolvido por Lambertucci e colaboradores (2008) foi verificado que a produção de superóxido por células musculares esqueléticas induzida pelo palmitato após 1 hora de incubação é reduzida pela adição de etomoxir (inibidor da CPT-I) e de bromo-palmitato (análogo não metabolizável do palmitato), 
demonstrando a importância da oxidação dos ácidos graxos como fonte geradora de superóxido (LAMBERTUCCI et al., 2008).

Em nosso estudo, ao utilizarmos o inibidor irreversível da CPT-I, o etomoxir, observamos que o conteúdo de superóxido é reduzido na presença de 5,6 $\mathrm{mM}$ glicose e do ácido palmítico (Figura 7A), e não se apresenta alterado em $10 \mathrm{mM}$ glicose com o ácido graxo (Figura 7B). Tal resultado evidencia a importância da beta-oxidação como fonte geradora de radicais superóxido em situações de concentrações basais de glicose, quando é poupada a oxidação da glicose (CARPINELLI et al., 2002; HELLEMANS et al., 2007).

Já em concentrações elevadas de glicose, tal participação não é evidente, visto que pouco ácido graxo é oxidado, sendo preponderante a oxidação da glicose (CARPINELLI et al., 2002; HELLEMANS et al., 2007). No estudo de Lehtihet e colaboradores foi demonstrado que em condição de baixa concentração de glicose $(3 \mathrm{mM}), 50 \mu \mathrm{M}$ de etomoxir é capaz de reduzir em $70 \%$ a oxidação do palmitato em ilhotas pancreáticas de rato (LEHTIHET et al., 2003). Tendo sido utilizada a mesma concentração do inibidor em nossos experimentos, evidenciamos que o efetivo bloqueio à oxidação do ácido graxo é capaz de inibir a produção de radicais superóxido.

Ao compararmos o conteúdo de superóxido em ilhotas incubadas com palmitato durante 1 hora em 5,6 e 10 mM glicose (Figura 8), observamos que a produção desse radical livre é superior em 5,6 mM glicose, o que pode evidenciar, dentre outros fatores, a participação da beta-oxidação como fonte de radicais superóxido em concentrações de glicose não estimulatórias da secreção de insulina. Tal evidência também pode advir da ativação das defesas antioxidantes em alta glicose, dismutando o superóxido em peróxido de hidrogênio através da superóxido dismutase (SOD), mantendo o balanço redox celular e prevenindo os efeitos tóxicos das espécies radicalares. Já foi verificado que a atividade da $\mathrm{Cu} / \mathrm{Zn}$-SOD ou SOD-1, enzima encontrada no citossol, aumenta com a concentração de glicose e que tal potencialização está fortemente correlacionada ao aumento da secreção de insulina (OLIVEIRA; CURI; CARPINELLI, 1999). Portanto, a ativação da Cu/Zn-SOD por concentrações estimulatórias de glicose pode prevenir maiores acréscimos na concentração de superóxido celular, o que justificaria a redução no conteúdo de superóxido na presença do palmitato em alta glicose em relação ao palmitato em baixa glicose. 
A
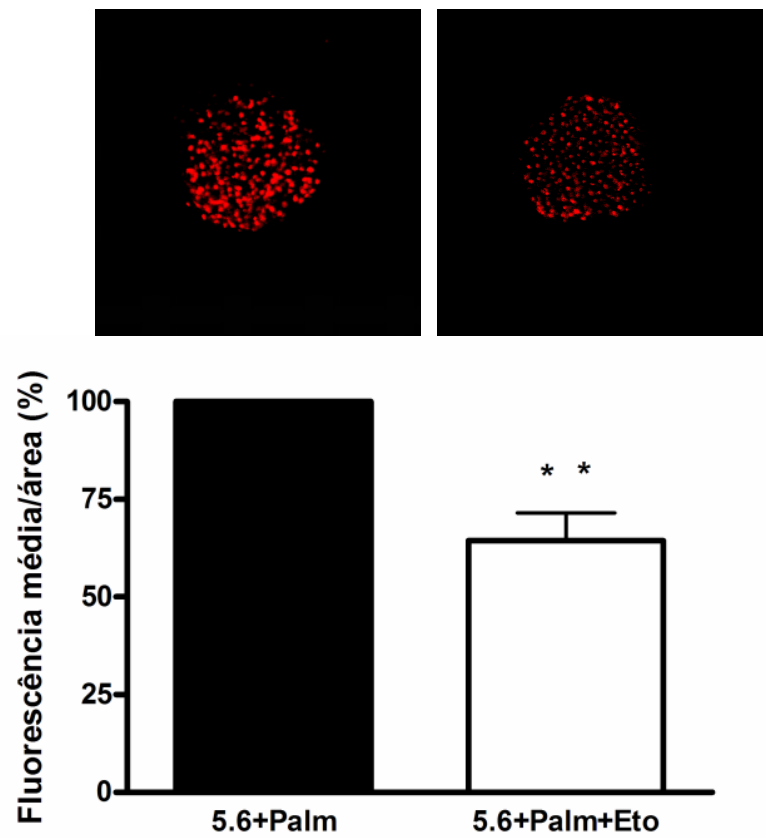

B
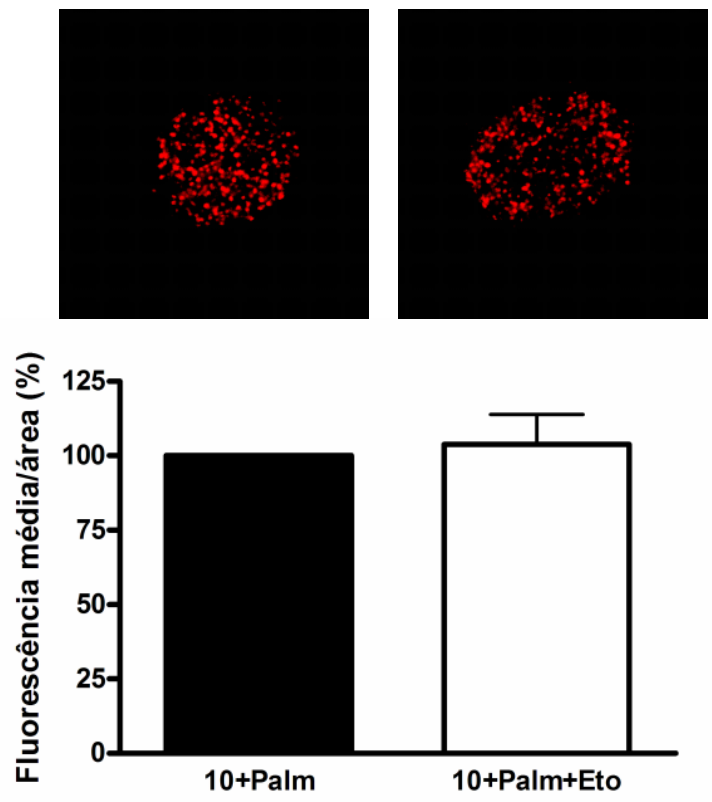

Figura 7 - Efeito de $50 \mu M$ etomoxir (Eto) na produção de superóxido induzida por palmitato em 5,6 e 10 mM glicose. O conteúdo de superóxido das ilhotas pré-incubadas durante 1 hora em 5,6 mM glicose, na presença ou ausência de $50 \mu \mathrm{M}$ etomoxir e incubadas em 5,6 (A) ou 10 (B) mM glicose na presença de $1 \mathrm{mM}$ palmitato e sob a adição de $50 \mu \mathrm{M}$ etomoxir durante 1 hora foi determinado pelo método da oxidação da diidroetidina ( $n=5$ e 8). A intensidade de fluorescência das ilhotas foi analisada por microscopia confocal. Os resultados são expressos em média \pm EP da fluorescência média por área das ilhotas. $* * \mathrm{P}<0,01$. 

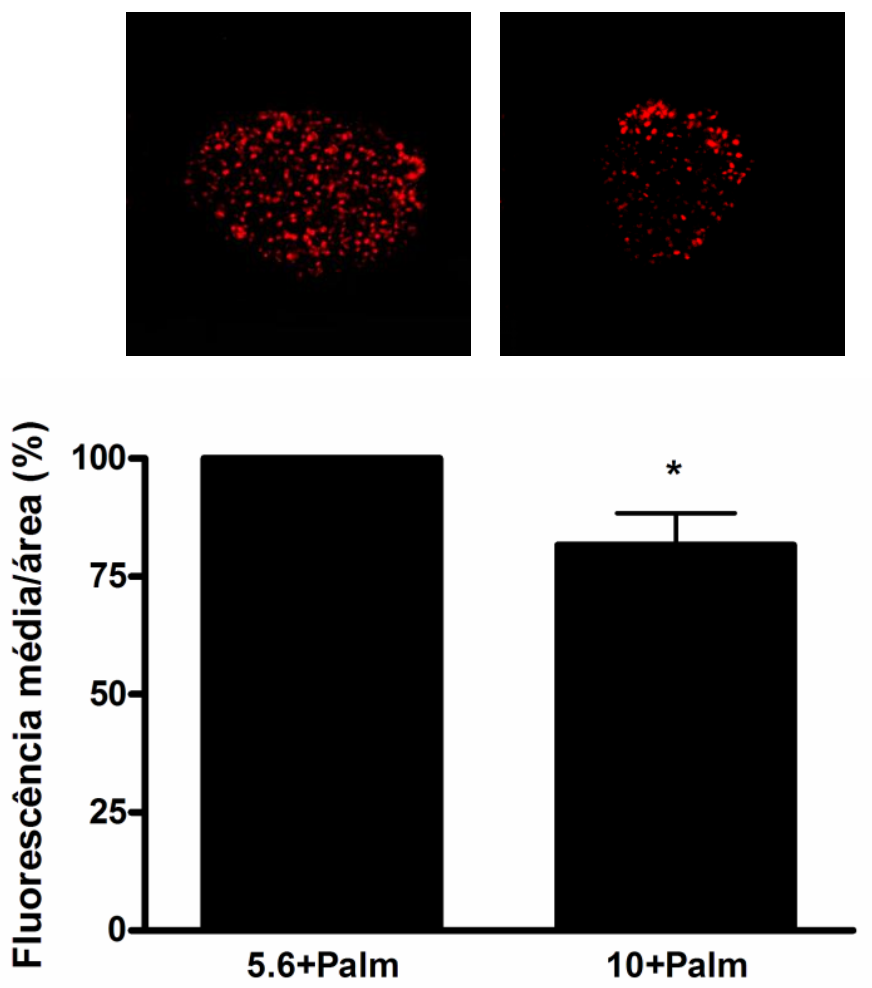

Figura 8 - Efeito do palmitato em 5,6 e $10 \mathrm{mM}$ glicose no conteúdo de superóxido em ilhotas pancreáticas isoladas de ratas. $\mathrm{O}$ conteúdo de superóxido das ilhotas incubadas em 5,6 ou $10 \mathrm{mM}$ glicose e sob a adição de $1 \mathrm{mM}$ palmitato (Palm) durante 1 hora foi determinado pelo método da oxidação da diidroetidina $(n=10)$. A intensidade de fluorescência das ilhotas foi analisada por microscopia confocal. Os resultados são expressos em média \pm EP da fluorescência média por área das ilhotas. $* \mathrm{P}<0,05$. 
Pi et al. (2007) demonstraram que a glicose aumenta o conteúdo intracelular de peróxido de hidrogênio não oriundo da função mitocondrial, e que a secreção de insulina pode ser estimulada pela adição do peróxido de hidrogênio ou dietil maleato, o qual aumenta o conteúdo intracelular dessa espécie reativa (PI et al., 2007). Eles também verificaram que a administração dos antioxidantes catalase e $\mathrm{N}$-acetil-cisteína reduziu o acúmulo de peróxido de hidrogênio e a secreção de insulina induzidos pela glicose. Estudo realizado em ilhotas pancreáticas de ratos evidenciou que essa mesma espécie reativa produz uma rápida e transiente elevação do conteúdo intracelular de cálcio acompanhado de aumento na secreção de insulina em concentrações de glicose não-estimulatórias da secreção insulínica (JANJIC et al., 1999; MAECHLER; JORNOT; WOLLHEIM, 1999).

Já a exposição aguda de ilhotas isoladas à xantina oxidase/hipoxantina, conhecido sistema gerador de radicais superóxido, produziu elevação aguda da secreção de insulina (EBELT et al., 2000). Tais evidências colaboram para a caracterização do superóxido como participante da amplificação da resposta insulínica, visto que existe uma dependência da presença do cálcio extracelular para as EROs estimularem a secreção de insulina (PI et al., 2007).

Outro exemplo da função sinalizadora celular das EROs foi demonstrado em adipócitos diferenciados (3T3-L1), onde a produção de peróxido de hidrogênio dependente da ativação da NADPH oxidase pelo estímulo insulínico está associada à potencialização da ação da insulina através da inibição da PTP-1B (GOLDSTEIN; MAHADEV; WU, 2005; GOLDSTEIN et al., 2005). A PTP-1B é uma fosfatase que regula negativamente a ação da insulina através da inibição da fosforilação do IR (receptor de insulina) e dos IRSs (substratos do receptor de insulina). O domínio catalítico cisteína da fosfatase, ao ser oxidado pelo peróxido de hidrogênio, bloqueia a atividade enzimática da PTP-1B e, portanto, é potencializada a ação da insulina (MAHADEV et al., 2001a; MAHADEV et al., 2001b).

\subsubsection{Conteúdo de superóxido na presença de palmitato e calphostin C}

Buscando avaliar a participação das PKCs na produção de superóxido induzida pelo palmitato, utilizamos o calphostin $\mathrm{C}$, um inibidor da $\mathrm{PKC}$ que impede a ligação do DAG à PKC. Através desse mecanismo, ele inibe todas as isoformas convencionais (dependentes da ativação por DAG e cálcio) e as isoformas novas (dependentes da ativação via DAG) de PKC. 
Observamos que $1 \mu \mathrm{M}$ calphostin C inibiu em cerca de $40 \%$ a produção de superóxido em 5,6 e $10 \mathrm{mM}$ de glicose na presença do ácido palmítico (Figura 9). Isso reforça a participação dessa via na produção de superóxido. Além disso, a incubação de calphostin $\mathrm{C}$ a $1 \mu \mathrm{M}$ causou marcante redução do efeito agudo do palmitato na secreção de insulina de ilhotas pancreáticas na presença de 16,7 mM glicose (THAMS e CAPITO, 2001), destacando a importância das PKCs novas e convencionais na potencialização da secreção de insulina estimulada por ácidos graxos.

Estudos demonstram que a inibição da PKC pelo GF109203X (bisindoilmaleimide), ou por calphostin $\mathrm{C}$, reduz a produção de EROs em ilhotas pancreáticas de rato estimuladas por glicose (MORGAN et al., 2007; OLIVEIRA et al., 2003) e em linhagem de células beta (MIN6) estimulada por sulfoniluréias (SAWADA et al., 2008).

Vários estudos têm evidenciado a importância de PKCs convencionais e novas ( $\alpha$ e $\delta$, respectivamente) na ativação da $\mathrm{p} 47^{\mathrm{PHOX}}$ em linhagem celular de fibroblastos humanos e em macrófagos (HIGAI et al., 2008; IACCIO et al., 2007), o que também nos sugere o seu provável envolvimento também no tecido pancreático endócrino, haja visto os resultados no conteúdo de superóxido (Figura 9), como também que os ácidos graxos são conhecidos ativadores dessas isoformas de PKC (HABER et al., 2003b).

Nesse contexto, a geração de cálcio e DAG, como decorrentes da estimulação pelo ácido graxo em ilhotas pancreáticas, leva ao ancoramento da PKC à membrana, à liberação do pseudosubstrato da cavidade de ligação do substrato, permitindo que a enzima fosforile outras proteínas; estando, dessa maneira, em sua forma ativa (NEWTON, 2003). A serina treonina quinase PKC é o principal regulador da NADPH oxidase em leucócitos, onde induz a ativação dependente de fosforilação dos componentes citossólicos da oxidase. Portanto, a ativação das PKCs pelo palmitato pode ocorrer através da ativação dos CCDV ou da formação de LCCoAs que, ao conjugarem-se ao glicerol-fosfato, geram DAG, como ocorre em alta glicose; ou através da ativação do receptor GPR40, seja em alta ou baixa glicose, que através da ativação de uma proteína $\mathrm{G} \alpha_{\mathrm{q}}$ culmina na ativação das PKCs. Ao inibirmos a PKC, estaríamos retirando um importante mecanismo regulador da NADPH oxidase, reduzindo, dessa maneira, a produção de superóxido por ela induzida. 
A
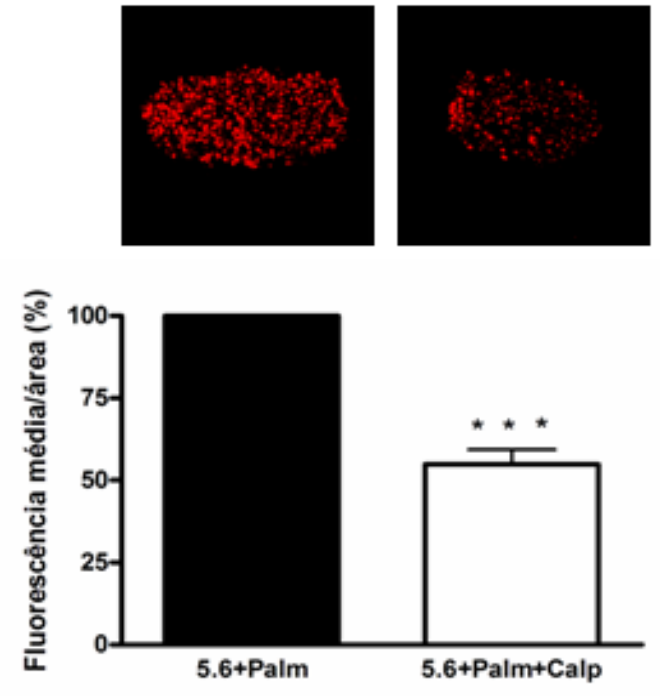

B
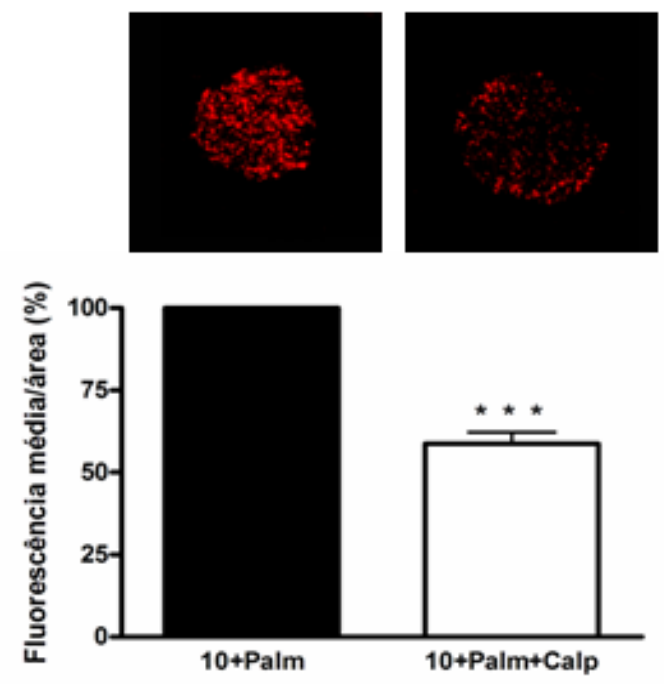

Figura 9 - Efeito do inibidor da PKC no conteúdo de superóxido induzido pelo palmitato em 5,6 e $10 \mathrm{mM}$ glicose. O conteúdo de superóxido das ilhotas pré-incubadas durante 30 minutos em 5,6 mM glicose, na presença ou ausência de $1 \mu \mathrm{M}$ calphostin C (Calp) e incubadas em 5,6 (A) ou 10 (B) $\mathrm{mM}$ glicose na presença de $1 \mathrm{mM}$ palmitato e sob a adição de $1 \mu \mathrm{M}$ calphostin $\mathrm{C}$ (Calp) durante 1 hora foi determinado pelo método da oxidação da diidroetidina $(n=8)$. A intensidade de fluorescência das ilhotas foi analisada por microscopia confocal. Os resultados são expressos em média \pm EP da fluorescência média por área das ilhotas. $* * * \mathrm{P}<0,001$. 


\subsubsection{Conteúdo de superóxido na presença de SOD}

Com o intuito de confirmar a mensuração de superóxido pelos experimentos acima descritos, realizamos a incubação das ilhotas na presença de $100 \mathrm{U} / \mathrm{mL}$ superóxido-dismutase conjugada ao polietilenoglicol (PEG-SOD), cuja conjugação confere facilitação à entrada da enzima no interior de célula e diminui a sua sensibilidade à proteólise (BECKMAN et al., 1988b, a). Dessa maneira, torna-se capaz de catalisar a conversão intracelular do superóxido em peróxido de hidrogênio.

A Figura 10 apresenta a redução em cerca de $60 \%$ no conteúdo de superóxido em ilhotas incubadas em 5,6 e $10 \mathrm{mM}$ glicose na presença do palmitato, confirmando a especificidade do método da oxidação da diidroetidina para detecção do conteúdo intracelular de superóxido em nossos modelos de incubação. 
A
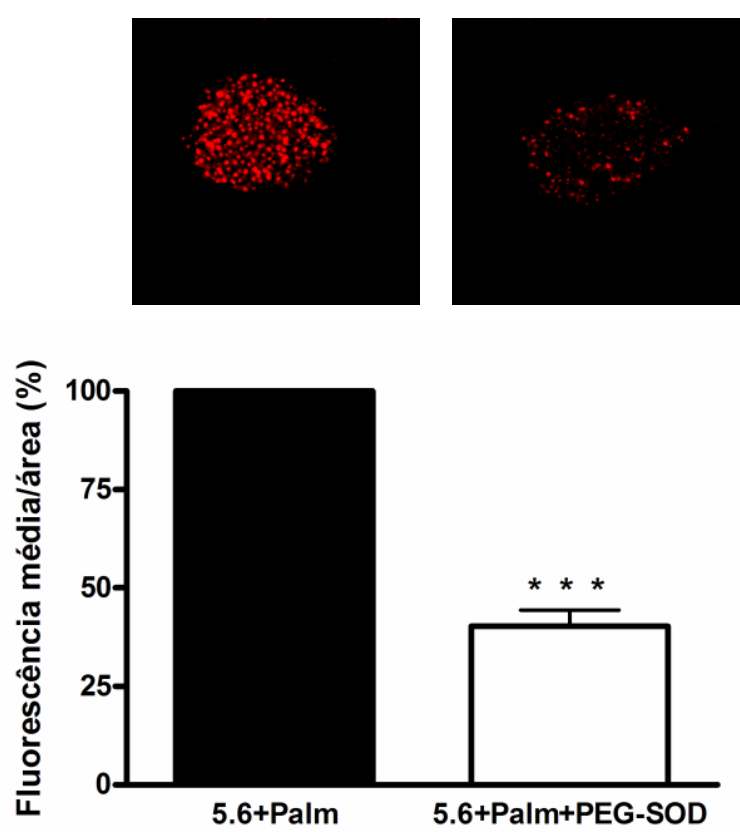

B
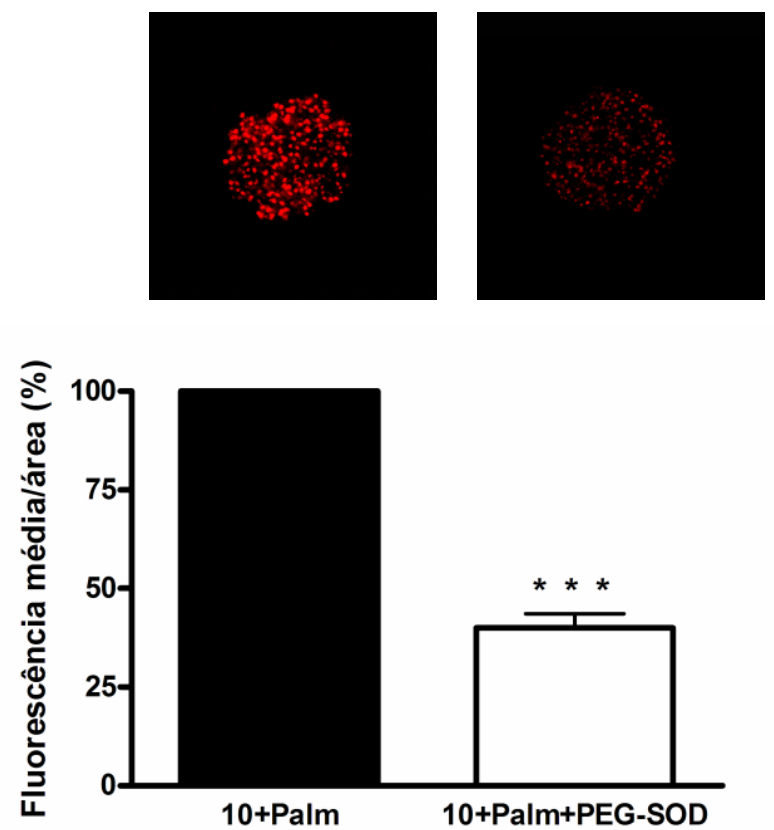

Figura 10 - Efeito da superóxido-dismutase conjugada ao polietilenoglicol (PEG-SOD) no conteúdo de superóxido induzido por palmitato em 5,6 e $10 \mathrm{mM}$ glicose. O conteúdo de superóxido das ilhotas pré-incubadas durante 1 hora em 5,6 mM glicose, na presença ou ausência de PEG-SOD (100 U/mL) e incubadas em 5,6 (A) ou $10(\mathbf{B}) \mathrm{mM}$ glicose na presença de $1 \mathrm{mM}$ palmitato e sob a adição de $100 \mathrm{U} / \mathrm{mL}$ PEG-SOD durante 1 hora foi determinado pelo método da oxidação da diidroetidina $(n=5)$. A intensidade de fluorescência das ilhotas foi analisada utilizando microscopia confocal. Os resultados são expressos em média \pm EP da fluorescência média por área das ilhotas. $* * * \mathrm{P}<0,001$. 


\subsection{Avaliação da secreção estática de insulina}

$\mathrm{Na}$ secreção estática de insulina, observamos a esperada estimulação da secreção induzida pelo palmitato em $10 \mathrm{mM}$ glicose (Figura 11), como demonstrado nas exposições agudas de ilhotas pancreáticas ao ácido graxo na presença de altas concentrações de glicose (CARPINELLI et al., 2002; WARNOTTE et al., 1994). Porém, não foi observada alteração na secreção de insulina na presença do palmitato em 5,6 mM glicose, como também já relatado por vários autores (REMIZOV et al., 2003; WARNOTTE et al., 1994), já que seria necessária a estimulação dos CCDV, os quais somente são induzidos por concentrações acima de 8,3 mM glicose (LEBRUN; MALAISSE; HERCHUELZ, 1983).

A potencialização da secreção de insulina induzida pelo palmitato em $10 \mathrm{mM}$ glicose foi abolida pela incubação com o inibidor DPI (Figura 11). Isto está de acordo com a demonstração de que a inibição da NADPH oxidase com oligonucleotídeo antisense para a subunidade $\mathrm{p} 47^{\text {PHOX }}$ inibiu a secreção de insulina estimulada por $16,7 \mathrm{mM}$ glicose, bem como o DPI foi capaz de reduzir a resposta de cálcio intracelular à glicose (MORGAN et al., 2009). Imoto et al. (2008) na tentativa de elucidar a ação do DPI na redução do processo secretório, testaram os efeitos do fármaco sobre a secreção de insulina estimulada por glicose e outros secretagogos, bem como no cálcio intracelular das células beta pancreáticas. Foi verificado que a ação do DPI está relacionada a uma alteração na sinalização do cálcio, sugerindo a participação da NADPH oxidase na sinalização deste íon nas células beta (IMOTO et al., 2008; MORGAN et al., 2009). Portanto, também o palmitato, ao modular a atividade da enzima, estimularia o processo de secreção de insulina.

Porém, o DPI tem sido demonstrado como um inibidor não específico, já que agiria também no complexo I da cadeia de transporte de elétrons mitocondrial (RAGAN e BLOXHAM, 1977). Tais ações inibitórias advêm da remoção de um elétron de flavoproteínas e a formação de radicais fenil, que inibem os sítios catalíticos das enzimas (O'DONNELL; SMITH; JONES, 1994). Entretanto, estudos anteriores demonstraram que os efeitos da incubação de ilhotas pancreáticas com o DPI são similares aos da inibição da expressão da p4 $7^{\text {PHOX }}$ utilizando-se oligonucleotídeo antisense, levando à redução do conteúdo de superóxido e peróxido de hidrogênio, redução da secreção de insulina induzida pela glicose e oxidação da glicose (MORGAN et al., 2007; MORGAN et al., 2009). 


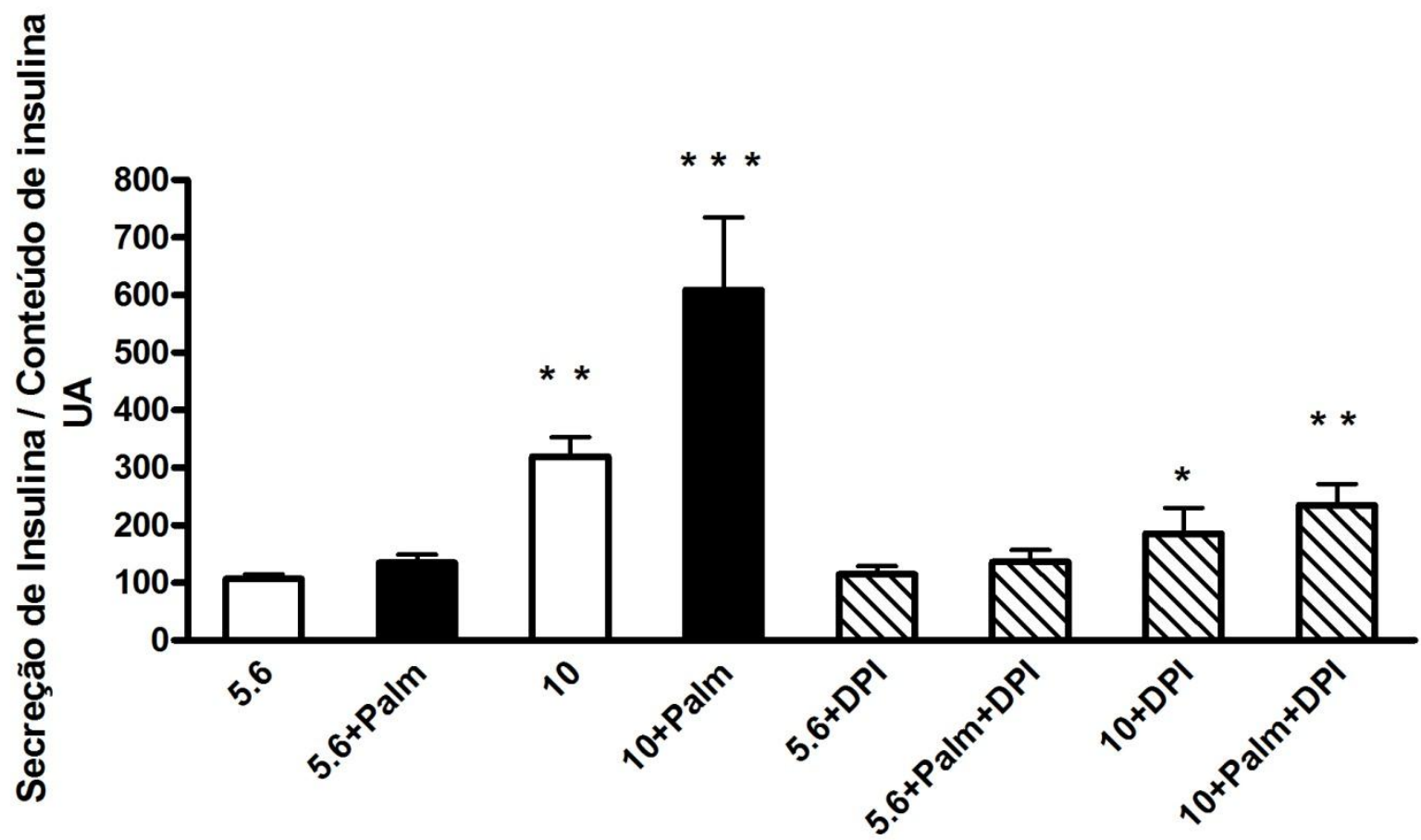

Figura 11 - Secreção de insulina em 5,6 e $10 \mathrm{mM}$ glicose na presença de palmitato e DPI. As ilhotas foram pré-incubadas durante 30 minutos em $5,6 \mathrm{mM}$ glicose e incubadas em 5,6 ou $10 \mathrm{mM}$ glicose, na presença ou ausência de $1 \mathrm{mM}$ palmitato (Palm) e $10 \mu \mathrm{M}$ DPI, durante 1 hora (n=8). A secreção de insulina em cada pool de cinco ilhotas foi normalizada pelo conteúdo de insulina e expressa como porcentagem em relação ao controle $(5,6 \mathrm{mM}$ glicose $)$. Os resultados são expressos em média \pm EP de 5 ilhotas em relação ao controle a $5,6 \mathrm{mM}$ glicose. **P<0,01, ***P<0,001 em relação a 5,6 mM glicose. As condições na presença de DPI são comparadas às respectivas condições na ausência do inibidor. UA: unidade arbitrária. 
Também, a supressão pelo DPI da secreção de insulina estimulada pelo TPA (12-Otetradecanoylphorbol-13-acetate, ativador da PKC) (IMOTO et al., 2008) reforça a hipótese de que aumentos no conteúdo de DAG por diferentes estímulos ativam a PKC e, por consequência, a NADPH oxidase.

Já foi demonstrado que a endotelina aumenta a produção de superóxido em vasos sanguíneos e em cardiomiócitos através da sinalização via receptor $\mathrm{ET}_{\mathrm{A}}$ (receptor associado à proteína $G \alpha_{q}$ ) e pela indução da NADPH oxidase (LI et al., 2003; ZENG et al., 2008). A produção de superóxido derivada da estimulação do complexo NADPH oxidase mostrou-se essencial à ativação dos canais de cálcio do tipo L (CCDV) em cardiomiócitos (ZENG et al., 2008) o que poderia advir do controle redox dos dez resíduos de cisteína presentes no poro desse tipo de canal (MIKAMI et al., 1989). De maneira análoga, a ativação do GPR40 em ilhotas pancreáticas pelo palmitato poderia estimular a atividade da NADPH oxidase, bem como a outras fontes de radicais superóxido, aumentando a concentração intracelular de cálcio por alteração da atividade dos CCDV, assim modulando o processo secretório. Foi demonstrado que o palmitato é capaz de aumentar a entrada de cálcio através do CCDV em ilhotas pancreáticas na presença de altas concentrações de glicose (OLOFSSON et al., 2004b), o que poderia resultar de uma possível regulação redox desse tipo de canal. Logo, seria necessária a pré-ativação desses canais por elevadas concentrações de glicose, para o ácido graxo induzir a potencialização do influxo de cálcio.

Uma constatação da sinalização redox controlando a secreção de insulina é demonstrada no trabalho de Ivarsson e colaboradores, onde é demonstrado que o aumento da relação NADPH/ NADP ${ }^{+}$, também produzida pelo estímulo da glicose, controla o processo de exocitose insulínica. O aumento do NADPH é capaz de modular duas importantes enzimas aceptoras do elétron do NADPH, a glutarredoxina e a tiorredoxina, sendo que a primeira estimularia os efeitos do NADPH na exocitose de grânulos, enquanto a segunda seria responsável pelo efeito inibitório (IVARSSON et al., 2005).

\subsection{Avaliação da translocação da $\mathrm{p} 47^{\mathrm{PHOX}}$ para a membrana plasmática em ilhotas pancreáticas}

Um dos métodos para avaliar a atividade da NADPH oxidase consiste na verificação da migração da subunidade citossólica $\mathrm{p} 47^{\mathrm{PHOX}}$ para as membranas celulares, ativando o complexo enzimático. A p $47^{\mathrm{PHOX}}$ leucocitária torna-se extensivamente fosforilada quando a 
oxidase é ativada (ANDREWS e BABIOR, 1984; HAYAKAWA et al., 1986; HEYWORTH e BADWEY, 1990; KLEINBERG; MALECH; ROTROSEN, 1990; OKAMURA et al., 1988; STEINBECK; HEGG; KARNOVSKY, 1991), porém existem sítios específicos em serina que devem ser fosforilados para que ocorra a ativação da enzima. A p47 ${ }^{\text {PHOX }}$ leucocitária deve, inicialmente, 1) fosforilar-se nos sítios Ser 359 e/ou Ser 370, 2A) haveria a translocação da subunidade $\mathrm{p} 47^{\mathrm{PHOX}}$ parcialmente fosforilada para a membrana, onde $\mathbf{2 B}$ ) a fosforilação dos sítios Ser 303 ou Ser 304 completaria o processo de ativação da $447^{\mathrm{PHOX}}$. A ordem dos passos $2 \mathrm{~A}$ e $2 \mathrm{~B}$ poderia também ocorrer inversamente durante a ativação da enzima (JOHNSON et al., 1998).

Podemos observar pela Figura 12, que tanto em $10 \mathrm{mM}$ glicose, quanto a adição do ácido graxo (palmitato a $1 \mathrm{mM}$ em $1 \%$ albumina) em baixa $(5,6 \mathrm{mM})$ ou alta glicose $(10 \mathrm{mM})$ após 1 hora de incubação induziu uma potencialização da migração da subunidade $\mathrm{p} 47^{\mathrm{PHOX}}$ para a periferia das células da ilhota pancreática. Observamos que tais estímulos proporcionaram uma maior delimitação dos limites celulares em relação ao controle $(5,6 \mathrm{mM}$ glicose), tornando-se mais evidentes os contornos celulares, semelhante ao induzido pelo PMA (phorbol myristate acetate - ativador da PKC) na presença de $10 \mathrm{mM}$ glicose. O PMA, ao ativar a PKC, é capaz de ativar o complexo NADPH oxidase através de fosforilação da p4 $7^{\text {PHOX }}$, aumentando a atividade da enzima e o conteúdo de EROs na ilhota pancreática (OLIVEIRA et al., 2003).

Não podemos descartar a hipótese de que tais observações também sejam resultantes do aumento do conteúdo proteico da subunidade $\mathrm{p} 47^{\mathrm{PHOX}}$, visto que o estudo de Morgan et al. (2007) verificou que a incubação aguda de ilhotas pancreáticas isoladas em altas concentrações de glicose (11,1 e 16,7 mM) ou em concentrações basais $(5,6 \mathrm{mM})$ na presença do palmitato induz aumento do conteúdo proteico da $\mathrm{p} 47^{\mathrm{PHOX}}$ em relação à glicose basal; como também confirmado no presente estudo (Figura 13E). Portanto, nossos dados atuais demonstram que a intensificação da immunorreatividade da $\mathrm{p} 47^{\mathrm{PHOX}}$ nos contornos celulares da ilhota pancreática são indícios de uma maior ativação e até mesmo de uma maior expressão do complexo enzimático. Tais observações colaboram com os dados anteriormente descritos, onde a presença do ácido graxo produz um aumento no conteúdo de radicais superóxido em ilhotas pancreáticas isoladas, o que seria dependente da ativação do complexo NADPH oxidase. 

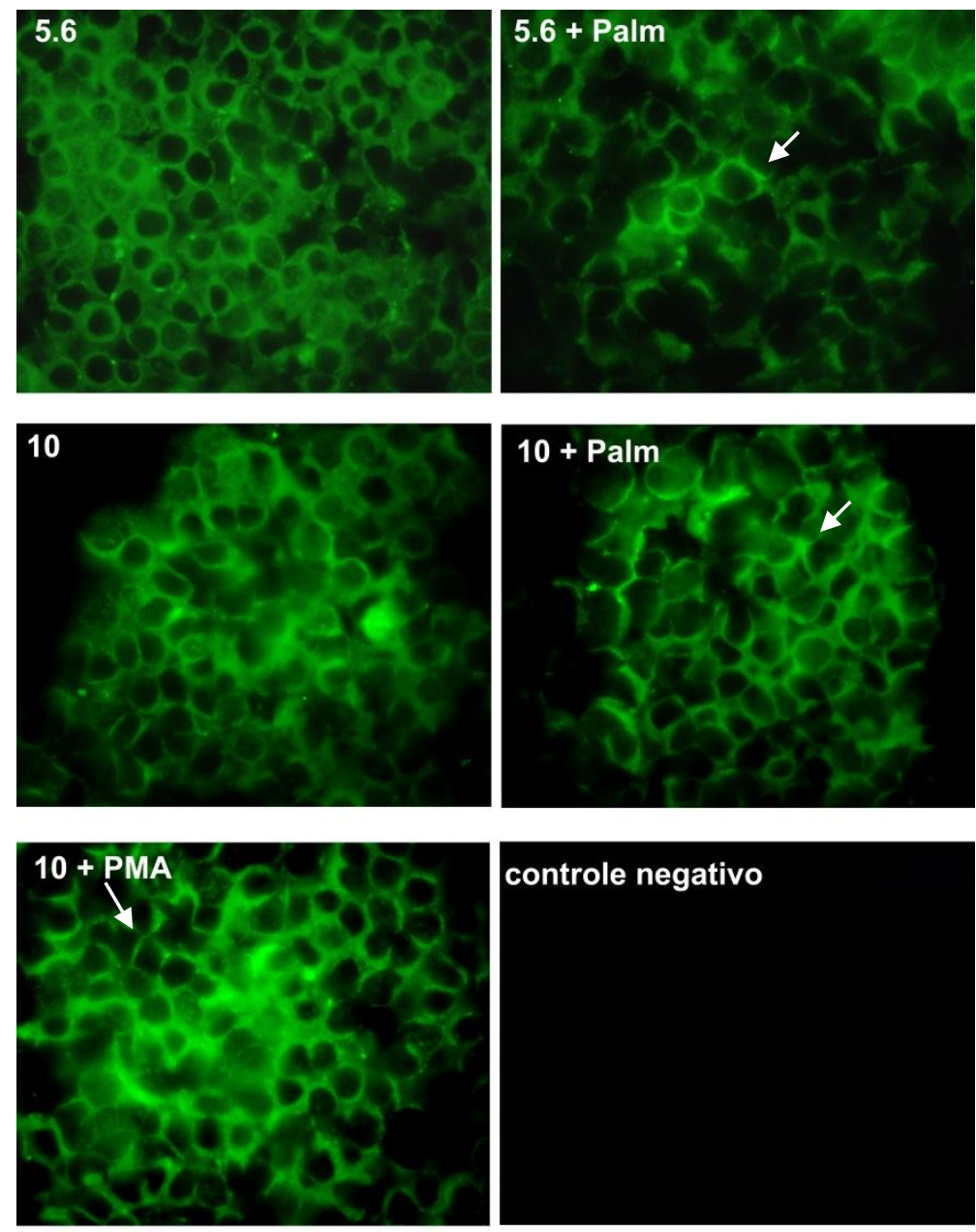

controle negativo

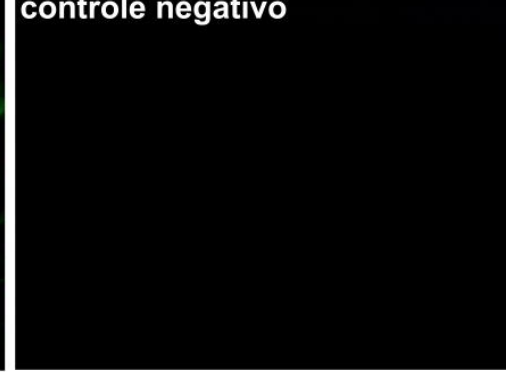

Figura 12 - Avaliação da translocação da subunidade $\mathbf{p 4 7 ^ { \text { PHOx } }}$ por imunofluorescência. Cortes de $12 \mu \mathrm{M}$ de ilhotas pancreáticas isoladas de ratas submetidas à pré-incubação de 30 minutos em 5,6 mM glicose e 1 hora de incubação em 5,6 mM glicose (5,6), 5,6 mM glicose e $1 \mathrm{mM}$ Palmitato (5,6+Palm), 10 $\mathrm{mM}$ glicose (10), $10 \mathrm{mM}$ glicose e $1 \mathrm{mM}$ Palmitato (10+Palm), $10 \mathrm{mM}$ glicose e $20 \mathrm{nM}$ PMA (10+PMA) $(n=4)$. O controle negativo compreende a incubação dos cortes na ausência do anticorpo contra a p $47^{\mathrm{PHOX}}$. As setas indicam regiões com evidenciada translocação da proteína para os limites celulares. 
Em células fagocitárias, a gp91 ${ }^{\text {PHOX }}$ localiza-se tanto intracelularmente quanto na membrana plasmática associada à p22 ${ }^{\mathrm{PHOX}}$ (BORREGAARD et al., 1983). Em neutrófilos em estado não-ativado, a gp91 ${ }^{\text {PHOX }}$ localiza-se em grânulos intracelulares e, sob estimulação, ocorre a translocação da NOX2 na superfície assim que os grânulos se fundem com as membranas de fagossomos ou plasmática (BORREGAARD et al., 1983). Entretanto, foi demonstrado que a NOX2 pode ser ativada dentro dos grânulos, sem ser necessária tal fusão em membranas, culminando em importante produção intracelular de superóxido, responsável pela sinalização intracelular (VAISSIERE; LE CABEC; MARIDONNEAU-PARINI, 1999). Portanto, apesar da migração do complexo enzimático na membrana celular representar importante forma de ativação do seu sítio catalítico, a ativação do complexo poderia ocorrer de maneira também relevante em sítios intracelulares nas células beta, o que impediria uma mais nítida diferenciação da $\mathrm{p} 47^{\mathrm{PHOX}}$ translocada entre as condições com e sem palmitato em alta glicose $(10 \mathrm{mM})$, apesar de havermos detectado diferença na produção de superóxido intracelular nessas situações (Figura 6B).

\subsection{Avaliação da expressão proteica e gênica do GPR40}

Após 1 hora de incubação, não foi observada alteração na expressão proteica do GPR40 em ilhotas pancreáticas (Figura 13A). Este é um período relativamente curto para a ocorrência de nova síntese proteica e, provavelmente, as vias de degradação proteicas não estariam sendo moduladas pela adição do ácido graxo, já que a expressão do GPR40 permanece constante agudamente.

A incubação das ilhotas isoladas durante uma hora na presença de glicose elevada (10 $\mathrm{mM}$ ) e sob a adição do ácido graxo aumentou a expressão gênica do GPR40, sem haver alteração em 5,6 mM glicose (Figura 14A). Isso pode sugerir que o controle transcricional do GPR40 é dependente de elevadas concentrações de insulina e da presença do ácido graxo, como ocorre em $10 \mathrm{mM}$ de glicose na presença do palmitato. Portanto, o ácido palmítico juntamente à glicose ou alta concentração de insulina podem modular positivamente a expressão gênica do receptor, a curto prazo.

Entretanto, foi demonstrado que a exposição de ilhotas humanas provindas de pacientes normais e diabéticos tipo 2 aos ácidos graxos palmitato e oleato durante $24 \mathrm{~h}$ causou redução da expressão gênica do GPR40 nas ilhotas dos diabéticos, bem como causou redução da secreção de insulina estimulada pela glicose em relação aos indivíduos controle (DEL 
GUERRA et al., 2010). Isso demonstra que a exposição aguda ao ácido graxo pode aumentar sua expressão gênica, porém, cronicamente o efeito é inverso. Tal evidência pode relacionar o desenvolvimento do diabetes tipo 2 , onde coexistem altas concentrações séricas de ácidos graxos, glicose e a hiperinsulinemia, com a falha na sinalização intracelular mediada pelo GPR40.

Já foi demonstrado que a incubação de células beta apenas com glicose elevada por até 24 horas não modula a expressão do GPR40, bem como não há alteração da expressão do receptor sob o estímulo de diferentes concentrações de glicose (PAN et al., 2009). Isso reafirma a importância do ácido graxo como elemento modulador da expressão do receptor.

\subsection{Avaliação da expressão, fosforilação e translocação da PKC}

Sendo a atividade do complexo NADPH oxidase, como mostrado em trabalhos anteriores (INOGUCHI et al., 2000; OLIVEIRA et al., 2003), inibida pelo bisindoilmaleimide e sendo este um inibidor de PKCs convencionais e PKCs novas, procuramos investigar a fosforilação, o conteúdo e a translocação das PKCs convencionais $\alpha$ e $\beta I I$.

A fosforilação da PKC constitui-se um processo constitutivo, necessário à maturação da enzima. A PKC recém sintetizada associa-se à membrana em uma conformação aberta, onde o pseudosubstrato é liberado da cavidade de ligação do substrato, o que possibilita a exposição da extremidade C-terminal da enzima, permitindo a ligação da PDK-1 (Phosphoinositide-dependent kinase-1). A PDK-1 fosforila a região de ativação da PKC e é liberada, possibilitando a autofosforilação da PKC por um mecanismo intramolecular. A primeira autofosforilação da PKC ocorre no sítio Thr-641 para a PKC $\beta I I$, sendo isto fundamental à atividade catalítica desta isoforma (KERANEN; DUTIL; NEWTON, 1995). A fosforilação no mesmo sítio na $\mathrm{PKC \alpha}$ (Thr 638) não é requerida para a sua atividade catalítica, mas é importante para a duração da ativação e a taxa de desfosforilação da enzima (BORNANCIN e PARKER, 1996). A enzima fosforilada é liberada no citossol, onde é mantida em uma conformação inativa pela ligação ao pseudosubstrato. Nessa conformação inativa, a PKC é rapidamente desfosforilada, podendo ser refosforilada por outras proteínas, como as chaperonas, adentrando novamente o pool de enzimas competentes para serem ativadas (NEWTON, 2003). 

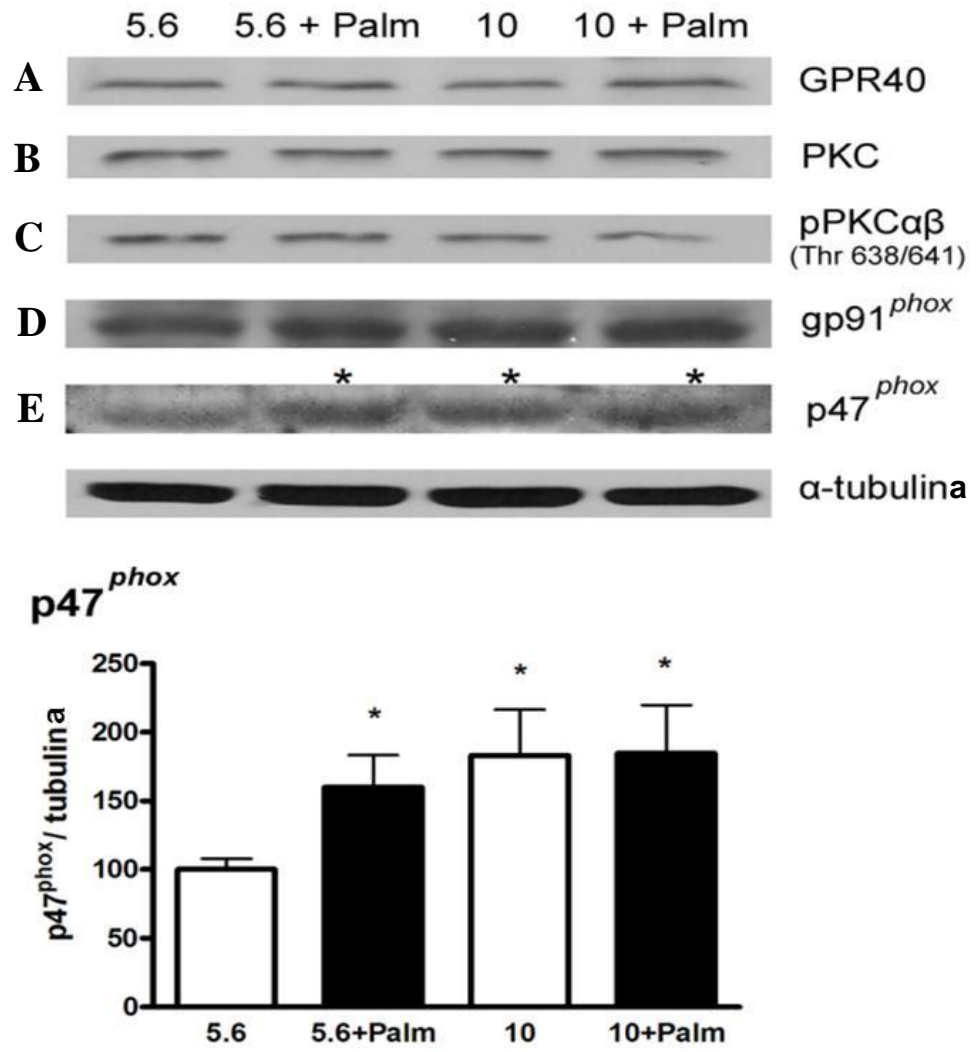

Figura 13 - Expressão proteica do GPR40, conteúdo e fosforilação da PKC e expressão das subunidades gp91 $^{\text {PHOX }}$ e p47 ${ }^{\text {PHOX }}$ da NADPH oxidase. Avaliação da expressão do GPR40 (A), da PKC (B), da fosforilação em treonina das PKC $\alpha$ e $\beta$ II (C) e da expressão das subunidades gp91 ${ }^{\text {PHOX }}$ (D) e $\mathrm{p} 47^{\text {PHOX }}(\mathbf{E})$ da NADPH oxidase em ilhotas pancreáticas isoladas de ratas submetidas à incubação de 1 hora em 5,6 mM glicose $(\mathbf{5 , 6}), 5,6 \mathrm{mM}$ glicose e $1 \mathrm{mM}$ Palmitato (5,6+Palm), $10 \mathrm{mM}$ glicose (10), 10 mM glicose e 1 mM Palmitato (10+Palm) $(n=4$ a 8$)$. $* P<0,05$. 
A

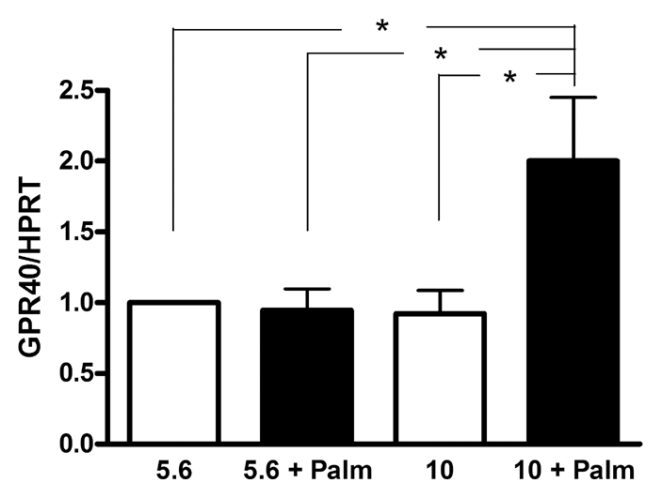

C

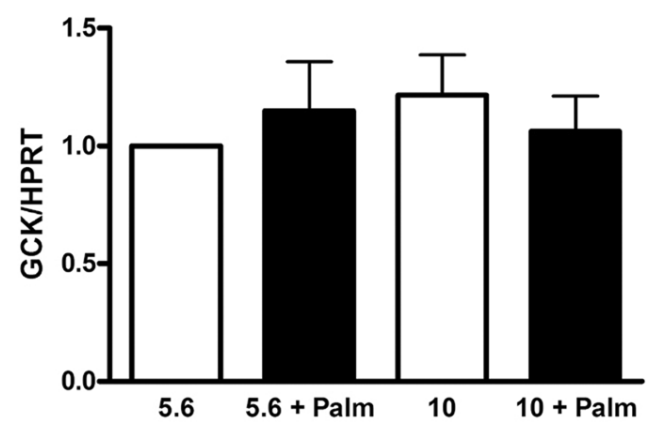

$\mathbf{E}$

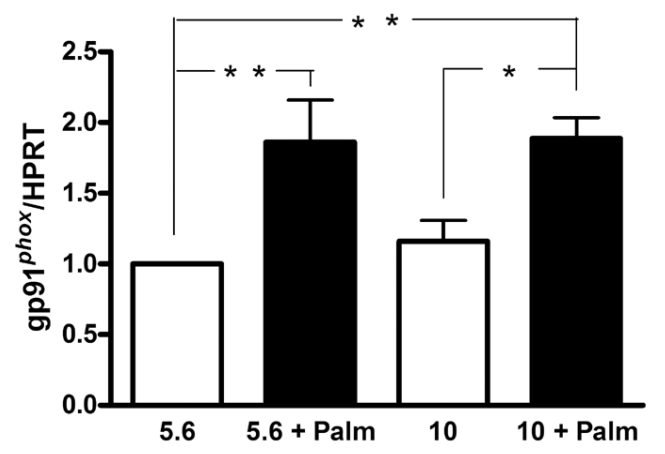

B

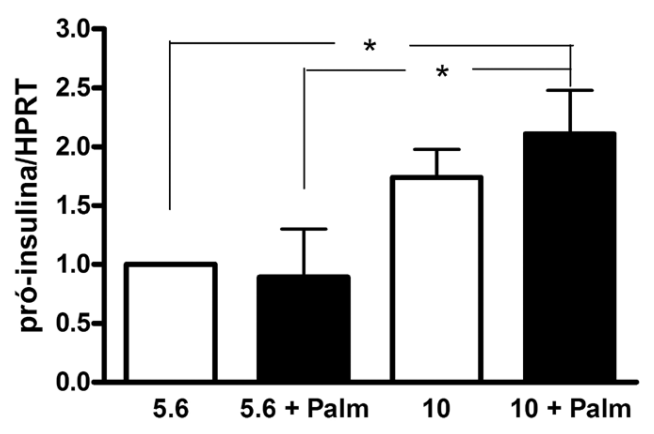

D

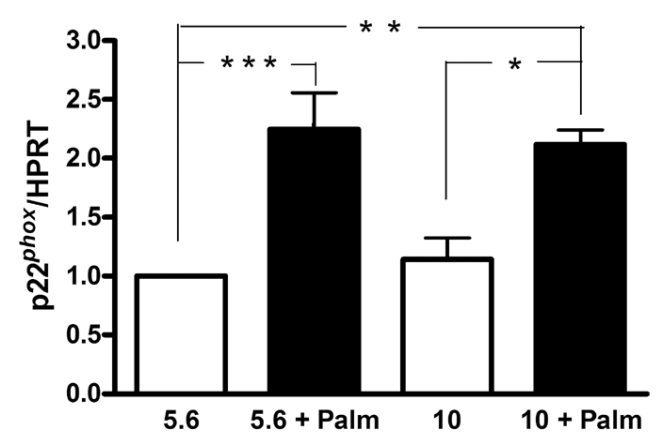

$\mathbf{F}$

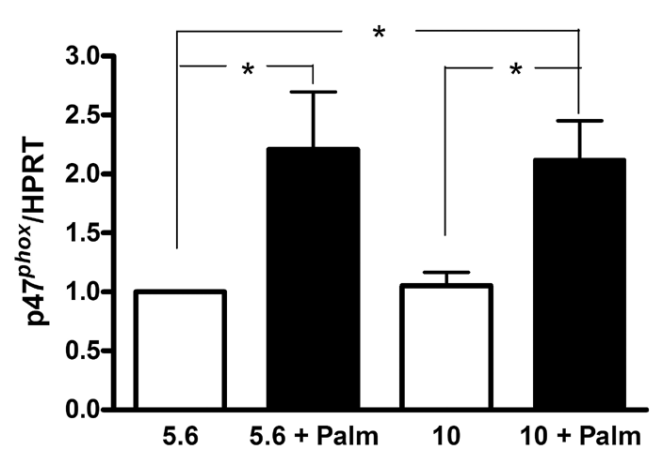

Figura 14- Expressão gênica do GPR40, pró-insulina, glicoquinase e NADPH oxidase. Avaliação da expressão gênica do GPR40 $(\mathbf{A})$, pró-insulina $(\mathbf{B})$, glicoquinase $(\mathbf{C})$ e das subunidades p22 ${ }^{\mathrm{PHOX}}(\mathbf{D})$, gp91 $1^{\text {PHOX }}(\mathbf{E})$ e p $47^{\text {PHOX }}(\mathbf{F})$ por RT-PCR em tempo real em relação ao gene constitutivo HPRT em ilhotas pancreáticas isoladas de ratas submetidas à incubação de 1 hora em 5,6 mM glicose (5,6), $5,6 \mathrm{mM}$ glicose e $1 \mathrm{mM}$ Palmitato (5,6+Palm), $10 \mathrm{mM}$ glicose (10), $10 \mathrm{mM}$ glicose e $1 \mathrm{mM}$ Palmitato (10+Palm) $(\mathrm{n}=6$ a 8$) . * \mathrm{P}<0,05, * * \mathrm{P}<0,01, * * * \mathrm{P}<0,001$. 
Nossos resultados mostram que a expressão da PKC não se encontra alterada pelo estímulo do palmitato em uma hora de incubação (Figura 13B). Nesse caso, utilizamos um anticorpo que não distingue as diferentes isoformas de PKC, dado que já foram identificadas muitas isoformas responsáveis pela ativação do complexo NADPH oxidase em vários tecidos. A fosforilação das isoformas $\alpha / \beta$ II da PKC (Thr 638/641) não é alterada durante uma hora de incubação sob as diferentes concentrações de glicose e sob a adição do ácido graxo (Figura 13C), o que indica que o processo de maturação da enzima não é alterado agudamente por tais estímulos. Porém, ao avaliarmos a distribuição das PKCs $\alpha$ e $\beta$ por imunofluorescência, observamos que a adição do ácido graxo está aumentando o seu teor de migração para a periferia celular em relação a 5,6 mM glicose. A incubação em alta glicose sozinha (10 mM) produziu uma potente evidenciação das membranas plasmáticas celulares (Figura 15).

A translocação para a membrana plasmática das PKC $\alpha$ e $\beta I I$ induzida agudamente pela glicose já foi descrita em trabalhos anteriores (GANESAN et al., 1992; WARWAR et al., 2006; YEDOVITZKY et al., 1997; ZHANG et al., 2004), cuja inibição estaria associada à atenuação da estimulação da secreção de insulina induzida pela glicose (YEDOVITZKY et al., 1997). Nossos resultados atuais colaboram com tais evidências e acrescentam que o ácido graxo também pode induzir tal translocação, o que pode representar um elemento contribuinte à produção citossólica de superóxido induzida pela NADPH oxidase (Figuras 6 e 9).

A glicose é um importante ativador da PKC ao induzir um marcante aumento da malonil-CoA, a qual inibe a atividade da CPT-I e, portanto, a oxidação dos ácidos graxos intracelulares. Consequentemente, a LC-CoA acumula-se no citoplasma e se combina ao glicerol-fosfato formando DAG, o qual é capaz de ativar a PKC (PRENTKI e MATSCHINSKY, 1987; WOLLHEIM e SHARP, 1981; ZAWALICH e RASMUSSEN, 1990). Logo, a glicose, ao ativar a PKC, seria capaz de ativar o complexo NADPH oxidase, aumentando o conteúdo celular de superóxido, como demonstrado (MORGAN et al., 2007; MORGAN et al., 2009). Além disso, altas concentrações de glicose ativam potencialmente os CCDV (ZHANG et al., 2003), estimulando o influxo de cálcio e, por consequência, a ativação das PKCs convencionais. Também, a presença de glicose em ilhotas pancreáticas isoladas causa um significativo aumento do conteúdo de ácidos graxos que são exportados ao meio de incubação, dentre eles o palmítico e o esteárico (MARTINS et al., 2004), que poderiam exercer uma ação parácrina ou autócrina ativando o receptor GPR40 e potencializando a secreção de insulina induzida pela própria glicose. Já o palmitato, ao ativar a via de 
sinalização induzida pelo GPR40, estimula a PLC levando à produção de $\mathrm{IP}_{3}$, que recruta $\mathrm{o}$ cálcio reticular, e DAG, elementos essenciais à ativação das PKCs novas e convencionais.

$\mathrm{Na}$ presença de alta glicose, o acúmulo de LC-CoA oriundo dos ácidos graxos é também um importante elemento sinalizador para a ativação de PKC. Além disso, já foi demonstrado que o palmitato é capaz de potencializar atividade de CCDV em ilhotas de camundongos principalmente em concentrações elevadas de glicose (OLOFSSON et al., 2004a; WARNOTTE et al., 1994), aumentando o influxo de cálcio, que pode estar diretamente associado à ativação da $\mathrm{PKC}$ e, consequentemente, à ativação do complexo NADPH oxidase. Além disso, foi demonstrado em ilhotas pancreáticas de rato que o palmitato estimula a translocação da PKC da região citossólica para a fração de membrana em concentrações de $20 \mathrm{mM}$ de glicose e que tal translocação era dependente da síntese de derivados lipídicos. Nesse sentido, o DAG e a fosfatidilserina, gerados secundariamente à administração exógena de palmitato seriam, portanto, necessários à ativação da PKC (ALCAZAR et al., 1997).

Em monócitos humanos, os ácidos graxos ativam diretamente a $\mathrm{PKC}$, produzindo simultaneamente a fosforilação e translocação da subunidade $\mathrm{p} 47^{\mathrm{PHOX}}$ para a membrana plasmática (KADRI-HASSANI; LEGER; DESCOMPS, 1995), como observado em nossos experimentos (Figura 12) e em estudo prévio utilizando a incubação de células de ilhotas dispersas com glicose (OLIVEIRA et al., 2003). 

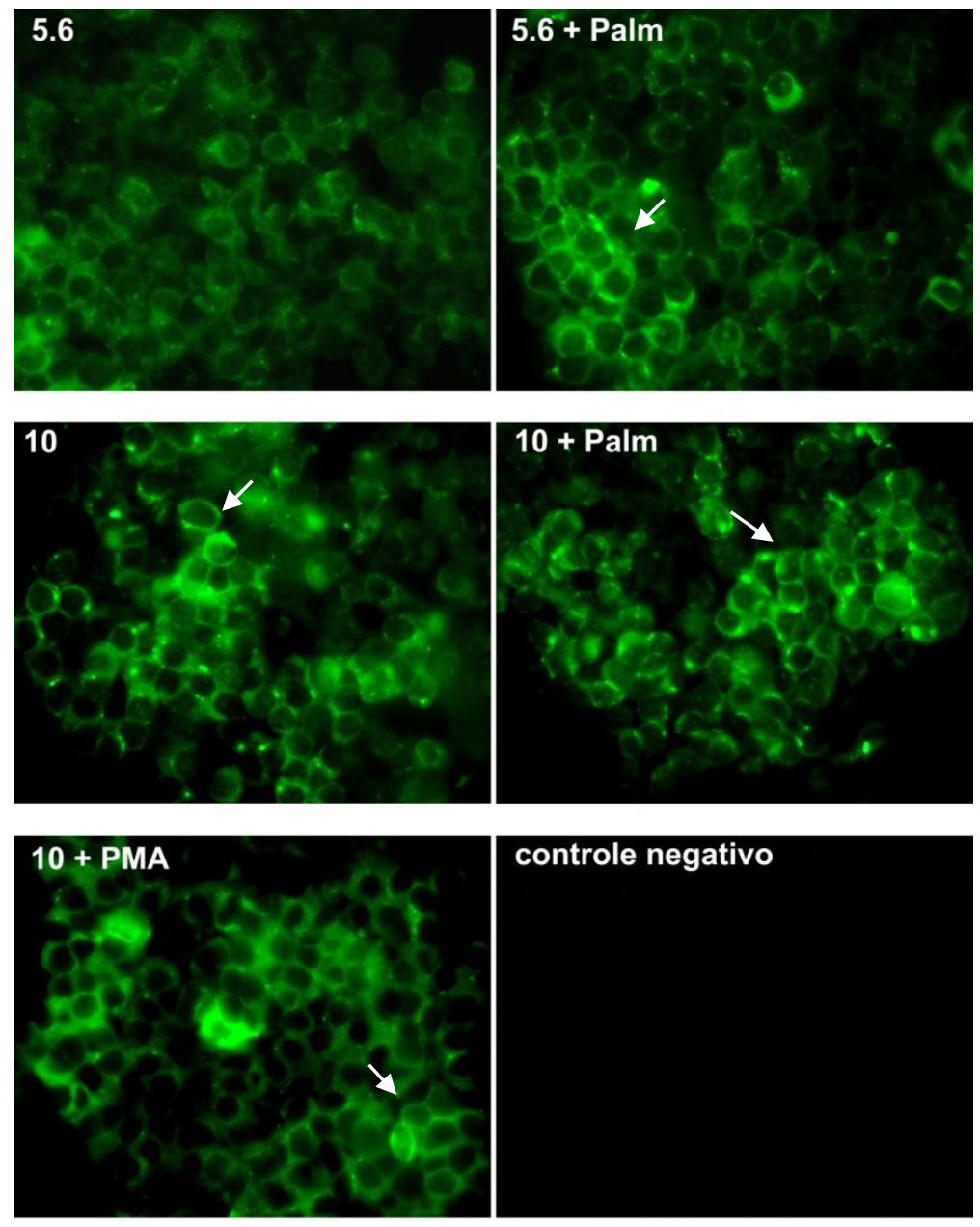

Figura 15 - Avaliação da translocação das PKCs $\boldsymbol{\alpha}$ e $\boldsymbol{\beta}$ II por imunofluorescência. Cortes de $12 \mu \mathrm{M}$ de ilhotas pancreáticas isoladas de ratas submetidas à pré-incubação de 30 minutos em 5,6 mM glicose e 1 hora de incubação em 5,6 mM glicose (5,6), 5,6 mM glicose e 1 mM Palmitato (5,6+Palm), 10 $\mathrm{mM}$ glicose (10), $10 \mathrm{mM}$ glicose e $1 \mathrm{mM}$ Palmitato (10+Palm), e $10 \mathrm{mM}$ glicose e $20 \mathrm{nM}$ PMA (10+PMA) $(n=4)$. O controle negativo compreende a incubação dos cortes na ausência do anticorpo contra as PKCs. 


\subsection{Avaliação da expressão gênica da pró-insulina e da glicoquinase}

A análise da expressão do gene da pró-insulina (Figura 14B) demonstrou-nos que, já agudamente, em uma hora de incubação, a expressão é estimulada pela presença de glicose elevada (10 mM), o que também ocorre na incubação do palmitato em $10 \mathrm{mM}$ de glicose. Isso decorre do controle da demanda de insulina, que está aumentada nessas condições, tornandose necessária uma maior transcrição gênica, que pode também estar associada a uma maior tradução de cada RNA mensageiro. Tudo isso induziria uma maior biossíntese do hormônio, para a manutenção do aumento da demanda.

Já a expressão do RNAm da glicoquinase, enzima chave do processo de oxidação de glicose, não é modulada agudamente pelo palmitato (Figura 14C). Portanto, o ácido graxo não atuaria modulando agudamente sua expressão gênica, apesar de já ter sido demonstrado que o processo de oxidação preferencial de glicose ou ácido graxo é modificado segundo as diferentes concentrações de glicose (CARPINELLI et al., 2002).

\subsection{Avaliação da expressão proteica e gênica dos componentes da NADPH oxidase}

Observamos que o palmitato induziu aumento na expressão gênica da p22 ${ }^{\mathrm{PHOX}}$, da gp91 ${ }^{\text {PHOX }}$ e da p47 $7^{\text {PHOX }}$ em uma hora de incubação em 5,6 e em $10 \mathrm{mM}$ glicose, como demonstrado na Figura 14 D, E, F. Isso nos sugere que, já a curto prazo, pode ocorrer um aumento da expressão proteica da enzima, como já evidenciado em estudo anterior, ao ser avaliada a expressão da $47^{\text {PHOX }}$ induzida por glicose e palmitato (MORGAN et al., 2007). Confirmamos no presente estudo que a expressão proteica da subunidade $\mathrm{p} 47^{\mathrm{PHOX}}$ é modulada pelo ácido graxo e por alta glicose (Figura 13E), porém a subunidade gp91 ${ }^{\mathrm{PHOX}}$ não se apresenta alterada (Figura 13D), tanto a sua forma glicosilada, demonstrada na figura, quanto a sua forma não glicosilada, com menor peso molecular. Já foi demonstrado que a expressão de vários componentes da NADPH oxidase é induzível e regulada por fatores repressores e ativadores. Como exemplo, a expressão de gp91 ${ }^{\text {PHOX }}$ é aumentada em resposta à angiotensina II em diversos tecidos, inclusive nas ilhotas pancreáticas (NAKAYAMA et al., 2005). Um importante fator ativador da expressão da NADPH oxidase é o fator nuclear kapa B (NF- $\kappa \mathrm{B})$ (ANRATHER; RACCHUMI; IADECOLA, 2006), o qual é potencialmente ativado por ácidos graxos e capaz de aumentar a expressão gênica da gp91 ${ }^{\mathrm{PHOX}}, \mathrm{p} 47^{\mathrm{PHOX}}$ e $\mathrm{p} 67^{\mathrm{PHOX}}$ (GAUSS et al., 2007). Já foi demonstrado que o aumento da expressão da $47^{\mathrm{PHOX}}$ também está associado 
às mudanças da fosforilação e afinidade do fator ativador PU.1, um fator transcricional para diferenciação de macrófagos e hematopoiese (MARDEN et al., 2003).

\subsection{Uso da linhagem INS-1E}

Com o intuito de avaliar o bloqueio da expressão do GPR40 com o sistema de RNAi, optamos por realizar o bloqueio por RNAi em linhagem clonal de insulinoma de rato, INS-1E. A linhagem INS-1E, derivada da linhagem parental INS-1, foi selecionada devido ao seu conteúdo de insulina, responsividade à glicose, adequada proliferação e a já demonstrada expressão do GPR40 (SHAPIRO et al., 2005; STODDART; BROWN; MILLIGAN, 2007; YANG et al., 2009).

\subsubsection{Avaliação dos componentes da NADPH oxidase em linhagem INS-1E}

Para validar a aplicabilidade do uso da linhagem INS-1E como modelo para avaliar a possível função do GPR40 como regulador da secreção de insulina e produção de radicais superóxido, avaliamos a expressão proteica dos componentes $\mathrm{p} 47^{\mathrm{PHOX}}, \mathrm{gp} 91^{\mathrm{PHOX}}$ e $\mathrm{p} 22^{\mathrm{PHOX}} \mathrm{da}$ NADPH oxidase (Figura 16). Já havia sido descrita a expressão do RNA mensageiro da p47 $7^{\text {PHOX }}$ em linhagem INS-1E, onde a alta concentração de glicose induziu aumento da expressão gênica dessa subunidade (LEUNG e LEUNG, 2008). Observamos também a expressão da subunidade $\mathrm{p} 22^{\mathrm{PHOX}}$, porém comparativamente em menor magnitude do que o observado em ilhotas pancreáticas.

A subunidade gp91 ${ }^{\text {PHOX }}$ fica evidenciada em uma banda para as ilhotas pancreáticas e INS-1E em altura próxima aos $55 \mathrm{KDa}$ e outra entre os $75 \mathrm{KDa}$ e $90 \mathrm{KDa}$ (Figura 16). Isso,

pois a gp91 ${ }^{\text {PHOX }}$ é uma proteína altamente glicosilada, que aparece como uma ampla mancha de bandas nas corridas por SDS-PAGE, o que reflete a heterogeneidade de glicosilação. A forma mais glicosilada possui o peso molecular aparente de 70 a $90 \mathrm{KDa}$. Já a remoção dos carboidratos pela endoglicosidase $\mathrm{F}$ produz uma proteína com peso molecular de $55 \mathrm{KDa}$, demonstrando a extensão de glicosilação. As cadeias de carboidratos são compostas por Nacetilglicosamina e galactose e, em menor extensão, por frutose, manose e glicose (HARPER; CHAPLIN; SEGAL, 1985). Tais carboidratos são ligados aos resíduos de asparagina (132Asn, 149Asn, 240Asn) no segundo e terceiro loops extracelulares preditos à 


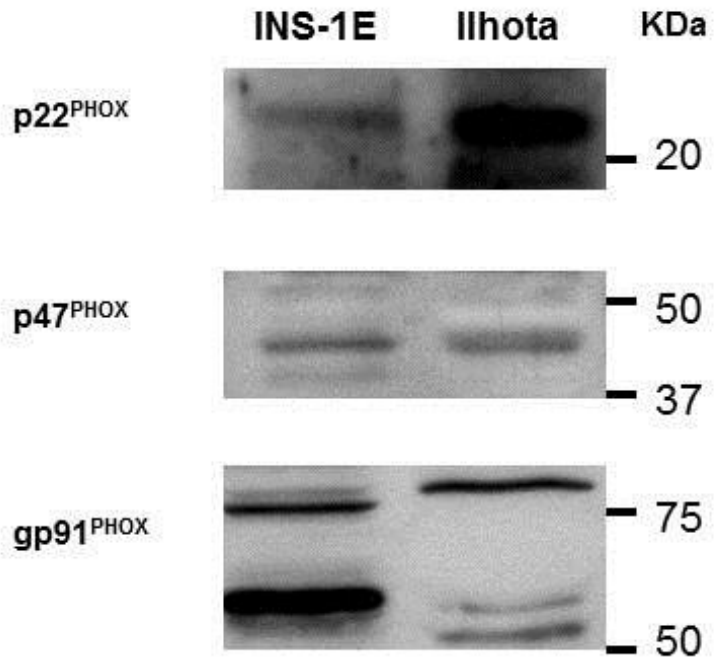

Figura 16 - Expressão proteica das subunidades $\mathrm{p2}^{\mathrm{PHOx}}, \mathrm{p} 47^{\mathrm{PHOx}}$ e gp91 ${ }^{\mathrm{PHOx}}$ da NADPH oxidase em linhagem INS-1E. Avaliação da expressão proteica da $\mathrm{p} 22^{\mathrm{PHOX}}, \mathrm{p} 47^{\mathrm{PHOX}}, \mathrm{gp} 91^{\mathrm{PHOX}}$ em linhagem de células INS-1E, derivada de insulinoma de rato, cultivada em meio RPMI em 11,1 mM glicose. A subunidade gp91 ${ }^{\mathrm{PHOX}}$ é demonstrada em sua forma mais glicosilada, de peso molecular superior a 75 $\mathrm{KDa}$, e menos glicosilada, de peso molecular próximo a $55 \mathrm{KDa}$. Utilizamos o controle de extratos proteicos de ilhotas pancreáticas para demonstrar a expressão das subunidades. 
subunidade, já que não existe o estudo cristalográfico da enzima (WALLACH e SEGAL, 1997). A função da extensiva glicosilação não é bem conhecida, embora tenha sido demonstrado que esteja envolvida no dobramento da proteína e sua estabilidade, prevenindo a transição do complexo de seu estado de repouso para o ativo, sob a estimulação celular (DELEO et al., 2000; PACLET et al., 2001).

\subsubsection{Avaliação do conteúdo de superóxido em linhagem INS-1E na presença de palmitato, PEG-SOD e DPI}

Para avaliar os efeitos do palmitato em concentrações basais e altas de glicose, buscamos partir de extremos maiores de glicose $(2,8$ e $16,7 \mathrm{mM})$, visto que esse tipo de linhagem é normalmente cultivado em 11,1 mM glicose e, portanto, a concentração de glicose utilizada em ilhotas pancreáticas $(10 \mathrm{mM})$ não representaria um tão potente estímulo à secreção de insulina nesse tipo de célula.

De maneira análoga ao observado em ilhotas pancreáticas isoladas, o palmitato induz aumento proeminente (cerca de 7 vezes) no conteúdo de superóxido em 2,8 $\mathrm{mM}$ glicose, o que é reduzido em 55\% pela incubação com PEG-SOD (Figura 17A). Já em 16,7 mM glicose, o ácido graxo produziu aumento de 38,5\% no conteúdo de superóxido, o que fora bloqueado em 68\% pela incubação com PEG-SOD (Figura 17B). Ao compararmos as condições expostas ao ácido graxo, a produção de superóxido é $90 \%$ inferior em 16,7 em relação a 2,8 mM glicose (Figura 18). Assim, como anteriormente discutido em ilhotas pancreáticas, tais resultados provavelmente se devem à importância da beta-oxidação como fonte produtora de radicais superóxido em situações de baixa glicose (CARPINELLI et al., 2002; HELLEMANS et al., 2007) e da ativação da enzima antioxidante Cu/Zn-SOD em situações de alta glicose (OLIVEIRA; CURI; CARPINELLI, 1999). Os efeitos na produção de superóxido observados nas ilhotas pancreáticas mostraram-se mais evidentes na linhagem permanente, havendo uma maior produção de superóxido induzida pelo palmitato em baixa glicose e uma semelhança ao observado em alta glicose. Tal evidência pode advir da maior adaptação das defesas antioxidantes da linhagem em concentrações elevadas de glicose, visto que esse tipo celular é cultivado a 11,1 mM glicose. Outros fatores também associados podem ser o uso de maiores extremos nas concentrações de glicose empregadas e da ausência de fatores para inibir os efeitos da insulina, como os demais hormônios secretados pelo pâncreas endócrino, bem como a somatostatina. 
A
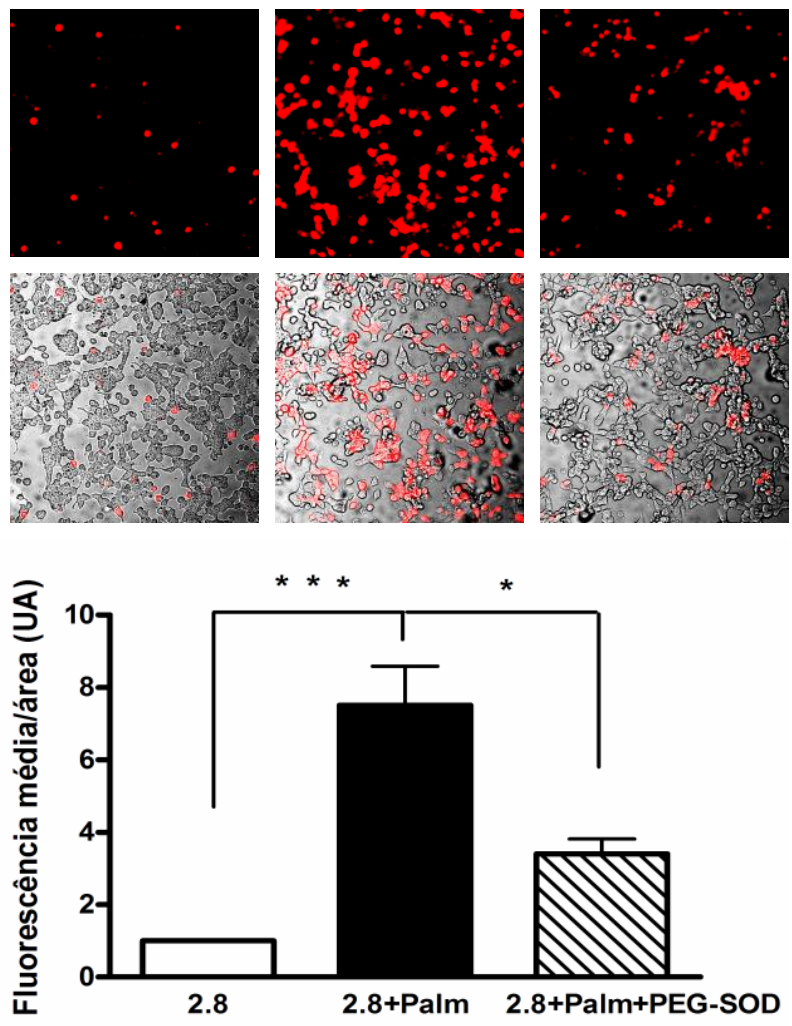

B
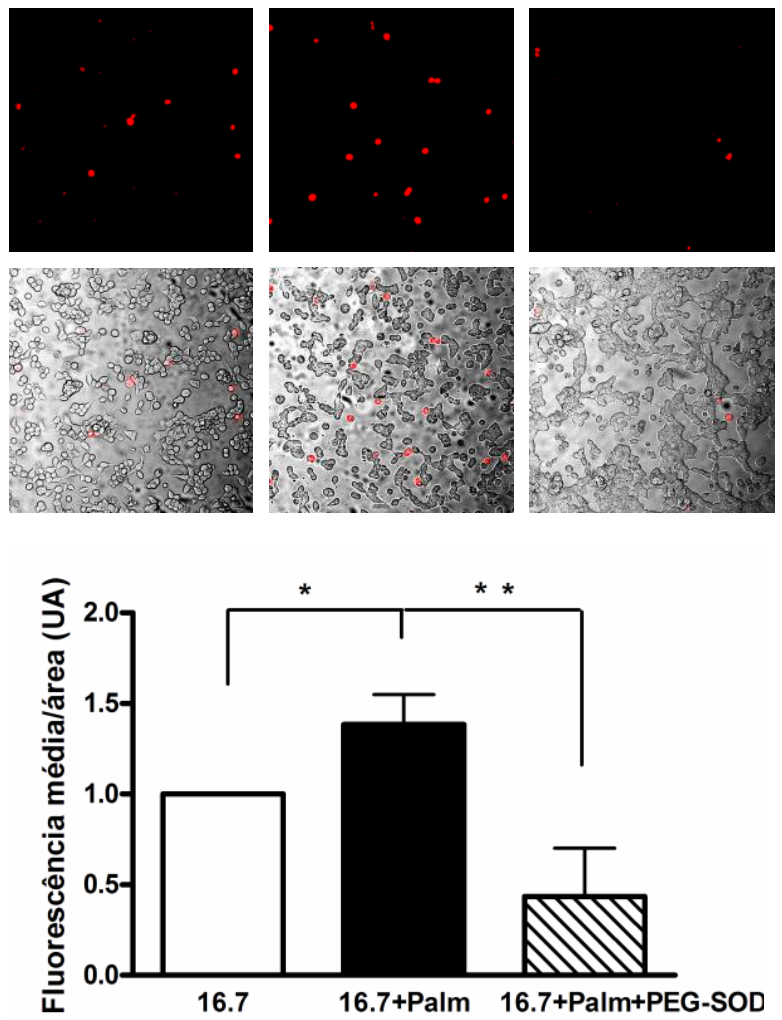

Figura 17 - Conteúdo de superóxido induzido pelo palmitato em 2,8 (A) e $16,7 \mathrm{mM}$ (B) glicose e sob a adição de 100 U/mL PEG-SOD em linhagem INS-1E. A. O palmitato induz aumento da produção de superóxido em cerca de 7 vezes em 2,8 mM glicose, o que é reduzido em $55 \%$ pela incubação com PEG-SOD. B. O palmitato induz aumento de 38,5\% no conteúdo de superóxido em $16,7 \mathrm{mM}$ glicose, sendo reduzido em $68 \%$ pela incubação com PEG-SOD. Nos planos superiores das figuras são demonstradas as imagens de fluorescência e logo abaixo as respectivas imagens de microscopia de luz sobrepostas. $* \mathrm{P}<0,05$, $* * \mathrm{P}<0,01 \mathrm{e} * * * \mathrm{P}<0,001$. 

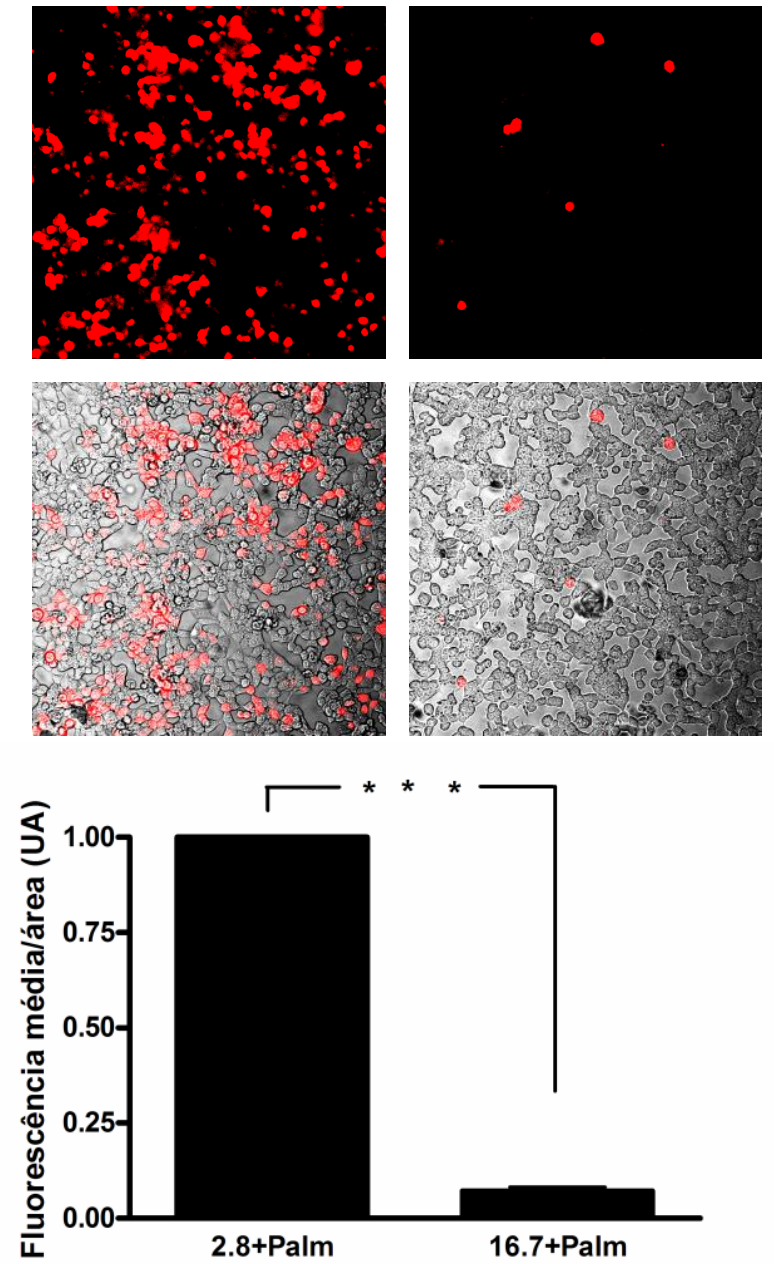

Figura 18 - Conteúdo de superóxido induzido pelo palmitato em 2,8 e 16,7 mM glicose em linhagem INS1E. O conteúdo de superóxido na presença do ácido graxo em $16,7 \mathrm{mM}$ glicose é reduzido em $90 \%$ em relação à condição em $2,8 \mathrm{mM}$ glicose. No plano superior da figura são demonstradas as imagens de fluorescência e logo abaixo as respectivas imagens de microscopia de luz sobrepostas. $* * * \mathrm{P}<0,001$. 
O inibidor da NADPH oxidase DPI reduziu em 43\% o conteúdo de superóxido na presença do palmitato em 2,8 mM glicose e inibiu em 36\% em 16,7 mM glicose na presença do palmitato (Figura 19), o que evidencia a importância do palmitato como indutor do complexo enzimático também na linhagem secretora de insulina e na ausência de outros tipos celulares.

\subsubsection{Avaliação do bloqueio da expressão do GPR40 por RNAi}

Através dos estudos com RNAi contra o GPR40, conseguimos avaliar que das três sequências antisense (AS) utilizadas para inibir a expressão proteica do receptor, a sequência AS2 apresentou-se mais eficaz, produzindo 54\% de inibição da expressão do GPR40 em 48h de incubação (Figura 20A). O controle negativo (C) apresenta uma sequência não consensual a qualquer sequência do transcriptoma de vertebrados e é utilizada na mesma concentração que a utilizada para o antisense, sendo empregada como controle da reação.

Observamos que o tratamento por RNAi não alterou a fragmentação de DNA (C: 95,5\% \pm 0,06; AS: 95,4 \% $\pm 0,21$ de células sem fragmentação de DNA, $\mathrm{n}=3$ experimentos independentes), fenômeno normalmente associado a eventos apoptóticos. A viabilidade celular também não foi alterada (C: 94,3\% \pm 0,11; AS: 93,2\% \pm 1,32 de células viáveis, $n=3$ ), demonstrando a integridade da membrana plasmática celular. Logo, o processo de inibição proteica do receptor não modulou os eventos associados a apoptose ou necrose celular.

Observamos que o bloqueio da expressão do GPR40 induziu a inibição em 23\% da expressão da SOD-1 ou Cu/Zn-SOD (Figura 20B), o que pode ser um elemento limitante no controle da dismutação do superóxido a peróxido de hidrogênio. Ao avaliarmos a expressão das subunidades $\mathrm{p} 47^{\text {PHOX }}$ e gp91 ${ }^{\text {PHOX }}$ (Figura 20C), observamos que não houve alteração do seu conteúdo proteico por meio da inibição da expressão do GPR40. No caso específico de gp91 ${ }^{\text {PHOX }}$, avaliamos o seu padrão de glicosilação, através da mensuração das banda de peso molecular aproximado de 75-100 KDa (forma glicosilada) e $55 \mathrm{KDa}$ (forma não-glicosilada) e observamos que os padrões de glicosilação também não se mostraram alterados entre as condições. Logo, a inibição da expressão do GPR40 não causa alteração no padrão de expressão das subunidades da NADPH oxidase. 
A
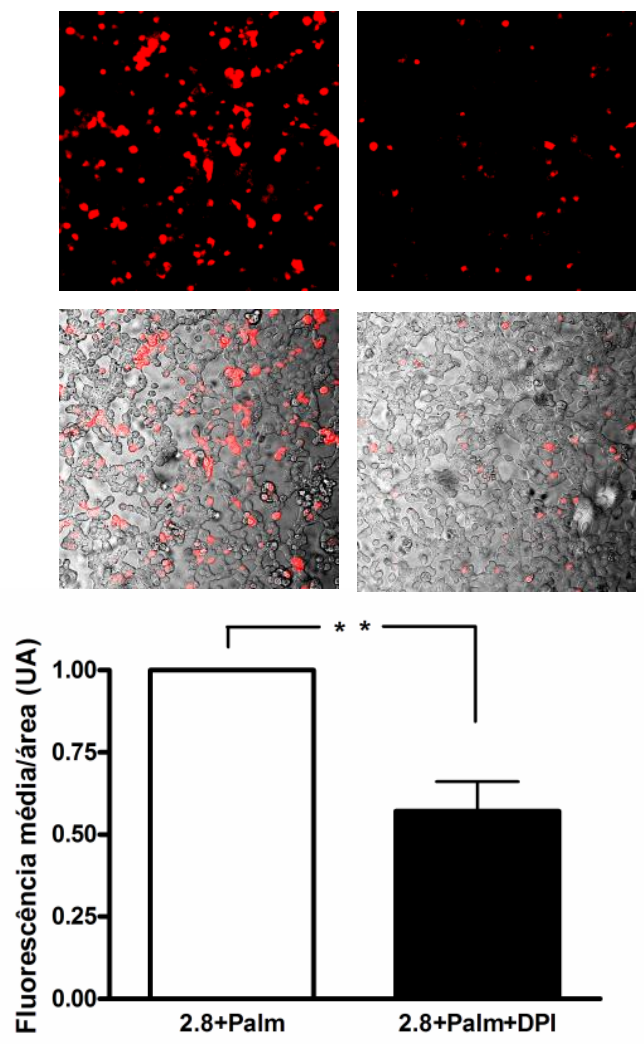

B
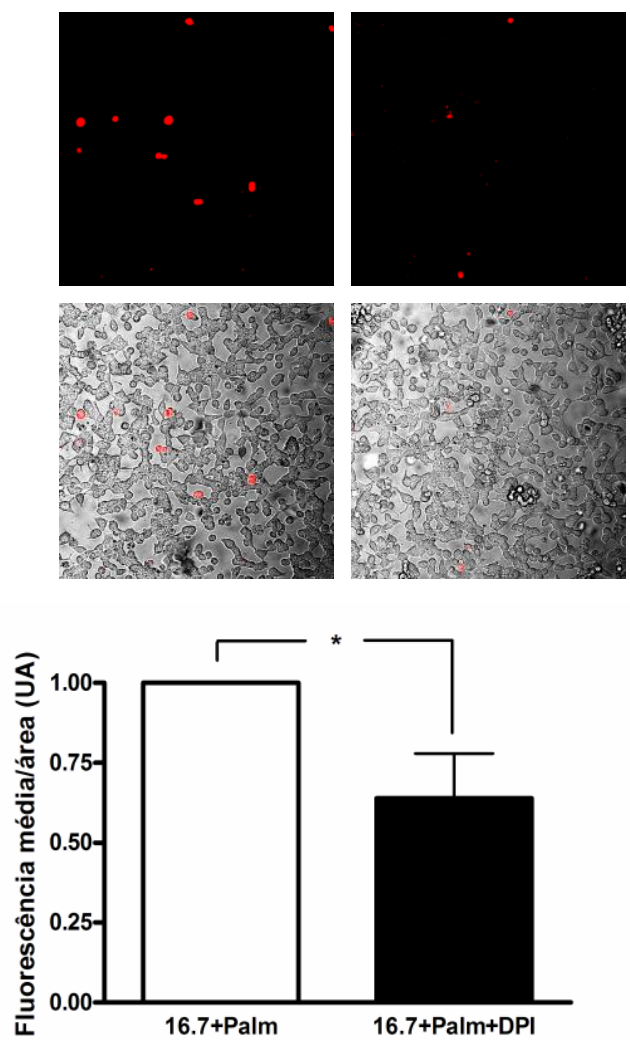

Figura 19 - Conteúdo de superóxido induzido pelo palmitato em 2,8 (A) e 16,7 $\mathrm{mM}$ (B) glicose e sob a adição de 50 nM DPI em linhagem INS-1E. A. O inibidor da NADPH oxidase reduz em $43 \%$ o conteúdo de superóxido na presença do palmitato em 2,8 mM glicose. B. Em 16,7 mM glicose, o DPI inibiu em $36 \%$ o conteúdo de superóxido na presença do ácido palmítico. Nos planos superiores das figuras são demonstradas as imagens de fluorescência e logo abaixo as respectivas imagens de microscopia de luz sobrepostas. $* \mathrm{P}<0,05, * * \mathrm{P}<0,01$. 
A

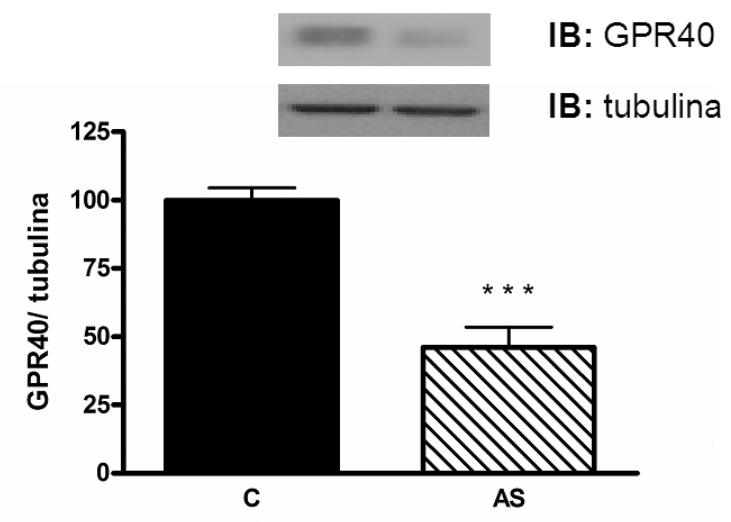

B

IB: SOD-1

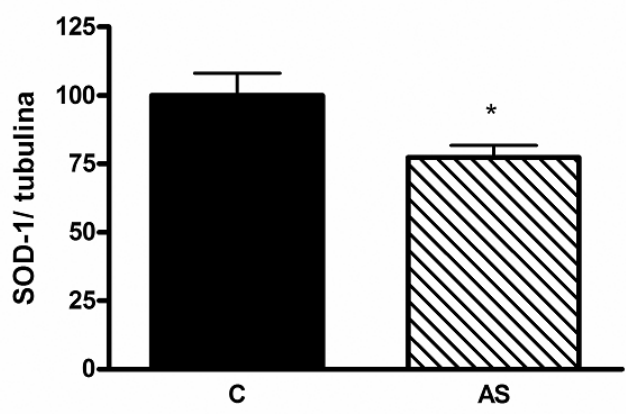

C

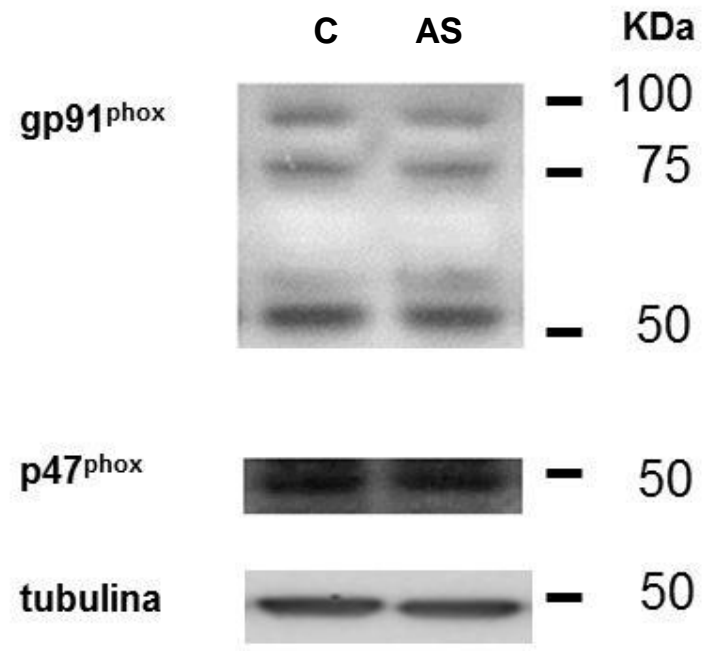

Figura 20 - Expressão proteica do GPR40, SOD-1 e NADPH oxidase em linhagem INS-1E submetida à transfecção com RNAi contra GPR40. Avaliação da expressão proteica do GPR40 (A), de SOD-1 (B), gp91 ${ }^{\text {PHOX }}$ e p47 ${ }^{\text {PHOX }}(\mathbf{C})$ em controle negativo $(\mathbf{C}$, contendo sequência não consensual a qualquer sequência do transcriptoma de vertebrados) e em incubação com a sequência antisense (AS, contra o GPR40 do rato) após 48 horas. A expressão do GPR40 foi 54\% reduzida com o tratamento com o RNAi, induzindo também a redução da expressão proteica da SOD-1 em $23 \%$ $(\mathrm{n}=5) . * \mathrm{P}<0,05, * * * \mathrm{P}<0,001$. 


\subsubsection{Avaliação do conteúdo de superóxido em linhagem INS-1E após inibição da expressão do GPR40}

O uso do RNAi contra o GPR40 inibiu em 33\% o conteúdo de superóxido em 2,8 mM glicose na presença do ácido palmítico (Figura 21A). Tal resultado destaca a participação da sinalização mediada pela ativação do GPR40, controlando a produção de superóxido. A ativação do receptor pelo palmitato poderia modular a atividade da PKC, como já anteriormente verificado no estudo de translocação das isoformas $\alpha$ e $\beta I I$ e na produção de superóxido em ilhotas pancreáticas (Figuras 15 e 9, respectivamente). Ao reduzir a ativação da PKC, seria inibida a fosforilação da subunidade $447^{\text {PHOX }}$ e ativação do complexo NADPH oxidase. É importante ressaltar que deve haver grande participação da beta oxidação como fonte geradora de radicais superóxido em 2,8 mM glicose, como já demonstrado nas ilhotas pancreáticas, visto que a inibição da expressão do receptor não produz completa redução do conteúdo de superóxido mediado pelo palmitato.

Já em 16,7 mM glicose, a inibição da expressão do GPR40 não produziu redução estatisticamente diferente no conteúdo de radicais superóxido estimulado pelo palmitato (Figura 21B). Isso pode advir do percentual de inibição da expressão proteica do receptor, que foi de $54 \%$, e da redução observada no conteúdo da Cu/Zn-SOD apresentado pelas células com reduzida expressão de GPR40 (Figura 20B). Já foi descrito o aumento da atividade dessa enzima citossólica antioxidante em ilhotas pancreáticas submetidas a altas concentrações de glicose (OLIVEIRA; CURI; CARPINELLI, 1999). Logo, em 16,7 mM de glicose, quando sua atividade estaria aumentada, a redução do seu conteúdo proteico seria um fator crítico na dismutação do superóxido a peróxido de hidrogênio, não sendo verificada inibição proeminente no conteúdo final de superóxido. Porém, verificamos também que a condição submetida à inibição do receptor e estimulada com palmitato (16,7 Palm AS) não apresenta conteúdo de superóxido estatisticamente diferente das condições na ausência do palmitato (16,7 C e 16,7 AS) (Figura 21B), o que destaca que o estímulo do palmitato como fonte geradora do radical superóxido seria reduzido. 
A
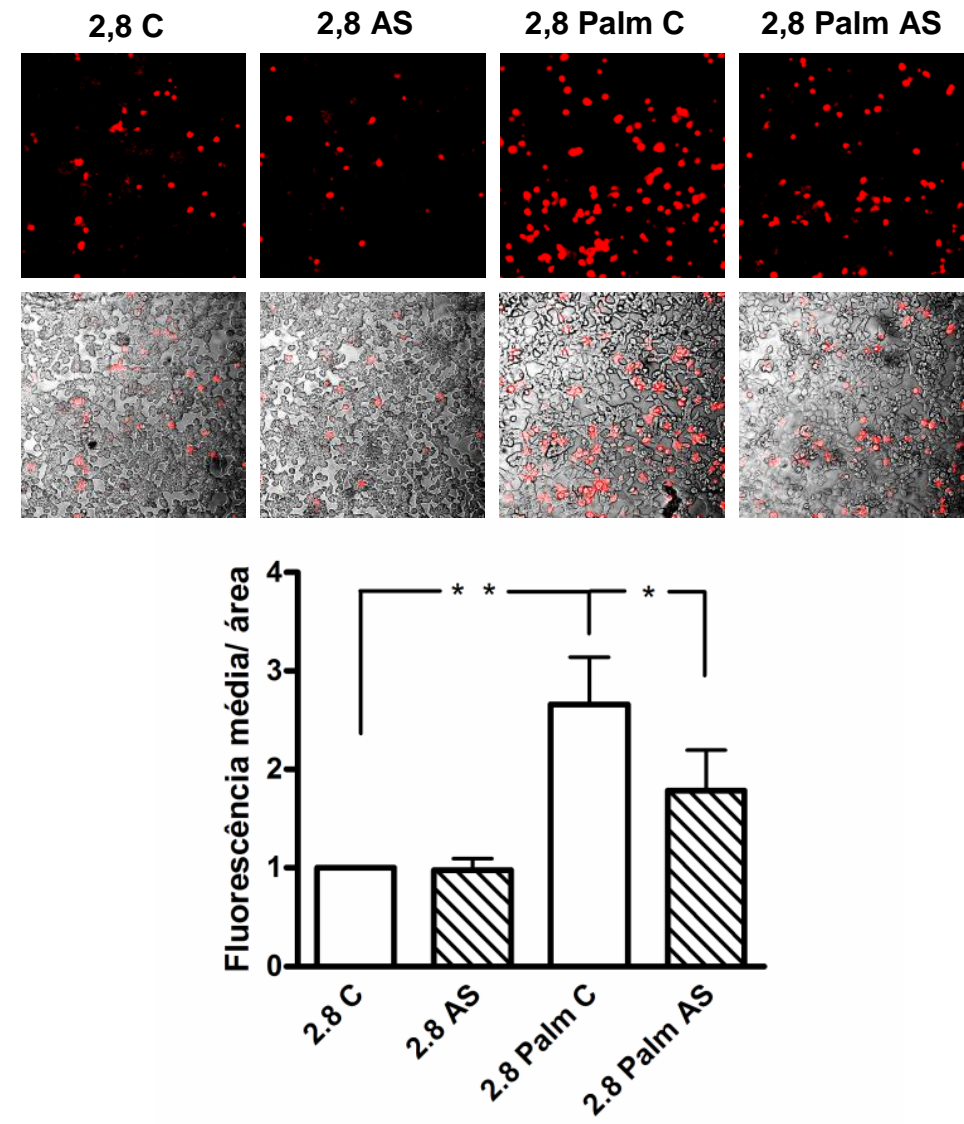

B

16,7 C 16,7 AS
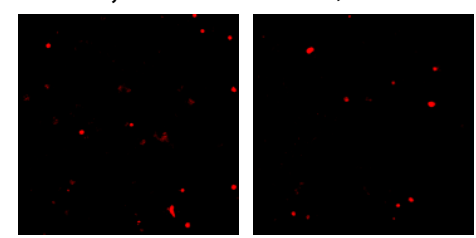

16,7 Palm C

16,7 Palm AS
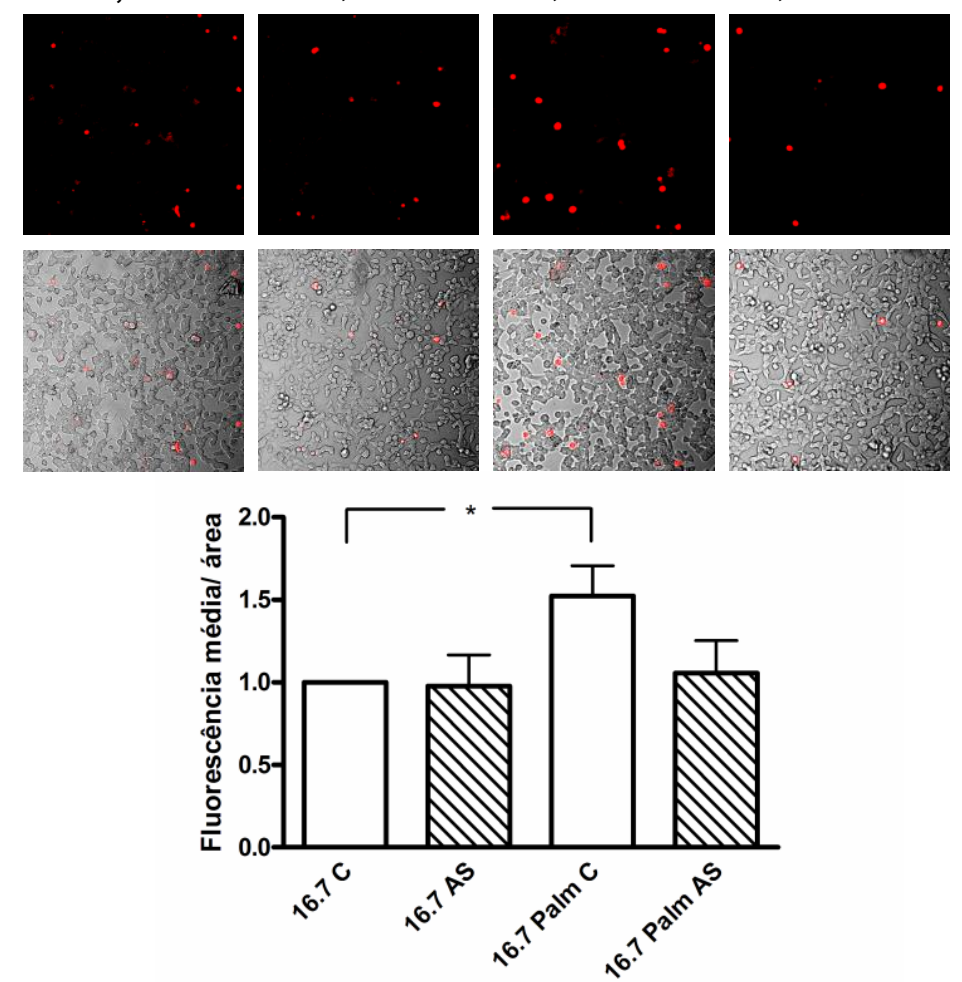

Figura 21 - Conteúdo de superóxido induzido pelo palmitato em 2,8 (A) e 16,7 mM (B) glicose após inibição da expressão do GPR40. A. A inibição da expressão do GPR40 produziu redução no conteúdo de superóxido em 2,8 mM glicose na presença do ácido palmítico. B. Em 16,7 $\mathrm{mM}$ glicose, a inibição do receptor não produziu diferença estatística no conteúdo de superóxido. Nos planos superiores das figuras são demonstradas as imagens de fluorescência e logo abaixo as respectivas imagens de microscopia de luz sobrepostas. C: RNAi controle; AS: RNAi contra o GPR40. (n=7). *P<0,05, **P<0,01. 
É importante ressaltar também a hipótese de que a redução da expressão da SOD-1 observada após inibição do receptor poderia estar associada à manutenção da produção de superóxido celular dentro de limites desejáveis à função celular. Isso, pois, ao observarmos que o GPR40 auxiliaria tal produção, a inibição do receptor causaria efeito reverso, o que poderia ser contra regulado pela redução da expressão dessa enzima antioxidante. Além disso, já foi observado em células endoteliais, o aumento da atividade e expressão da SOD em resposta ao aumento na geração de EROs (CERIELLO et al., 1996). Logo, é conhecida a importância das EROs como reguladoras da atividade e da expressão das enzimas antioxidantes para a manutenção do balanço redox celular.

\subsubsection{Avaliação da secreção de insulina em linhagem INS-1E após inibição da expressão do GPR40}

Observamos que a inibição da expressão do GPR40 reduziu em $41 \%$ a secreção de insulina induzida pelo palmitato em $16,7 \mathrm{mM}$ glicose, após incubação de $1 \mathrm{~h}$. A secreção de insulina induzida por $16,7 \mathrm{mM}$ glicose não foi alterada pela inibição da expressão do receptor (Figura 22). Tais resultados estão de acordo com os estudos desenvolvidos por Latour et al. (2007), onde a resposta insulínica à administração intravenosa de lipídeos foi reduzida em $50 \%$ em camundongos $\mathrm{KO}$ para o receptor, bem como pela observação de que a inibição da expressão do GPR40 reduziu o estímulo do palmitato à secreção de insulina e ao aumento intracelular de cálcio em $25 \mathrm{mM}$ glicose em linhagem INS-1E. Tal evidência também foi observada quando da inibição da proteína Gaq (YM-254890) na mesma linhagem celular (SHAPIRO et al., 2005). Os efeitos de potencialização da secreção de insulina induzida por outros ácidos graxos, como o linoleico, $\gamma$-linolênico e oleico, também foram reduzidos pela inibição da expressão do GPR40 (FUJIWARA; MAEKAWA; YADA, 2005; ITOH et al., 2003; SALEHI et al., 2005).

O palmitato induziu a potencialização da secreção de insulina mesmo em concentrações de baixa glicose $(2,8 \mathrm{mM})$, o que não foi alterado pela inibição da expressão do GPR40 (Figura 22). Tal potencialização da secreção de insulina não é observada em ilhotas pancreáticas (Figura 11), porém o mais proeminente aumento da secreção de insulina ocorre somente em 16,7 mM glicose na linhagem celular, assim como observado nas ilhotas pancreáticas. A diferença se deve provavelmente ao limiar de abertura dos CCDV, que pode variar entre as ilhotas pancreáticas e a INS-1E, porém em ambas as células tal abertura é plenamente alcançada em concentrações elevadas de glicose. O fato da inibição da expressão 
do receptor reduzir a secreção insulínica apenas em alta glicose é comprovado em estudo que demonstra a ação do GPR40 aumentando o influxo de cálcio intracelular apenas em concentrações elevadas de glicose. Nesse mesmo estudo foi observado que o aumento intracelular de cálcio induzido pelo GPR40 é também dependente do cálcio extracelular em linhagem INS-1E (SHAPIRO et al., 2005). Para tanto, seria necessária a pré-ativação dos CCDV pela alta glicose, para que a sinalização intracelular mediada pelo receptor induza um maior influxo desse íon.

Mesmo com o maior conteúdo de superóxido em baixa glicose em relação à alta glicose na presença do ácido palmítico, a magnitude de indução de secreção de insulina é sempre maior em alta glicose, tanto em ilhotas pancreáticas quanto na linhagem (Figuras 11 e 22). Isso é resultado da grande produção mitocondrial em baixa glicose e, provavelmente, da maior dismutação a peróxido de hidrogênio em alta glicose por ação da SOD. Portanto, haveria uma maior produção local mitocondrial de superóxido em baixa glicose, a qual estaria submetida à ação das intensas defesas antioxidantes mitocondriais. Além disso, o superóxido presente no citossol parece ser um elemento contribuinte de sinalização a outros processos que envolveriam a maquinaria exocitótica celular, como também o influxo de cálcio induzindo a secreção insulínica. Também, o superóxido induzido pelos AGLs poderia oxidar o CCDV pré-ativado pelas altas concentrações de glicose, induzindo o maior influxo de cálcio, como já verificado em cardiomiócitos (ZENG et al., 2008).

Foi demostrado que o palmitato eleva a exocitose dos grânulos de insulina e aumenta o tamanho do pool de grânulos prontos para serem secretados, e que tais efeitos do ácido graxo não são mimetizados pela administração de palmitoil-CoA intracelularmente (OLOFSSON et al., 2004b), o que vem a reforçar a importância da ativação do GPR40 como fenômeno contribuinte ao evento secretório induzido por ácidos graxos de cadeia longa. 


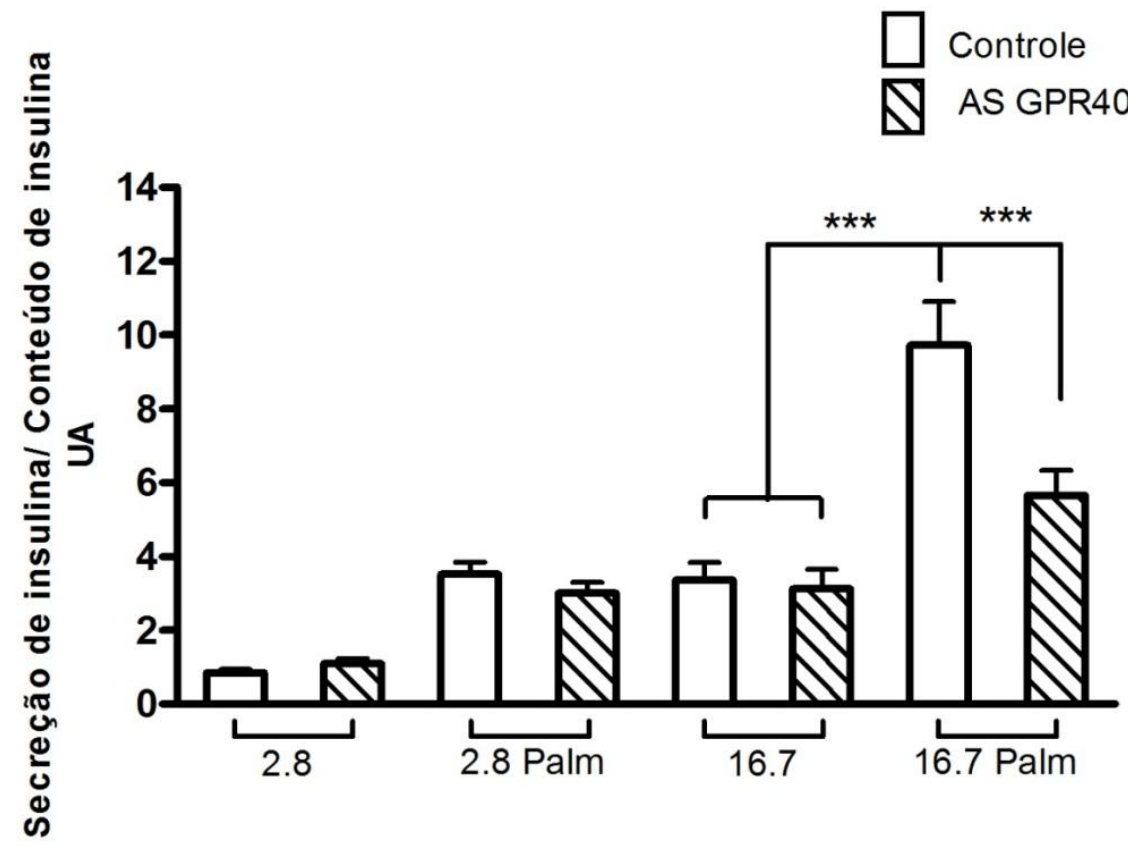

Figura 22 - Secreção de insulina após inibição da expressão do GPR40 e sob 1h de incubação em 2,8 e 16,7 mM glicose na presença de palmitato. As células foram pré-incubadas durante 2 horas em meio RPMI sem glicose, incubadas durante 30min em Krebs-Henseleit sem glicose e após, incubadas em 2,8 ou 16,7 $\mathrm{mM}$ glicose, na presença ou ausência de $1 \mathrm{mM}$ palmitato $(\mathrm{Palm})$ durante 1 hora $(\mathrm{n}=8)$. A secreção de insulina foi normalizada pelo conteúdo de insulina e expressa em relação ao controle (2,8 mM glicose). Os resultados são expressos em média \pm EP da secreção de insulina dividido pelo conteúdo de insulina em relação à condição controle $2,8 \mathrm{mM}$ glicose. *** $\mathrm{P}<0,001$ em relação às condições indicadas. UA, representa a unidade arbitrária de secreção de insulina em comparação a $2,8 \mathrm{mM}$ glicose. 


\subsubsection{Avaliação da secreção de insulina em linhagem INS-1E com o agonista do GPR40.}

O GW9508 é um agonista sintético do GPR40 e do GPR120, sendo cerca de 100 vezes mais seletivo ao primeiro em relação ao segundo (BRISCOE et al., 2006; GARRIDO et al., 2006). Já foi demonstrado que algumas linhagens de células beta, dentre elas a INS-1, expressam o RNAm do GPR120, um receptor também ligado à proteína Gaq (MORGAN e DHAYAL, 2009). Porém, acredita-se que a função do GPR120 na secreção de insulina pelas células beta não seja relevante, tendo efeito importante no intestino, onde comprovadamente modula a secreção de incretinas (HIRASAWA et al., 2005; MOORE et al., 2009), e assim, indiretamente atue estimulando a secreção de insulina. Além disso, a incubação com o antagonista do receptor GPR40 (GW1100) inibiu de maneira dose-depende as elevações de cálcio induzidas pelo GW9508 e pelo ácido linoleico em células beta. Há que se destacar que o GW1100 não apresenta efeito na estimulação intracelular de cálcio induzida pela ativação do GPR120, mostrando a sua especificidade (BRISCOE et al., 2006).

A molécula do GW9508, abaixo representada (Figura 23), foi desenvolvida a partir de várias modificações bioquímicas da molécula do ácido linoleico (GARRIDO et al., 2006; TIKHONOVA et al., 2007), um dos ácidos graxos com maior potencial de ativação do GPR40 humano (ver Tabela 1).

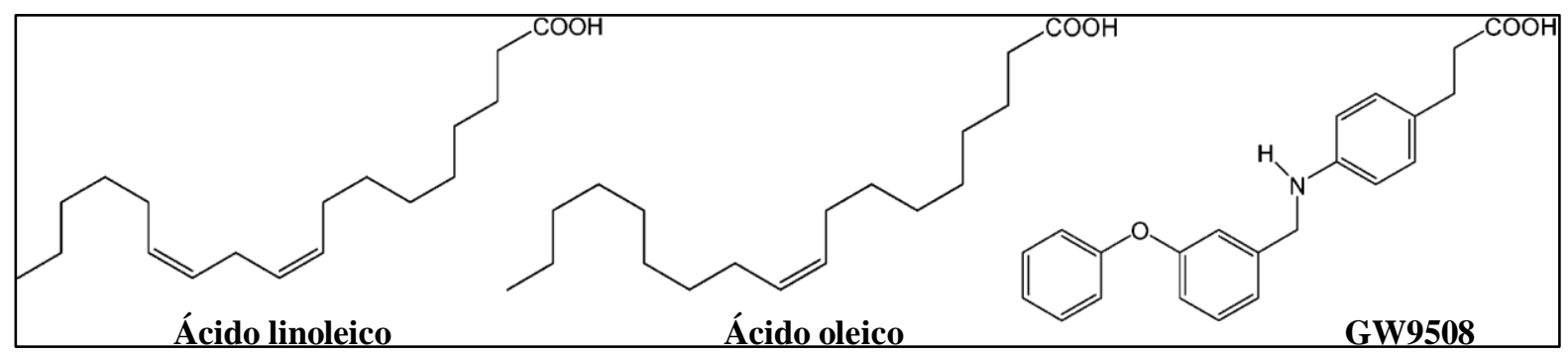

Figura 23 - Fórmula química do ácido linoleico, ácido oleico e do agonista sintético do GPR40 (GW9508). O agonista foi obtido a partir de modificações bioquímicas da molécula do ácido linoleico, apresentando similaridades com o ácido oleico, ambos ácidos graxos com alto potencial de ativação do GPR40.

FONTE: Modificado de Tikhonova et al. (2007). 
Observamos que a incubação com o agonista do receptor (GW9508 a $20 \mu \mathrm{M}$ ) potencializa a secreção de insulina em 38\% em 2,8 mM glicose (Figura 24A) e em 57\% em 16,7 mM (Figura 24B) na linhagem INS-1E. Logo, a habilidade do agonista em induzir a secreção de insulina é dependente da concentração de glicose, sendo o efeito mais proeminentemente observado em alta glicose. Já foi verificado que o GW9508 potencializa a secreção de insulina estimulada pela glicose de maneira dose dependente em linhagem MIN6, e que é aumentado o seu potencial de ativação segundo o aumento da concentração de glicose (BRISCOE et al., 2006). Além disso, tal agonista aumentou o conteúdo intracelular de cálcio em células HEK293 (derivadas de rim embrionário humano) nas quais foi induzida a expressão de GPR40 (BRISCOE et al., 2006). Isso demonstra a ativação de vias intracelulares semelhantes às induzidas pela ativação do receptor.

Tanto em 2,8 quanto em 16,7 mM glicose foi observada inibição da secreção da insulina estimulada pelo agonista por calphostin C e DPI (Figuras 24A e B). Em 2,8 mM glicose na presença de GW9508, a inibição pelo calphostin C foi de $31 \%$ e a do DPI de 36\%; já em 16,7 mM glicose, a redução pelo inibidor da PKC foi de $45 \%$ e pelo inibidor da NADPH oxidase foi de $44 \%$, demonstrando a participação da PKC e da NADPH oxidase no processo de secreção de insulina estimulado pelo GPR40. Observamos que na mesma concentração de glicose os dois inibidores foram capazes de reduzir em magnitude semelhante a secreção de insulina, o que demonstra a inibição de uma via de sinalização comum. Logo, a via de sinalização induzida pelo receptor é capaz de ativar a PKC, a qual ao fosforilar a subunidade $\mathrm{p} 47^{\text {PHOX }}$, ativaria o complexo NADPH oxidase, amplificando a secreção de insulina. Tal efeito é semelhante ao observado pela incubação de ilhotas pancreáticas ou INS-1E com o palmitato, o que vem reforçar que a ativação do GPR40 e de sua via de sinalização intracelular provavelmente fazem parte dos mecanismos de ação induzidos por esse ácido graxo nas células beta pancreáticas.

Ao avaliarmos a secreção de insulina na presença do agonista sintético e do palmitato, observamos que o estímulo secretório induzido pelo ácido palmítico ocorre em magnitude muito maior do que o induzido pelo GW9508 (Figura 24C), o que pode decorrer das concentrações utilizadas de cada um dos reagentes e de seus diferentes potenciais de ligação à albumina. 
A

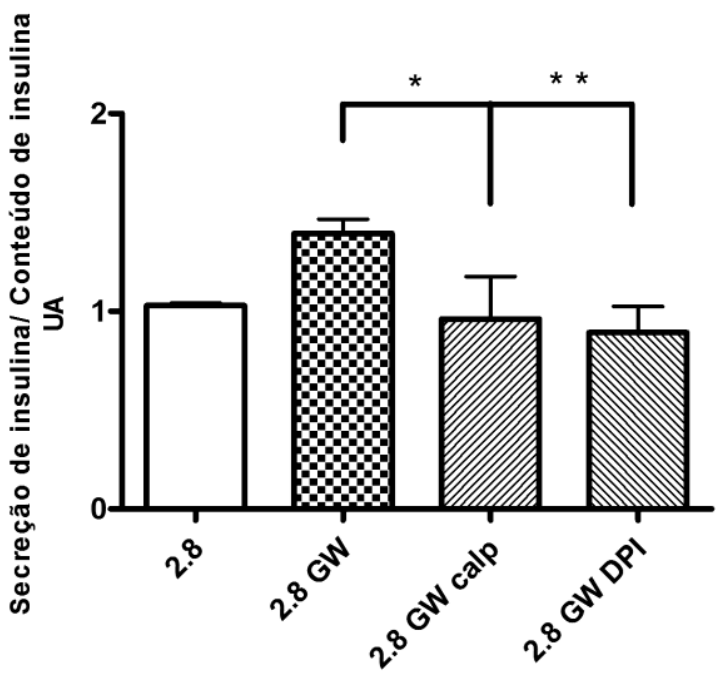

C

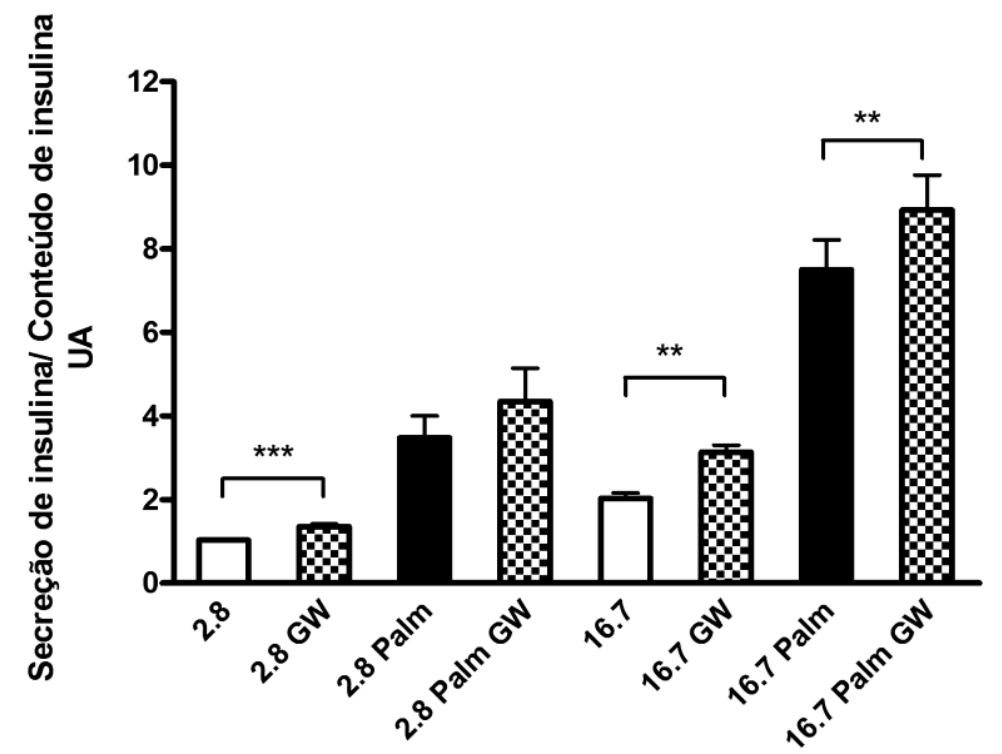

Figura 24 - Secreção de insulina após 1h de incubação em 2,8 e 16,7 mM glicose na presença de GW9508, palmitato e calphostin C e DPI. Secreção de insulina em 2,8 mM (A) ou 16,7mM glicose (B) na presença do agonista do GPR40 (20 $\mu \mathrm{M}$ GW9508), $1 \mu \mathrm{M}$ calphostin C ou 50 nM DPI. D. Secreção de insulina na presença de 2,8 ou 16,7 mM glicose, sob a adição de $20 \mu \mathrm{M}$ GW9508, 0,5 $\mu \mathrm{M}$ calphostin C ou 50 nM DPI. Os resultados são expressos em média \pm EP da secreção de insulina dividido pelo conteúdo de insulina em relação à condição controle $2,8 \mathrm{mM}$ glicose. $* \mathrm{P}<0,1$, $* * * \mathrm{P}<0,01, * * * \mathrm{P}<0,001$ em relação às condições indicadas ( $\mathrm{n} \geq 6$ experimentos independentes). 
Além disso, há que ser lembrado que os ácidos graxos são capazes de ativar múltiplas vias de estimulação da secreção de insulina, bem como a indução de LC-CoA (CORKEY et al., 2000; PRENTKI e CORKEY, 1996), a acilação de proteínas (CORKEY et al., 2000), a ativação de CCVD em alta glicose (OLOFSSON et al., 2004b; WARNOTTE et al., 1994), a ativação de PKC (GRACIANO et al.; HABER et al., 2003a), a exocitose dos grânulos insulínicos (OLOFSSON et al., 2004b), do que advém também a diferença no potencial de amplificação da secreção de insulina do palmitato em relação ao GW9508.

Entretanto, observamos em alta glicose na presença do palmitato um pequeno efeito aditivo na secreção de insulina (19\%) em incubação com o agonista sintético (Figura 24 C), o que poderia sugerir a ativação por diferentes sítios do GPR40 pelo GW9508 e pelo palmitato. Porém, como tal acréscimo é pequeno, dada a magnitude do aumento de secreção induzido pelo palmitato em alta glicose, provavelmente ambos os agonistas, o palmitato e o GW9508, utilizariam mecanismos de ação comuns para a potencialização da secreção de insulina. Todavia, já foi verificado que a adição do GW9508 em concentrações crescentes do ácido linoleico produz um deslocamento da curva dose-resposta de insulina para a esquerda (de 40 para $20 \mu \mathrm{M}$ ácido linoleico) e um leve aumento da amplitude da curva, sugerindo que o ácido linoleico e o GW9508 teriam efeitos aditivos, além de efeitos sinérgicos, em suas ações (BRISCOE et al., 2006). Um exemplo da semelhança de ação intracelular entre o palmitato e o agonista é que o GW9508 não é capaz de estimular a secreção de insulina na presença do diazóxido, o qual promove a abertura dos $\mathrm{K}_{\mathrm{ATP}}$. De maneira análoga, o palmitato requer a despolarização da membrana celular, por meio do fechamento dos $\mathrm{K}_{\mathrm{ATP}}$, e a abertura dos CCDV para que ocorra seu efeito potencializador da secreção insulínica (SHAPIRO et al., 2005). 


\section{CONCLUSÕES}

O palmitato apresenta múltiplas ações nas células beta pancreáticas e, a partir do atual estudo, evidenciamos a sua participação na ativação de uma via não clássica moduladora da secreção de insulina nas ilhotas pancreáticas e células beta. Logo, ativando o complexo NADPH oxidase, o palmitato induz a secreção de insulina e a produção de superóxido agudamente. Tal efeito está implicado na ação fisiológica do ácido graxo, mas também pode, a longo prazo, participar dos mecanismos lipotóxicos nas células beta.

Além disso, demonstramos a ação desse ácido graxo como um potente agonista de GPR40, onde a ativação da sua cascata de sinalização intracelular muito contribui à secreção de insulina in vitro, como também já demonstrada em experimentos in vivo. Destacamos também a participação da via de sinalização induzida pelo GPR40 na ativação do complexo NADPH oxidase. Concomitantemente, a produção de derivados lipídicos do ácido graxo, bem como o DAG, o $\mathrm{IP}_{3}$ e as LC-CoAs (Figura 25), também apresentam mecanismos de sinalização essenciais da modulação do processo secretório, dentre eles, contribuindo para a ativação de $\mathrm{PKC}$, a acilação de proteínas, a mudança da atividade de canais $\mathrm{K}_{\mathrm{ATP}}$ e CCDV.

A produção intracelular de superóxido induzida pelo palmitato em ilhotas pancreáticas e INS-1E mostrou-se dependente da ativação da PKC, do complexo NADPH oxidase, do GPR40 e da beta-oxidação. Nesse contexto, a curta exposição ao ácido palmítico produziu o estímulo à expressão gênica dos componentes da NADPH oxidase e também à expressão proteica da subunidade $\mathrm{p} 47^{\mathrm{PHOX}}$. Os atuais resultados evidenciam as variações do conteúdo intracelular de superóxido oriundos da mitocôndria ou citossol como ocorrências fisiológicas nas células beta, atuando na sinalização da secreção insulínica. Porém, o descontrole entre a produção dessas espécies reativas e os mecanismos antioxidantes pode acarretar a disfunção das células beta, havendo a perda do balanço redox celular. Logo, o aumento da atividade da NADPH oxidase contribuindo ao incremento de superóxido, quando dentro dos limites celulares para a manutenção do balanço redox, pode agir como importante sinalizador do fenômeno secretório induzido pelo palmitato. 


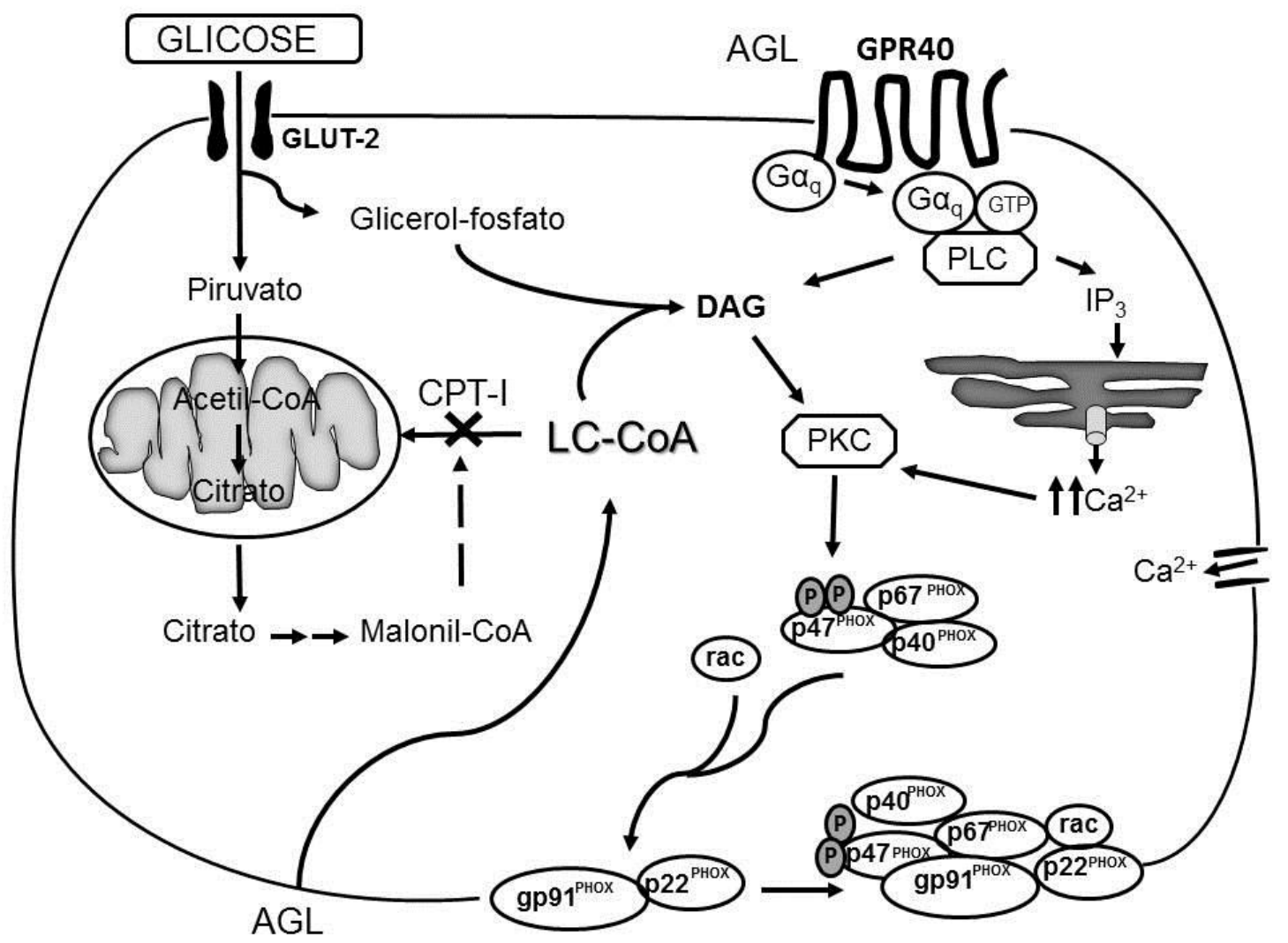

Figura 25 - Mecanismo proposto para modulação da NADPH oxidase em ilhotas pancreáticas. Os AGLs amplificam a secreção de insulina induzida por alta glicose através da formação da malonil-CoA que inibe a CPT-I, levando ao acúmulo de LC-CoA no citossol. O influxo de AGLs nas células beta produz o aumento da concentração de LC-CoA, elevando assim, o conteúdo de DAG pela reação com o glicerol-fosfato. A ativação do GPR40 pelos AGLs de cadeia longa induz a ativação da via de sinalização da Gaq-PLC, produzindo a saída de cálcio do retículo endoplasmático e a produção de DAG. O aumento de DAG e cálcio estão envolvidos na ativação da PKC, que fosforila as subunidades da NADPH oxidase, induzindo a translocação das subunidades citoplasmáticas para o complexo da membrana. Dessa forma, o complexo enzimático tona-se ativo e catalisa a produção de superóxido. LC-CoA: coenzima A de cadeia longa; $\mathrm{IP}_{3}$ : inositol-trifosfato; DAG: diacilglicerol; GTP: guanosina trifosfato.

FONTE: Modificado de Graciano et al. (2010). 


\section{REFERÊNCIAS*}

ADAM-VIZI, V.; CHINOPOULOS, C. Bioenergetics and the formation of mitochondrial reactive oxygen species. Trends Pharmacol. Sci., v. 27, n. 12, p. 639-645, 2006.

ALCAZAR, O. et al. Stimulation of islet protein kinase $\mathrm{C}$ translocation by palmitate requires metabolism of the fatty acid. Diabetes, v. 46, n. 7, p. 1153-1158, 1997.

ALQUIER, T. et al. Deletion of GPR40 Impairs Glucose-induced Insulin Secretion in Vivo in Mice Without Affecting Intracellular Fuel Metabolism in Islets. Diabetes, v. 58, n. 11, p. 2607-2615, 2009.

ANDREWS, P. C.; BABIOR, B. M. Phosphorylation of cytosolic proteins by resting and activated human neutrophils. Blood, v. 64, n. 4, p. 883-890, 1984.

ANDREYEV, A. Y.; KUSHNAREVA, Y. E.; STARKOV, A. A. Mitochondrial metabolism of reactive oxygen species. Biochemistry (Mosc). v. 70, n. 2, p. 200-214, 2005.

ANRATHER, J.; RACCHUMI, G.; IADECOLA, C. NF-kappaB regulates phagocytic NADPH oxidase by inducing the expression of gp91phox. J. Biol. Chem., v. 281, n. 9, p. 5657-5667, 2006.

ASFARI, M. et al. Establishment of 2-mercaptoethanol-dependent differentiated insulinsecreting cell lines. Endocrinology, v. 130, n. 1, p. 167-178, 1992.

BABIOR, B. M. The leukocyte NADPH oxidase. Israel Medical Association Journal: Imaj, v. 4, n. 11, p. 1023-1024, 2002.

BARTOOV-SHIFMAN, R. et al. Regulation of the gene encoding GPR40, a fatty acid receptor expressed selectively in pancreatic beta cells. J. Biol. Chem., v. 282, n. 32, p. 2356123571, 2007.

BAULCOMBE, D. RNA silencing in plants. Nature, v. 431, n. 7006, p. 356-363, 2004.

BECKMAN, J. S. et al. Superoxide dismutase and catalase conjugated to polyethylene glycol increases endothelial enzyme activity and oxidant resistance. J Biol Chem, v. 263, n. 14, p. 6884-6892, 1988a. 
BECKMAN, J. S. et al. Superoxide dismutase and catalase conjugated to polyethylene glycol increases endothelial enzyme activity and oxidant resistance. J. Biol. Chem., v. 263, n. 14, p. 6884-6892, 1988b.

BEDARD, K.; KRAUSE, K. H. The NOX family of ROS-generating NADPH oxidases: physiology and pathophysiology. Physiol. Rev., v. 87, n. 1, p. 245-313, 2007.

BEDARD, K.; LARDY, B.; KRAUSE, K. H. NOX family NADPH oxidases: not just in mammals. Biochimie, v. 89, n. 9, p. 1107-1112, 2007.

BEST, L.; DUNLOP, M.; MALAISSE, W. J. Phospholipid metabolism in pancreatic islets. Experientia, v. 40, n. 10, p. 1085-1091, 1984.

BEY, E. A. et al. Protein kinase $\mathrm{C}$ delta is required for $\mathrm{p} 47$ phox phosphorylation and translocation in activated human monocytes. J. Immunol., v. 173, n. 9, p. 5730-5738, 2004.

BINDOKAS, V. P. et al. Visualizing superoxide production in normal and diabetic rat islets of Langerhans. J. Biol. Chem., v. 278, n. 11, p. 9796-9801, 2003.

BORNANCIN, F.; PARKER, P. J. Phosphorylation of threonine 638 critically controls the dephosphorylation and inactivation of protein kinase Calpha. Curr. Biol., v. 6, n. 9, p. 11141123, 1996.

BORREGAARD, N. et al. Subcellular localization of the b-cytochrome component of the human neutrophil microbicidal oxidase: translocation during activation. J. Cell Biol., v. 97, n. 1, p. 52-61, 1983.

BRISCOE, C. P. et al. Pharmacological regulation of insulin secretion in MIN6 cells through the fatty acid receptor GPR40: identification of agonist and antagonist small molecules. Br $\mathbf{J}$ Pharmacol, v. 148, n. 5, p. 619-628, 2006.

BRISCOE, C. P. et al. The orphan G protein-coupled receptor GPR40 is activated by medium and long chain fatty acids. J. Biol. Chem., v. 278, n. 13, p. 11303-11311, 2003.

BROWNLEE, M. The pathobiology of diabetic complications: a unifying mechanism. Diabetes, v. 54, n. 6, p. 1615-1625, 2005. 
CARPINELLI, A. R. et al. Insulin secretion induced by palmitate--a process fully dependent on glucose concentration. Diabetes Metab., v. 28, n. 6, pt 2, p. 3S37-44; discussion 33S108$112,2002$.

CARTONI, C. et al. Taste preference for fatty acids is mediated by GPR40 and GPR120. J. Neurosci., v. 30, n. 25, p. 8376-8382, 2010.

CEOLOTTO, G. et al. Insulin generates free radicals by an $\mathrm{NAD}(\mathrm{P}) \mathrm{H}$, phosphatidylinositol 3'-kinase-dependent mechanism in human skin fibroblasts ex vivo. Diabetes, v. 53, n. 5, p. 1344-1351, 2004.

CERIELLO, A. et al. High glucose induces antioxidant enzymes in human endothelial cells in culture. Evidence linking hyperglycemia and oxidative stress. Diabetes, v. 45, n. 4, p. 471477, 1996.

CERIELLO, A.; MOTZ, E. Is oxidative stress the pathogenic mechanism underlying insulin resistance, diabetes, and cardiovascular disease? The common soil hypothesis revisited. Arterioscler. Thromb. Vasc. Biol., v. 24, n. 5, p. 816-823, 2004.

CHEN, S. et al. More direct evidence for a malonyl-CoA-carnitine palmitoyltransferase I interaction as a key event in pancreatic beta-cell signaling. Diabetes, v. 43, n. 7, p. 878-883, 1994.

CNOP, M. et al. Inverse relationship between cytotoxicity of free fatty acids in pancreatic islet cells and cellular triglyceride accumulation. Diabetes, v. 50, n. 8, p. 1771-1777, 2001.

CORKEY, B. E. et al. The role of long-chain fatty acyl-CoA esters in beta-cell signal transduction. J. Nutr., v. 130, n. 2S, p. 299S-304S, 2000.

COZIER, G. E. et al. The phox homology (PX) domain-dependent, 3-phosphoinositidemediated association of sorting nexin-1 with an early sorting endosomal compartment is required for its ability to regulate epidermal growth factor receptor degradation. J. Biol. Chem., v. 277, n. 50, p. 48730-48736, 2002.

DEENEY, J. T. et al. Reversible Ca2+-dependent translocation of protein kinase $\mathrm{C}$ and glucose-induced insulin release. J. Biol. Chem., v. 271, n. 30, p. 18154-18160, 1996.

DEENEY, J. T. et al. Acyl-CoA esters modulate intracellular Ca2+ handling by permeabilized clonal pancreatic beta-cells. J. Biol. Chem., v. 267, n. 28, p. 19840-19845, 1992. 
DEL GUERRA, S. et al. G-protein-coupled receptor 40 (GPR40) expression and its regulation in human pancreatic islets: The role of type 2 diabetes and fatty acids. Nutr. Metab. Cardiovasc. Dis., v. 20, n. 1, p. 22-25, 2010.

DELEO, F. R. et al. Processing and maturation of flavocytochrome b558 include incorporation of heme as a prerequisite for heterodimer assembly. J. Biol. Chem., v. 275, n. 18 , p. 13986-13993, 2000.

DINAUER, M. C.; ORKIN, S. H. Chronic granulomatous disease. Annu. Rev. Med., v. 43, n., p. 117-124, 1992.

DOSHI, L. S. et al. Acute administration of GPR40 receptor agonist potentiates glucosestimulated insulin secretion in vivo in the rat. Metabolism., v. 58, n. 3, p. 333-343, 2009.

EBELT, H. et al. Influence of melatonin on free radical-induced changes in rat pancreatic beta-cells in vitro. J. Pineal Res., v. 28, n. 2, p. 65-72, 2000.

EDFALK, S.; STENEBERG, P.; EDLUND, H. Gpr40 is expressed in enteroendocrine cells and mediates free fatty acid stimulation of incretin secretion. Diabetes, v. 57, n. 9, p. 22802287, 2008.

EITEL, K. et al. Different role of saturated and unsaturated fatty acids in beta-cell apoptosis. Biochem. Biophys. Res. Commun., v. 299, n. 5, p. 853-856, 2002.

EIZIRIK, D. L.; MANDRUP-POULSEN, T. A choice of death--the signal-transduction of immune-mediated beta-cell apoptosis. Diabetologia, v. 44, n. 12, p. 2115-2133, 2001.

FENG, D. D. et al. Reduction in voltage-gated $\mathrm{K}+$ currents in primary cultured rat pancreatic beta-cells by linoleic acids. Endocrinology, v. 147, n. 2, p. 674-682, 2006.

FISHER, A. B. Redox signaling across cell membranes. Antioxid. Redox Signal, v. 11, n. 6, p. 1349-1356, 2009.

FLODGREN, E. et al. GPR40 is expressed in glucagon producing cells and affects glucagon secretion. Biochem. Biophys. Res. Commun., v. 354, n. 1, p. 240-245, 2007. 
FONTAYNE, A. et al. Phosphorylation of p47phox sites by PKC alpha, beta II, delta, and zeta: effect on binding to p22phox and on NADPH oxidase activation. Biochemistry (Mosc). v. 41, n. 24, p. 7743-7750, 2002.

FUCHS, A. et al. The 40-kDa component of the phagocyte NADPH oxidase (p40phox) is phosphorylated during activation in differentiated HL60 cells. Eur. J. Biochem., v. 249, n. 2, p. 531-539, 1997.

FUJIWARA, K.; MAEKAWA, F.; YADA, T. Oleic acid interacts with GPR40 to induce $\mathrm{Ca} 2+$ signaling in rat islet beta-cells: mediation by PLC and L-type Ca2+ channel and link to insulin release. Am J Physiol Endocrinol Metab, v. 289, n. 4, p. E670-677, 2005.

FURUKAWA, S. et al. Increased oxidative stress in obesity and its impact on metabolic syndrome. J. Clin. Invest., v. 114, n. 12, p. 1752-1761, 2004.

GAGERMAN, E.; SEHLIN, J.; TALJEDAL, I. B. Effects of acetylcholine on ion fluxes and chlorotetracycline fluorescence in pancreatic islets. J Physiol, v. 300, p. 505-513, 1980.

GANESAN, S. et al. Immunocytochemical localization of alpha-protein kinase $\mathrm{C}$ in rat pancreatic beta-cells during glucose-induced insulin secretion. J. Cell Biol., v. 119, n. 2, p. 313-324, 1992.

GARRIDO, D. M. et al. Synthesis and activity of small molecule GPR40 agonists. Bioorg. Med. Chem. Lett., v. 16, n. 7, p. 1840-1845, 2006.

GAUSS, K. A. et al. Role of NF-kappaB in transcriptional regulation of the phagocyte NADPH oxidase by tumor necrosis factor-alpha. J. Leukoc. Biol., v. 82, n. 3, p. 729-741, 2007.

GEMBAL, M.; GILON, P.; HENQUIN, J. C. Evidence that glucose can control insulin release independently from its action on ATP-sensitive $\mathrm{K}+$ channels in mouse B cells. J. Clin. Invest., v. 89, n. 4, p. 1288-1295, 1992.

GILON, P.; HENQUIN, J. C. Mechanisms and physiological significance of the cholinergic control of pancreatic beta-cell function. Endocr. Rev., v. 22, n. 5, p. 565-604, 2001.

GILON, P.; NENQUIN, M.; HENQUIN, J. C. Muscarinic stimulation exerts both stimulatory and inhibitory effects on the concentration of cytoplasmic $\mathrm{Ca} 2+$ in the electrically excitable pancreatic B-cell. Biochem. J., v. 311 ( Pt 1), p. 259-267, 1995. 
GOLDSTEIN, B. J.; MAHADEV, K.; WU, X. Redox paradox: insulin action is facilitated by insulin-stimulated reactive oxygen species with multiple potential signaling targets. Diabetes, v. 54, n. 2, p. 311-321, 2005.

GOLDSTEIN, B. J. et al. Role of insulin-induced reactive oxygen species in the insulin signaling pathway. Antioxidants \& Redox Signaling, v. 7, n. 7-8, p. 1021-1031, 2005.

GRACIANO, M. F. et al. Palmitate activates insulin signaling pathway in pancreatic rat islets. Pancreas, v. 38, n. 5, p. 578-584, 2009.

GRACIANO, M. F. et al. NAD(P)H oxidase participates in the palmitate-induced superoxide production and insulin secretion by rat pancreatic islets. J. Cell. Physiol., 2010. In press.

GRANKVIST, K.; MARKLUND, S. L.; TALJEDAL, I. B. CuZn-superoxide dismutase, Mnsuperoxide dismutase, catalase and glutathione peroxidase in pancreatic islets and other tissues in the mouse. Biochem. J., v. 199, n. 2, p. 393-398, 1981.

GRIENDLING, K. K. et al. Angiotensin II stimulates NADH and NADPH oxidase activity in cultured vascular smooth muscle cells. Circ. Res., v. 74, n. 6, p. 1141-1148, 1994.

GRIENDLING, K. K.; SORESCU, D.; USHIO-FUKAI, M. NAD(P)H oxidase: role in cardiovascular biology and disease. Circ. Res., v. 86, n. 5, p. 494-501, 2000.

GROEMPING, Y. et al. Molecular basis of phosphorylation-induced activation of the NADPH oxidase. Cell, v. 113, n. 3, p. 343-355, 2003.

HABER, E. P. et al. Palmitate modulates the early steps of insulin signalling pathway in pancreatic islets. FEBS Lett., v. 544, n. 1-3, p. 185-188, 2003 a.

HABER, E. P. et al. New insights into fatty acid modulation of pancreatic beta-cell function. Int. Rev. Cytol., v. 248, p. 1-41, 2006.

HABER, E. P. et al. Pleiotropic effects of fatty acids on pancreatic beta-cells. J. Cell. Physiol., v. 194, n. 1, p. 1-12, 2003 b.

HARPER, A. M.; CHAPLIN, M. F.; SEGAL, A. W. Cytochrome b-245 from human neutrophils is a glycoprotein. Biochem. J., v. 227, n. 3, p. 783-788, 1985. 
HAYAKAWA, T. et al. A possible role for protein phosphorylation in the activation of the respiratory burst in human neutrophils. Evidence from studies with cells from patients with chronic granulomatous disease. J. Biol. Chem., v. 261, n. 20, p. 9109-9115, 1986.

HELLEMANS, K. et al. Peroxisome proliferator-activated receptor alpha-retinoid X receptor agonists induce beta-cell protection against palmitate toxicity. Febs J, v. 274, n. 23, p. 60946105, 2007.

HEYWORTH, P. G.; BADWEY, J. A. Continuous phosphorylation of both the 47 and the 49 $\mathrm{kDa}$ proteins occurs during superoxide production by neutrophils. Biochim. Biophys. Acta, v. 1052, n. 2, p. 299-305, 1990.

HIGAI, K. et al. Glycated human serum albumin enhances macrophage inflammatory protein1 beta mRNA expression through protein kinase C-delta and NADPH oxidase in macrophagelike differentiated U937 cells. Biochim. Biophys. Acta, v. 1780, n. 2, p. 307-314, 2008.

HIRABARA, S. M. et al. Time-dependent effects of fatty acids on skeletal muscle metabolism. J. Cell. Physiol., v. 210, n. 1, p. 7-15, 2007.

HIRASAWA, A. et al. Free fatty acids regulate gut incretin glucagon-like peptide-1 secretion through GPR120. Nat. Med., v. 11, n. 1, p. 90-94, 2005.

HU, L. et al. Regulation of lipolytic activity by long-chain acyl-coenzyme $\mathrm{A}$ in islets and adipocytes. Am. J. Physiol. Endocrinol. Metab., v. 289, n. 6, p. E1085-1092, 2005.

HUGHES, S. J. et al. Stimulation of insulin release by vasopressin in the clonal beta-cell line, HIT-T15: the role of protein kinase C. J. Mol. Endocrinol., v. 8, n. 2, p. 145-153, 1992.

IACCIO, A. et al. Protein kinase $\mathrm{C}$-alpha and -delta are required for NADPH oxidase activation in WKYMVm-stimulated IMR90 human fibroblasts. Arch. Biochem. Biophys., v. 459, n. 2, p. 288-294, 2007.

IMOTO, $\mathrm{H}$. et al. Impaired insulin secretion by diphenyleneiodium associated with perturbation of cytosolic Ca2+ dynamics in pancreatic beta-cells. Endocrinology, v. 149, n. 11, p. 5391-5400, 2008.

INOGUCHI, T. et al. High glucose level and free fatty acid stimulate reactive oxygen species production through protein kinase $\mathrm{C}$--dependent activation of $\mathrm{NAD}(\mathrm{P}) \mathrm{H}$ oxidase in cultured vascular cells. Diabetes, v. 49, n. 11, p. 1939-1945, 2000. 
ITOH, Y. et al. Free fatty acids regulate insulin secretion from pancreatic beta cells through GPR40. Nature, v. 422, n. 6928, p. 173-176, 2003.

IVARSSON, R. et al. Redox control of exocytosis: regulatory role of NADPH, thioredoxin, and glutaredoxin. Diabetes, v. 54, n. 7, p. 2132-2142, 2005.

JANJIC, D. et al. Free radical modulation of insulin release in INS-1 cells exposed to alloxan. Biochem. Pharmacol., v. 57, n. 6, p. 639-648, 1999.

JOHNSON, J. L. et al. Activation of p47(PHOX), a cytosolic subunit of the leukocyte NADPH oxidase. Phosphorylation of ser-359 or ser-370 precedes phosphorylation at other sites and is required for activity. J. Biol. Chem., v. 273, n. 52, p. 35147-35152, 1998.

JONES, P. M.; PERSAUD, S. J.; HOWELL, S. L. Insulin secretion and protein phosphorylation in PKC-depleted islets of Langerhans. Life Sci, v. 50, n. 11, p. 761-767, 1992.

KADRI-HASSANI, N.; LEGER, C. L.; DESCOMPS, B. The fatty acid bimodal action on superoxide anion production by human adherent monocytes under phorbol 12-myristate 13acetate or diacylglycerol activation can be explained by the modulation of protein kinase $\mathrm{C}$ and p47phox translocation. J. Biol. Chem., v. 270, n. 25, p. 15111-15118, 1995.

KERANEN, L. M.; DUTIL, E. M.; NEWTON, A. C. Protein kinase C is regulated in vivo by three functionally distinct phosphorylations. Curr. Biol., v. 5, n. 12, p. 1394-1403, 1995.

KLEINBERG, M. E.; MALECH, H. L.; ROTROSEN, D. The phagocyte 47-kilodalton cytosolic oxidase protein is an early reactant in activation of the respiratory burst. J. Biol. Chem., v. 265, n. 26, p. 15577-15583, 1990.

KNUTSON, K. L.; HOENIG, M. Identification and subcellular characterization of protein kinase-C isoforms in insulinoma beta-cells and whole islets. Endocrinology, v. 135, n. 3, p. 881-886, 1994.

KOGA, H. et al. Tetratricopeptide repeat (TPR) motifs of p67(phox) participate in interaction with the small GTPase Rac and activation of the phagocyte NADPH oxidase. J. Biol. Chem., v. 274, n. 35, p. 25051-25060, 1999. 
KOMATSU, M. et al. Glucose stimulation of insulin release in the absence of extracellular $\mathrm{Ca} 2+$ and in the absence of any increase in intracellular $\mathrm{Ca} 2+$ in rat pancreatic islets. Proc. Natl. Acad. Sci. U. S. A., v. 92, n. 23, p. 10728-10732, 1995.

KOTANI, S. et al. Dietary supplementation of arachidonic and docosahexaenoic acids improves cognitive dysfunction. Neurosci. Res., v. 56, n. 2, p. 159-164, 2006.

KOTARSKY, K. et al. Progress in methodology. Improved reporter gene assays used to identify ligands acting on orphan seven-transmembrane receptors. Pharmacol. Toxicol., v. 93, n. 6, p. 249-258, 2003.

LACY, P. E.; KOSTIANOVSKY, M. Method for the isolation of intact islets of Langerhans from the rat pancreas. Diabetes, v. 16, n. 1, p. 35-39, 1967.

LAMBERTUCCI, R. $\mathrm{H}$. et al. Palmitate increases superoxide production through mitochondrial electron transport chain and NADPH oxidase activity in skeletal muscle cells. J. Cell. Physiol., v. 216, n. 3, p. 796-804, 2008.

LAMBETH, J. D. NOX enzymes and the biology of reactive oxygen. Nat. Rev. Immunol., v. 4, n. 3, p. 181-189, 2004.

LAN, H. et al. Lack of FFAR1/GPR40 does not protect mice from high-fat diet-induced metabolic disease. Diabetes, v. 57, n. 11, p. 2999-3006, 2008.

LARSSON, O. et al. Activation of the ATP-sensitive K+ channel by long chain acyl-CoA. A role in modulation of pancreatic beta-cell glucose sensitivity. J. Biol. Chem., v. 271, n. 18, p. 10623-10626, 1996.

LATOUR, M. G. et al. GPR40 is necessary but not sufficient for fatty acid stimulation of insulin secretion in vivo. Diabetes, v. 56, n. 4, p. 1087-1094, 2007.

LEBRUN, P.; MALAISSE, W. J.; HERCHUELZ, A. Activation, but not inhibition, by glucose of $\mathrm{Ca} 2+-$ dependent $\mathrm{K}+$ permeability in the rat pancreatic B-cell. Biochim. Biophys. Acta, v. 731, n. 2, p. 145-150, 1983.

LEHTIHET, M. et al. Glibenclamide inhibits islet carnitine palmitoyltransferase 1 activity, leading to PKC-dependent insulin exocytosis. Am. J. Physiol. Endocrinol. Metab., v. 285, n. 2, p. E438-446, 2003. 
LELOUP, C. et al. Mitochondrial reactive oxygen species are obligatory signals for glucoseinduced insulin secretion. Diabetes, v. 58, n. 3, p. 673-681, 2009.

LENZEN, S.; DRINKGERN, J.; TIEDGE, M. Low antioxidant enzyme gene expression in pancreatic islets compared with various other mouse tissues. Free Radic. Biol. Med., v. 20, n. 3, p. 463-466, 1996.

LEUNG, K. K.; LEUNG, P. S. Effects of hyperglycemia on angiotensin II receptor type 1 expression and insulin secretion in an INS-1E pancreatic beta-cell line. Jop, v. 9, n. 3, p. 290299, 2008.

LI, L. et al. Endothelin-1 increases vascular superoxide via endothelin(A)-NADPH oxidase pathway in low-renin hypertension. Circulation, v. 107, n. 7, p. 1053-1058, 2003.

LIMA, T. M. et al. Ranking the toxicity of fatty acids on Jurkat and Raji cells by flow cytometric analysis. Toxicol. In Vitro, v. 16, n. 6, p. 741-747, 2002.

LIVAK, K. J.; SCHMITTGEN, T. D. Analysis of relative gene expression data using realtime quantitative PCR and the 2(-Delta Delta C(T)) Method. Methods (Duluth), v. 25, n. 4, p. 402-408, 2001.

MA, D. et al. Expression of free fatty acid receptor GPR40 in the central nervous system of adult monkeys. Neurosci. Res., v. 58, n. 4, p. 394-401, 2007.

MAECHLER, P.; JORNOT, L.; WOLLHEIM, C. B. Hydrogen peroxide alters mitochondrial activation and insulin secretion in pancreatic beta cells. J. Biol. Chem., v. 274, n. 39, p. 27905-27913, 1999.

MAEDLER, K. et al. Distinct effects of saturated and monounsaturated fatty acids on betacell turnover and function. Diabetes, v. 50, n. 1, p. 69-76, 2001.

MAHADEV, K. et al. Hydrogen peroxide generated during cellular insulin stimulation is integral to activation of the distal insulin signaling cascade in 3T3-L1 adipocytes. J. Biol. Chem., v. 276, n. 52, p. 48662-48669, 2001a.

MAHADEV, K. et al. Insulin-stimulated hydrogen peroxide reversibly inhibits proteintyrosine phosphatase $1 \mathrm{~b}$ in vivo and enhances the early insulin action cascade. J. Biol. Chem., v. 276, n. 24, p. 21938-21942, 2001 b. 
MAJUMDAR, S. et al. Protein kinase $\mathrm{C}$ isotypes and signal-transduction in human neutrophils: selective substrate specificity of calcium-dependent beta-PKC and novel calciumindependent nPKC. Biochim. Biophys. Acta, v. 1176, n. 3, p. 276-286, 1993.

MARDEN, C. M. et al. Differentiation-dependent up-regulation of p47(phox) gene transcription is associated with changes in PU.1 phosphorylation and increased binding affinity. Biochem. Biophys. Res. Commun., v. 305, n. 1, p. 193-202, 2003.

MARTINS, E. F. et al. Changes of fatty acid composition in incubated rat pancreatic islets. Diabetes Metab., v. 30, n. 1, p. 21-27, 2004.

MCGAHON, B. M. et al. Age-related changes in oxidative mechanisms and LTP are reversed by dietary manipulation. Neurobiol. Aging, v. 20, n. 6, p. 643-653, 1999.

MERGLEN, A. et al. Glucose sensitivity and metabolism-secretion coupling studied during two-year continuous culture in INS-1E insulinoma cells. Endocrinology, v. 145, n. 2, p. 667678, 2004.

MIKAMI, A. et al. Primary structure and functional expression of the cardiac dihydropyridine-sensitive calcium channel. Nature, v. 340, n. 6230, p. 230-233, 1989.

MOLDOVAN, L. et al. Reactive oxygen species in vascular endothelial cell motility. Roles of NAD(P)H oxidase and Rac1. Cardiovasc. Res., v. 71, n. 2, p. 236-246, 2006.

MOLLER, D. E.; KAUFMAN, K. D. Metabolic syndrome: a clinical and molecular perspective. Annu. Rev. Med., v. 56, n., p. 45-62, 2005.

MOORE, K. et al. Cloning, expression, and pharmacological characterization of the GPR120 free fatty acid receptor from cynomolgus monkey: comparison with human GPR120 splice variants. Comp. Biochem. Physiol. B. Biochem. Mol. Biol., v. 154, n. 4, p. 419-426, 2009.

MORGAN, D. et al. Glucose, palmitate and pro-inflammatory cytokines modulate production and activity of a phagocyte-like NADPH oxidase in rat pancreatic islets and a clonal beta cell line. Diabetologia, v. 50, n. 2, p. 359-369, 2007.

MORGAN, D. et al. Association of NAD(P)H oxidase with glucose-induced insulin secretion by pancreatic beta-cells. Endocrinology, v. 150, n. 5, p. 2197-2201, 2009. 
MORGAN, N. G.; DHAYAL, S. G-protein coupled receptors mediating long chain fatty acid signalling in the pancreatic beta-cell. Biochem. Pharmacol., v. 78, n. 12, p. 1419-1427, 2009.

MULLER, G. et al. Hydrogen peroxide-induced translocation of glycolipid-anchored (c)AMP-hydrolases to lipid droplets mediates inhibition of lipolysis in rat adipocytes. Br. J. Pharmacol., v. 154, n. 4, p. 901-913, 2008.

NAGASUMI, K. et al. Overexpression of GPR40 in pancreatic beta-cells augments glucosestimulated insulin secretion and improves glucose tolerance in normal and diabetic mice.

Diabetes, v. 58, n. 5, p. 1067-1076, 2009.

NAKAYAMA, M. et al. Increased expression of NAD(P)H oxidase in islets of animal models of Type 2 diabetes and its improvement by an AT1 receptor antagonist. Biochem. Biophys. Res. Commun., v. 332, n. 4, p. 927-933, 2005.

NAUSEEF, W. M. Biological roles for the NOX family NADPH oxidases. J. Biol. Chem., v. 283, n. 25, p. 16961-16965, 2008.

NEWTON, A. C. Regulation of the ABC kinases by phosphorylation: protein kinase $\mathrm{C}$ as a paradigm. Biochem. J., v. 370, pt 2, p. 361-371, 2003.

NICOLETTI, I. et al. A rapid and simple method for measuring thymocyte apoptosis by propidium iodide staining and flow cytometry. J. Immunol. Methods, v. 139, n. 2, p. 271279, 1991.

NIXON, J. B.; MCPHAIL, L. C. Protein kinase C (PKC) isoforms translocate to Tritoninsoluble fractions in stimulated human neutrophils: correlation of conventional PKC with activation of NADPH oxidase. J. Immunol., v. 163, n. 8, p. 4574-4582, 1999.

NOGUEIRA, T. C. et al. Short-term modulation of extracellular signal-regulated kinase 1/2 and stress-activated protein kinase/c-Jun NH2-terminal kinase in pancreatic islets by glucose and palmitate: possible involvement of ceramide. Pancreas, v. 38, n. 5, p. 585-592, 2009.

NOLAN, C. J. et al. Fatty Acid Signaling in the $\{$ beta $\}$-Cell and Insulin Secretion. Diabetes, v. 55, p. S16-23, 2006.

O'DONNELL, V. B.; SMITH, G. C.; JONES, O. T. Involvement of phenyl radicals in iodonium inhibition of flavoenzymes. Mol. Pharmacol., v. 46, n. 4, p. 778-785, 1994. 
OGAWA, T. et al. GPR40 gene Arg211His polymorphism may contribute to the variation of insulin secretory capacity in Japanese men. Metabolism, v. 54, n. 3, p. 296-299, 2005.

OKAMURA, N. et al. Relationship of protein phosphorylation to the activation of the respiratory burst in human neutrophils. Defects in the phosphorylation of a group of closely related 48-kDa proteins in two forms of chronic granulomatous disease. J. Biol. Chem., v. 263, n. 14, p. 6777-6782, 1988.

OLIVEIRA, H. R.; CURI, R.; CARPINELLI, A. R. Glucose induces an acute increase of superoxide dismutase activity in incubated rat pancreatic islets. Am. J. Physiol., v. 276, n. 2, pt 1, p. C507-510, 1999.

OLIVEIRA, H. R. et al. Pancreatic beta-cells express phagocyte-like NAD(P)H oxidase. Diabetes, v. 52, n. 6, p. 1457-1463, 2003.

OLOFSSON, C. S. et al. Palmitate stimulation of glucagon secretion in mouse pancreatic alpha-cells results from activation of L-type calcium channels and elevation of cytoplasmic calcium. Diabetes, v. 53, n. 11, p. 2836-2843, 2004a.

OLOFSSON, C. S. et al. Palmitate increases L-type Ca2+ currents and the size of the readily releasable granule pool in mouse pancreatic beta-cells. J Physiol, v. 557, n. Pt 3, p. 935-948, 2004b.

OPARA, E. C. et al. Effect of fatty acids on insulin release: role of chain length and degree of unsaturation. Am. J. Physiol., v. 266, n. 4, pt 1, p. E635-639, 1994.

PACLET, M. H. et al. NADPH oxidase of Epstein-Barr-virus immortalized B lymphocytes. Effect of cytochrome b(558) glycosylation. Eur. J. Biochem., v. 268, n. 19, p. 5197-5208, 2001.

PAN, Q. R. et al. Glucose, Metformin, and AICAR Regulate the Expression of G Proteincoupled Receptor Members in INS-1 beta Cell. Horm. Metab. Res., v. 41, n. 11, p. 799-804, 2009.

PAPPAN, K. L. et al. Pancreatic beta-cell lipoprotein lipase independently regulates islet glucose metabolism and normal insulin secretion. J. Biol. Chem., v. 280, n. 10, p. 9023-9029, 2005.

PARKER, H. E. et al. Nutrient-dependent secretion of glucose-dependent insulinotropic polypeptide from primary murine K cells. Diabetologia, v. 52, n. 2, p. 289-298, 2009. 
PFAFFL, M. W. A new mathematical model for relative quantification in real-time RT-PCR. Nucleic Acids Research, v. 29, n. 9, p. e45, 2001.

PI, J. et al. Reactive oxygen species as a signal in glucose-stimulated insulin secretion. Diabetes, v. 56, n. 7, p. 1783-1791, 2007.

PICINATO, M. C. et al. Soybean- and olive-oils-enriched diets increase insulin secretion to glucose stimulus in isolated pancreatic rat islets. Physiol. Behav., v. 65, n. 2, p. 289-294, 1998.

PRENTKI, M.; CORKEY, B. E. Are the beta-cell signaling molecules malonyl-CoA and cystolic long-chain acyl-CoA implicated in multiple tissue defects of obesity and NIDDM? Diabetes, v. 45, n. 3, p. 273-283, 1996.

PRENTKI, M.; MATSCHINSKY, F. M. Ca2+, cAMP, and phospholipid-derived messengers in coupling mechanisms of insulin secretion. Physiol. Rev., v. 67, n. 4, p. 1185-1248, 1987.

RAGAN, C. I.; BLOXHAM, D. P. Specific labelling of a constituent polypeptide of bovine heart mitochondrial reduced nicotinamide-adenine dinucleotide-ubiquinone reductase by the inhibitor diphenyleneiodonium. Biochem. J., v. 163, n. 3, p. 605-615, 1977.

RANDLE, P. J. et al. The glucose fatty-acid cycle. Its role in insulin sensitivity and the metabolic disturbances of diabetes mellitus. Lancet, v. 1, p. 785-789, 1963.

REMIZOV, O. et al. Palmitate-induced Ca2+-signaling in pancreatic beta-cells. Mol. Cell. Endocrinol., v. 212, n. 1-2, p. 1-9, 2003.

RHEE, S. G. Cell signaling. H2O2, a necessary evil for cell signaling. Science, v. 312, n. 5782, p. 1882-1883, 2006.

RHEE, S. G. et al. Intracellular messenger function of hydrogen peroxide and its regulation by peroxiredoxins. Curr. Opin. Cell Biol., v. 17, n. 2, p. 183-189, 2005.

ROTROSEN, D. et al. Cytochrome b558: the flavin-binding component of the phagocyte NADPH oxidase. Science, v. 256, n. 5062, p. 1459-1462, 1992. 
SALEHI, A. et al. Free fatty acid receptor 1 (FFA(1)R/GPR40) and its involvement in fattyacid-stimulated insulin secretion. Cell Tissue Res., v. 322, n. 2, p. 207-215, 2005.

SAN JOSE, G. et al. Insulin-induced NADPH oxidase activation promotes proliferation and matrix metalloproteinase activation in monocytes/macrophages. Free Radic. Biol. Med., v. 46, n. 8, p. 1058-1067, 2009.

SAWADA, F. et al. Differential effect of sulfonylureas on production of reactive oxygen species and apoptosis in cultured pancreatic beta-cell line, MIN6. Metabolism., v. 57, n. 8, p. 1038-1045, 2008.

SCHNELL, S.; SCHAEFER, M.; SCHOFL, C. Free fatty acids increase cytosolic free calcium and stimulate insulin secretion from beta-cells through activation of GPR40. Mol. Cell. Endocrinol., v. 263, n. 1-2, p. 173-180, 2007.

SCHONFELD, P.; WOJTCZAK, L. Fatty acids as modulators of the cellular production of reactive oxygen species. Free Radic. Biol. Med., v. 45, n. 3, p. 231-241, 2008.

SCHREY, M. P.; MONTAGUE, W. Phosphatidylinositol hydrolysis in isolated guinea-pig islets of Langerhans. Biochem. J., v. 216, n. 2, p. 433-441, 1983.

SHAPIRO, H. et al. Role of GPR40 in fatty acid action on the beta cell line INS-1E. Biochem. Biophys. Res. Commun., v. 335, n. 1, p. 97-104, 2005.

SHEPPARD, F. R. et al. Structural organization of the neutrophil NADPH oxidase: phosphorylation and translocation during priming and activation. J. Leukoc. Biol., v. 78, n. 5, p. 1025-1042, 2005.

SONG, F. et al. Synthesis and biological evaluation of 3-aryl-3-(4-phenoxy)-propionic acid as a novel series of G protein-coupled receptor 40 agonists. J Med Chem, v. 50, n. 12, p. 2807 2817, 2007.

SPECTOR, A. A.; FLETCHER, J. E.; ASHBROOK, J. D. Analysis of long-chain free fatty acid binding to bovine serum albumin by determination of stepwise equilibrium constants. Biochemistry (Mosc). v. 10, n. 17, p. 3229-3232, 1971.

SPECTOR, A. A.; HOAK, J. C. Letter: Fatty acids, platelets, and microcirculatory obstruction. Science, v. 190, n. 4213, p. 490-492, 1975. 
STEINBECK, M. J.; HEGG, G. G.; KARNOVSKY, M. J. Arachidonate activation of the neutrophil NADPH-oxidase. Synergistic effects of protein phosphatase inhibitors compared with protein kinase activators. J. Biol. Chem., v. 266, n. 25, p. 16336-16342, 1991.

STENEBERG, P. et al. The FFA receptor GPR40 links hyperinsulinemia, hepatic steatosis, and impaired glucose homeostasis in mouse. Cell Metab., v. 1, n. 4, p. 245-258, 2005.

STODDART, L. A.; BROWN, A. J.; MILLIGAN, G. Uncovering the pharmacology of the G protein-coupled receptor GPR40: high apparent constitutive activity in guanosine 5'-O-(3[35S]thio)triphosphate binding studies reflects binding of an endogenous agonist. Mol. Pharmacol., v. 71, n. 4, p. 994-1005, 2007.

SUMIMOTO, H. et al. Assembly and activation of the phagocyte NADPH oxidase. Specific interaction of the N-terminal Src homology 3 domain of p47phox with p22phox is required for activation of the NADPH oxidase. J. Biol. Chem., v. 271, n. 36, p. 22152-22158, 1996.

TALIOR, I. et al. Increased glucose uptake promotes oxidative stress and PKC-delta activation in adipocytes of obese, insulin-resistant mice. American Journal of Physiology Endocrinology \& Metabolism, v. 285, n. 2, p. E295-302, 2003.

TAN, C. P. et al. Selective small-molecule agonists of G protein-coupled receptor 40 promote glucose-dependent insulin secretion and reduce blood glucose in mice. Diabetes, v. 57, n. 8, p. 2211-2219, 2008.

THAMS, P.; CAPITO, K. Differential mechanisms of glucose and palmitate in augmentation of insulin secretion in mouse pancreatic islets. Diabetologia, v. 44, n. 6, p. 738-746, 2001.

TIKHONOVA, I. G. et al. Bidirectional, iterative approach to the structural delineation of the functional "chemoprint" in GPR40 for agonist recognition. J. Med. Chem., v. 50, n. 13, p. 2981-2989, 2007.

TSUBOUCHI, H. et al. Sulfonylurea as well as elevated glucose levels stimulate reactive oxygen species production in the pancreatic beta-cell line, MIN6-a role of NAD(P)H oxidase in beta-cells. Biochem. Biophys. Res. Commun., v. 326, n. 1, p. 60-65, 2005.

TURK, J.; WOLF, B. A.; MCDANIEL, M. L. The role of phospholipid-derived mediators including arachidonic acid, its metabolites, and inositoltrisphosphate and of intracellular $\mathrm{Ca} 2+$ in glucose-induced insulin secretion by pancreatic islets. Prog. Lipid Res., v. 26, n. 2, p. $125-$ $181,1987$. 
UCHIZONO, Y. et al. Expression of isoforms of NADPH oxidase components in rat pancreatic islets. Life Sci., v. 80, n. 2, p. 133-139, 2006.

UNGER, R. H. Lipotoxicity in the pathogenesis of obesity-dependent NIDDM. Genetic and clinical implications. Diabetes, v. 44, n. 8, p. 863-870, 1995.

VAISSIERE, C.; LE CABEC, V.; MARIDONNEAU-PARINI, I. NADPH oxidase is functionally assembled in specific granules during activation of human neutrophils. $\mathbf{J}$. Leukoc. Biol., v. 65, n. 5, p. 629-634, 1999.

VETTOR, R. et al. Loss-of-function mutation of the GPR40 gene associates with abnormal stimulated insulin secretion by acting on intracellular calcium mobilization. J. Clin. Endocrinol. Metab., v. 93, n. 9, p. 3541-3550, 2008.

WALLACH, T. M.; SEGAL, A. W. Analysis of glycosylation sites on gp91phox, the flavocytochrome of the NADPH oxidase, by site-directed mutagenesis and translation in vitro. Biochem. J., v. 321, n. 3, p. 583-585, 1997.

WARNOTTE, C. et al. Mechanisms of the stimulation of insulin release by saturated fatty acids. A study of palmitate effects in mouse beta-cells. Diabetes, v. 43, n. 5, p. 703-711, 1994.

WARWAR, N. et al. Dynamics of glucose-induced localization of PKC isoenzymes in pancreatic beta-cells: diabetes-related changes in the GK rat. Diabetes, v. 55, n. 3, p. 590-599, 2006.

WOLLHEIM, C. B.; SHARP, G. W. Regulation of insulin release by calcium. Physiol. Rev., v. 61, n. 4, p. 914-973, 1981.

WREDE, C. E. et al. Systematic analysis of the insulinotropic and glucagonotropic potency of saturated and monounsaturated fatty acid mixtures in rat pancreatic islets. Horm. Metab. Res., v. 39, n. 7, p. 482-488, 2007.

YADA, T.; HAMAKAWA, N.; YAEKURA, K. Two distinct modes of Ca2+ signalling by $\mathrm{ACh}$ in rat pancreatic beta-cells: concentration, glucose dependence and $\mathrm{Ca} 2+$ origin. $\mathbf{J}$ Physiol, v. 488, n. 1, p. 13-24, 1995.

YANG, M. et al. Sulfonylureas uncouple glucose-dependence for GPR40-mediated enhancement of insulin secretion from INS-1E cells. Mol. Cell. Endocrinol., v. 315, n. 1-2, p. 308-313, 2009. 
YEDOVITZKY, M. et al. Translocation inhibitors define specificity of protein kinase C isoenzymes in pancreatic beta-cells. J. Biol. Chem., v. 272, n. 3, p. 1417-1420, 1997.

ZAWALICH, W. S.; RASMUSSEN, H. Control of insulin secretion: a model involving Ca2+, cAMP and diacylglycerol. Mol. Cell. Endocrinol., v. 70, n. 2, p. 119-137, 1990.

ZENG, Q. et al. Endothelin-1 regulates cardiac L-type calcium channels via NAD $(\mathrm{P}) \mathrm{H}$ oxidase-derived superoxide. J. Pharmacol. Exp. Ther., v. 326, n. 3, p. 732-738, 2008.

ZHANG, $\mathrm{H}$. et al. Bimodal role of conventional protein kinase $\mathrm{C}$ in insulin secretion from rat pancreatic beta cells. J. Physiol. (Lond). v. 561, n. 1, p. 133-147, 2004.

ZHANG, M. et al. The Ca2+ dynamics of isolated mouse beta-cells and islets: implications for mathematical models. Biophys. J., v. 84, n. 5, p. 2852-2870, 2003.

ZHAO, H. et al. Superoxide reacts with hydroethidine but forms a fluorescent product that is distinctly different from ethidium: potential implications in intracellular fluorescence detection of superoxide. Free Radic. Biol. Med., v. 34, n. 11, p. 1359-1368, 2003.

ZHUANG, D. et al. Nitric oxide attenuates insulin- or IGF-I-stimulated aortic smooth muscle cell motility by decreasing H2O2 levels: essential role of cGMP. Am. J. Physiol. Heart Circ. Physiol., v. 286, n. 6, p. H2103-2112, 2004. 


\section{ANEXOS}

\section{ANEXO A - Trabalho referente ao estudo desenvolvido durante o doutorado}

Graciano MF, Santos LR, Curi R, Carpinelli AR. NAD $(\mathrm{P}) \mathrm{H}$ oxidase participates in the palmitate-induced insulin secretion by rat pancreatic islet. J. Cell Physiol. 2010 Sep 20. In press. 
ANEXO B - Trabalho referente ao estudo desenvolvido durante a Iniciação Científica e início do doutorado

Graciano MF, Nogueira TC, Carvalho CR, Curi R, Carpinelli AR. Palmitate activates insulin signaling pathway in pancreatic rat islets. Pancreas. 2009 Jul;38(5):578-84. 


\section{ANEXO C - Trabalhos publicados em colaboração}

Valle MM, Graciano MF, Rebelato E, Camporez JP, Akamine EH, Carvalho CR, Curi R, Carpinelli AR. NAD(P)H oxidase expression and activity in pancreatic islets from high fat diet induced obese rats. Pancreas. 2010. In press.

Morgan D, Rebelato E, Abdulkader F, Graciano MF, Oliveira-Emilio HR, Hirata AE, Rocha MS, Bordin S, Curi R, Carpinelli AR. Association of NAD(P)H oxidase with glucose-induced insulin secretion by pancreatic beta cells. Endocrinology. 2009 May;150(5):2197-201.

Nogueira TC, Graciano MF, Anhê GF, Curi R, Bordin S, Carpinelli AR. Short-term modulation of ERK1/2 and SAPK/JNK in pancreatic islets by glucose and palmitate: possible involvement of ceramide. Pancreas. 2009 Jul;38(5):585-92.

\section{Trabalho em elaboração}

Rebelato E, Mares-Guia TR, Graciano MF, Labriola L, Britto, LRG, Garay-Malpartida M, Curi R, Sogayar MC, Carpinelli AR. Control of Insulin Secretion by NAD(P)H Oxidase in Human Pancreatic Islets. 